UNIVERSIDADE DE SÃO PAULO

FACULDADE DE ECONOMIA, ADMINISTRAÇÃO E CONTABILIDADE

PROGRAMA DE PÓS-GRADUAÇÃO EM ADMINISTRAÇÃO

ESTRATÉGIAS DA COMUNICAÇÃO DAS MARCAS DO SETOR

FINANCEIRO BRASILEIRO NO FACEBOOK

Marcos Shigueru Suzuki

Orientador: Andres Rodriguez Veloso

SÃO PAULO 
Prof. Dr. Marco Antônio Zago

Reitor da Universidade de São Paulo

Prof. Dr. Adalberto Américo Fischmann

Diretor da Faculdade de Economia, Administração e Contabilidade

Prof. Dr. Roberto Sbragia

Chefe do Departamento de Administração

Prof. Dr. Moacir Miranda de Oliveira Junior

Coordenador do Programa de Pós-Graduação em Administração 
MARCOS SHIGUERU SUZUKI

\title{
ESTRATÉGIAS DA COMUNICAÇÃO DAS MARCAS DO SETOR FINANCEIRO BRASILEIRO NO FACEBOOK
}

Dissertação apresentada à Faculdade de Economia, Administração e Contabilidade da USP, como parte das exigências para a obtenção do título de Mestre em Ciências.

Área de Concentração: Marketing

Orientador: Prof. Dr. Andres Rodriguez Veloso

\begin{abstract}
Versão Corrigida
(versão original disponível na Biblioteca da Faculdade de Economia, Administração e Contabilidade)

SÃO PAULO
\end{abstract}


FICHA CATALOGRÁFICA

Elaborada pela Seção de Processamento Técnico do SBD/FEA/USP

Suzuki, Marcos Shigueru

Estratégias da comunicação das marcas do setor financeiro brasileiro no facebook / Marcos Shigueru Suzuki. - São Paulo, 2017.

$83 \mathrm{p}$.

Dissertação (Mestrado) - Universidade de São Paulo, 2017.

Orientador: Andres Rodrigues Veloso.

1. Estratégia da comunicação 2. Mídias sociais 3. Redes sociais 4. Facebook I. Universidade de São Paulo. Faculdade de Economia, Administração e Contabilidade. II. Título.

CDD -658.8 
"Os que se encantam com a prática sem a ciência são como os timoneiros que entram no navio sem timão nem bússola, nunca tendo certeza do seu destino".

(Leonardo da Vinci) 



\section{AGRADECIMENTOS}

Meus agradecimentos ao meu Orientador Prof. Dr. Andres Rodriguez Veloso que sempre me apoiou e me tranquilizou em momentos de incertezas. A Profa. Dra. Ana A. Ikeda que foi a primeira pessoa que tive contato na FEA e me deu os primeiros conselhos. A todos os meus professores no mestrado. Aos meus colegas João do Carmo, Luiz W. Tavares e Werner que compartilharam esses momentos intensos no mestrado. 



\section{RESUMO}

A comunicação entre as marcas e seus consumidores ocorre de maneira cada vez mais fragmentada. Hoje são múltiplas as mídias nas quais o consumidor pode ser impactado e as mídias sociais são as mais recentes e as que tem maior potencial de crescimento entre as utilizadas pelas marcas para acessar o consumidor. E entre as várias formas de mídias sociais, as redes sociais são as que tem maior destaque nos dias atuais. O Facebook é a maior entre todas as redes sociais alcançando mais de 1,9 bilhão de pessoas no mundo em 2017. Assim se torna importante entender como as marcas estão se comunicando com seus consumidores. A comunicação é uma condição essencial para o estabelecimento de relacionamento entre pessoas e marcas.

A partir da identificação dos elementos de comunicação mais utilizados pelas marcas é possível inferir quais são as estratégias utilizadas por elas e, se as estratégias são comuns ao setor pesquisado ou se há algumas diferenças entre elas. Escolheu-se para este estudo marcas do setor bancário que tivessem representatividade no Brasil. Os bancos foram escolhidos por pertencerem ao setor de serviços que representam mais de $60 \%$ do PIB do Brasil. Para a escolha das marcas se utilizou como critério o valor da marca através do ranking da consultoria Brand Finance das 500 marcas de bancos mais valiosas no mundo e a representatividade da marca no Facebook através da quantidade de fãs em sua brandpage e os Patrimônios Líquidos de acordo com dados do Banco Central do Brasil.

Palavras-chave: comunicação, mídias sociais, redes sociais, Facebook 


\section{SUMMARY}

Communication between brands and their consumers is increasingly fragmented. Today there are multiple media in which the consumer can be impacted and social media are the latest and the ones that have the greatest growth potential among those used by brands to access the consumer. And among the various forms of social media, social networks are the most prominent these days. Facebook is the largest of all social networks reaching more than 1.9 billion people worldwide by 2017. So it becomes important to understand how brands are communicating with their consumers. Communication is an essential condition for establishing relationships between people and brands.

From the identification of the communication elements most used by the brands it is possible to infer which are the strategies used by them and if the strategies are common to the researched sector or if there are some differences between them. We selected for this study brands of the banking sector that had representation in Brazil. Banks were chosen because they belong to the services sector, which represent more than $60 \%$ of Brazil's GDP. In order to choose the brands, the brand value was used as a criterion through the Brand Finance consulting ranking of the 500 most valuable brands of banks in the world and the brand's representation in Facebook through the number of fans in its brand page and the Net Equity according to data from Central Bank of Brazil.

Keywords: communication, social media, social networks, Facebook 
1. INTRODUÇÃO

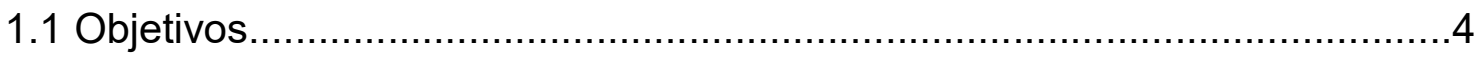

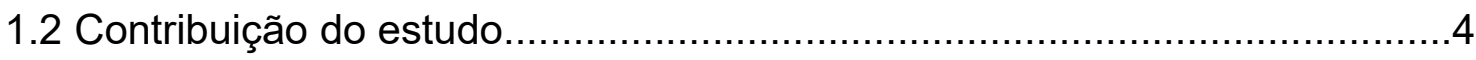

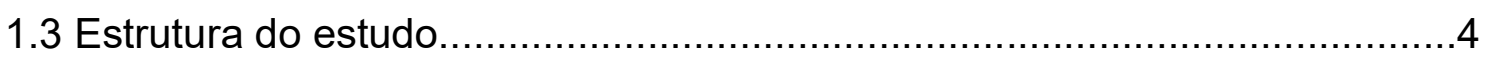

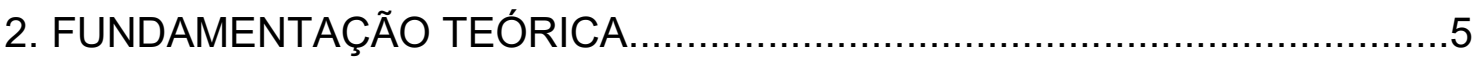

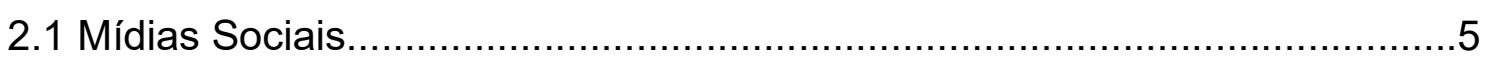

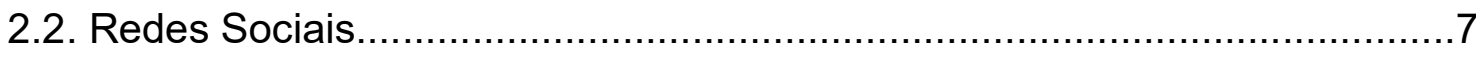

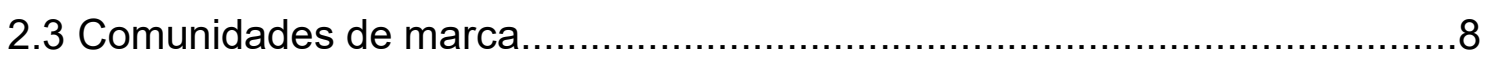

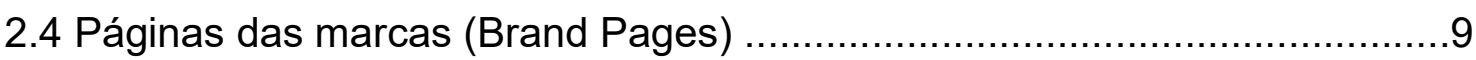

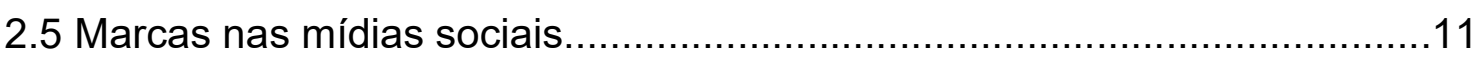

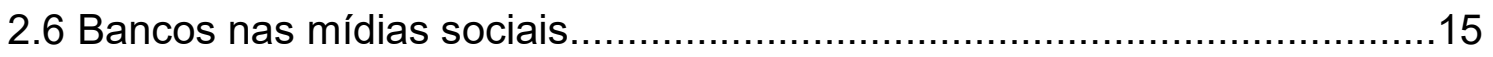

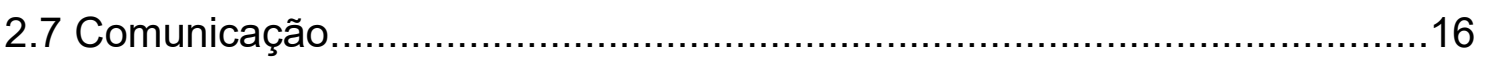

2.8 Comunicação das mídias tradicionais às mídias sociais............................17

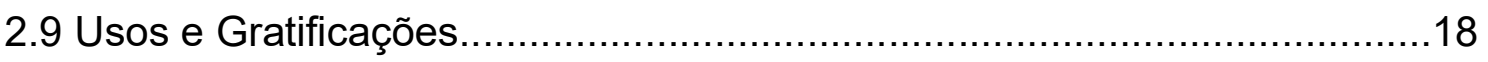

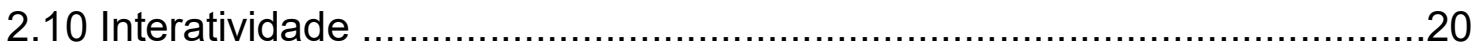

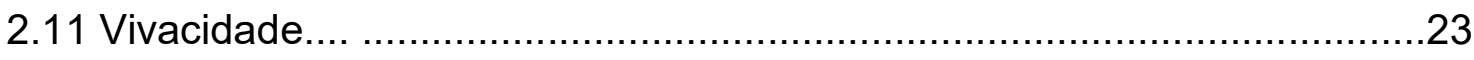

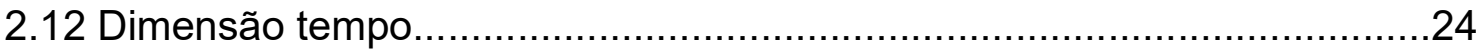

3. MÉTODO

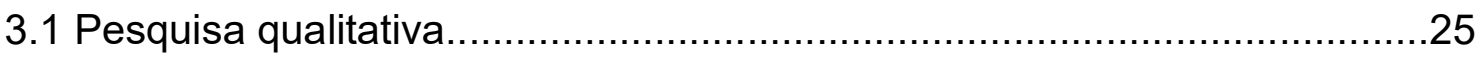

3.2 Definições importantes no planejamento da pesquisa................................25

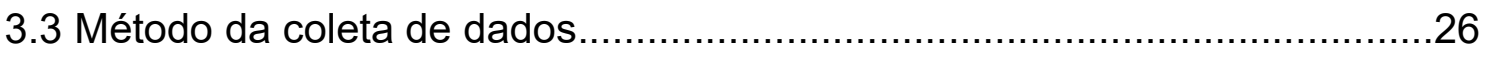

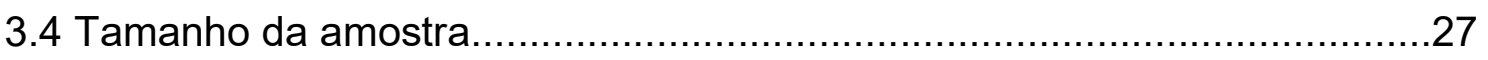

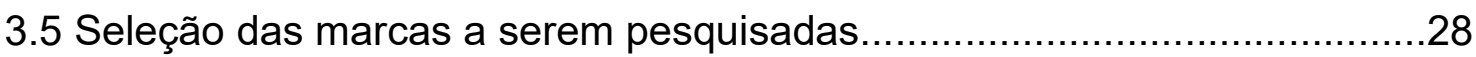

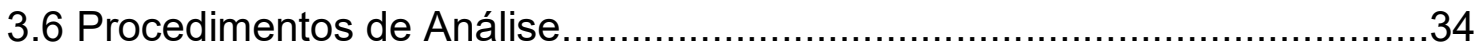

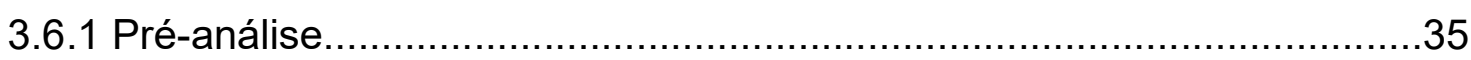

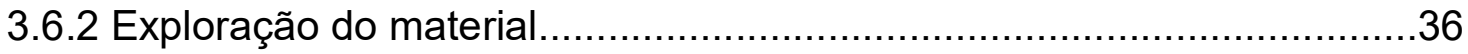

3.6.3 Tratamento do resultados, inferências e interpretação.............................40

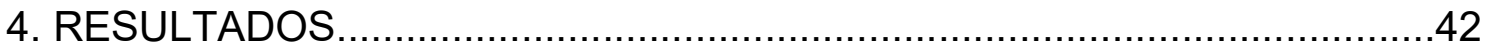

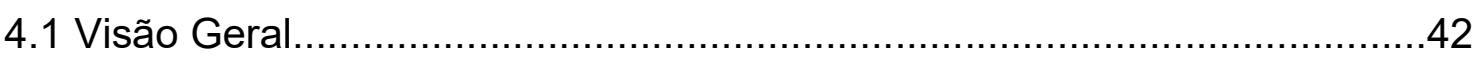

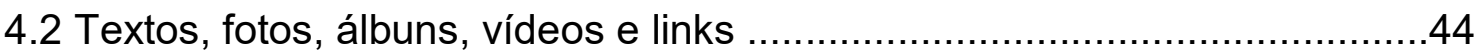




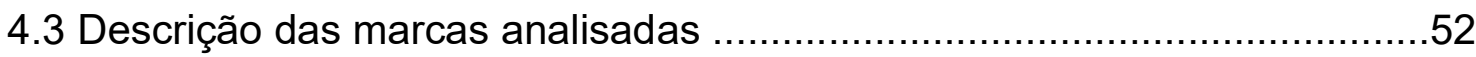

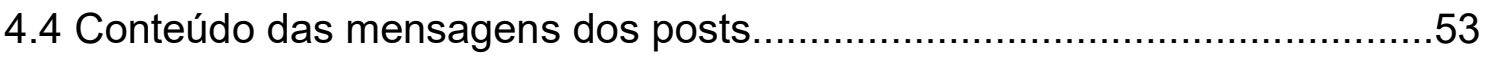

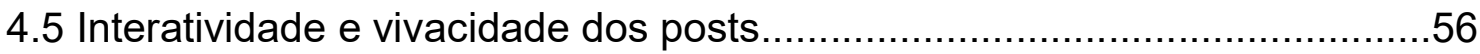

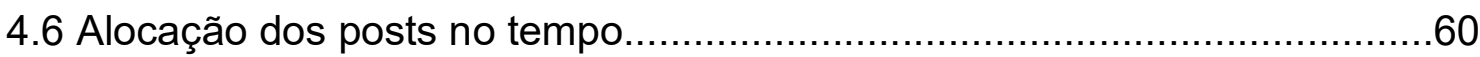

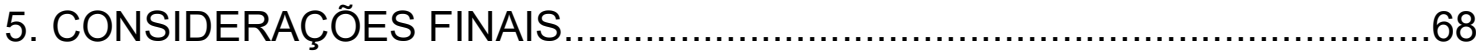

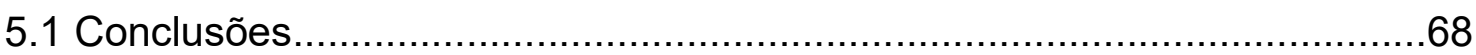

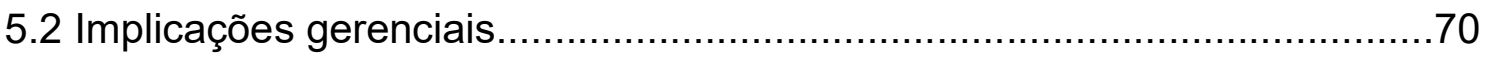

5.3 Limitações e recomendações futuras ....................................................

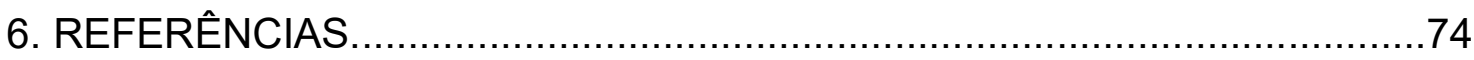

FIGURAS, QUADROS E TABELAS

Figura 1- Elementos do processo de comunicação ………...........................17

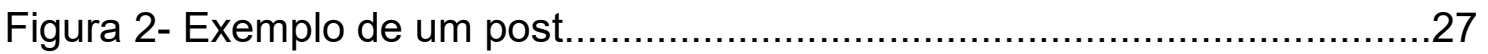

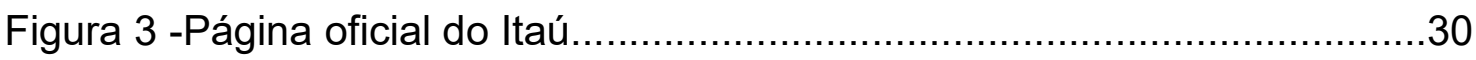

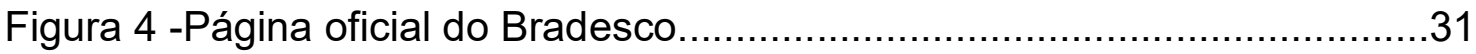

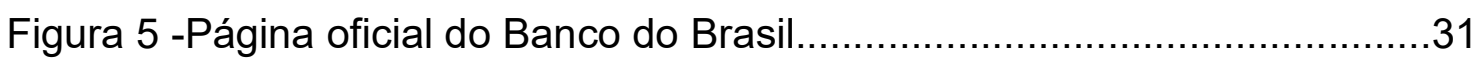

Figura 6 -Página oficial da Caixa Econômica Federal (CEF) ………................33

Figura 7 -Página oficial do Santander.......................................................33

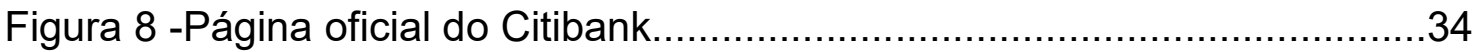

Figura 9 -Fluxo de análise de conteúdo proposto por Bardin (2009) ..............41

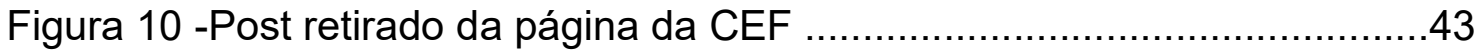

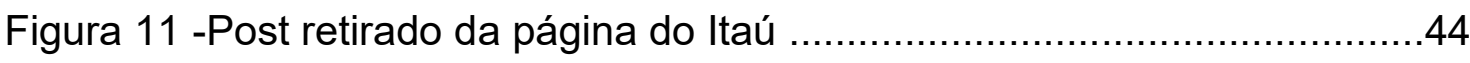

Figura 12 -Exemplo de frase de ação seguida de link ..................................46

Figura 13 -Texto junto com atualização da foto da capa .................................48

Figura 14 -Celebração pela conquista do ouro............................................49

Figura 15 -Post do BB fixado do dia 31/08/16 e permanecia fixado em

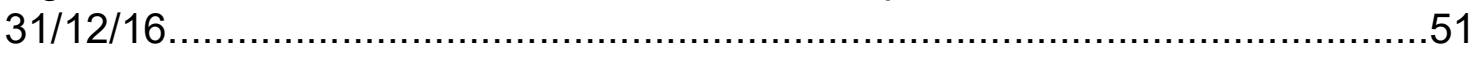

Figura 16 -Post fixado de entretenimento................................................52

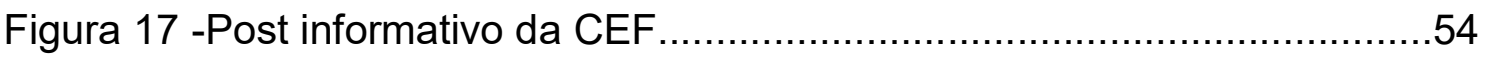

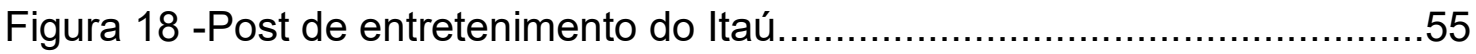




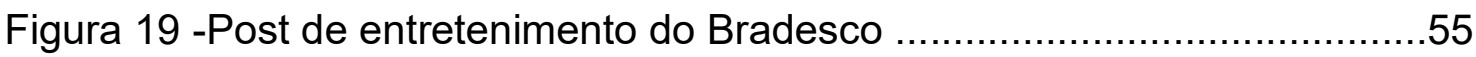

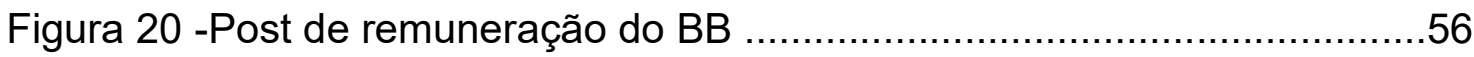

Figura 21 -Post de vídeo do Itaú com texto e hashtag ...................................58

Figura 22 -Post de vídeo sem som do Bradesco com texto e hashtag..............59

Figura 23 -Post de foto do BB com texto e hyperlink ....................................59

Figura 24 -Post de álbum do Citibank com texto e hashtag..............................60

Figura 25 -Post do Bradesco no domingo (dia de encerramento das olimpíadas)

Figura 26 -Média de dias para publicar um post por mês e marca .63

Figura 27 -Representação ilustrativa das marcas com base na interatividade / vivacidade $\mathrm{x}$ consistência na frequência de postagens e interatividade / vivacidade $\mathrm{x}$ tipos de conteúdo.

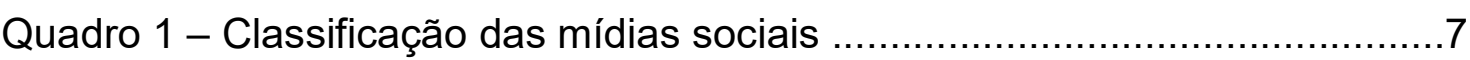

Quadro 2 - Categorias iniciais previstas pelo autor .....................................39

Quadro 3 - Categorias finais criadas pelo autor ..........................................40

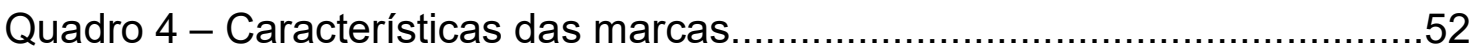

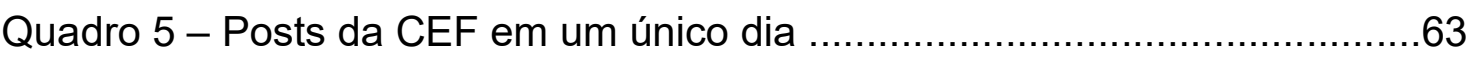

Quadro 6 - Síntese das estratégias das marcas..........................................65

Tabela 1 - As 10 marcas de bancos mais valiosas na América Latina .............28

Tabela 2 - As 10 marcas de bancos por Patrimônio Líquido no Brasil ..............29

Tabela 3 - Quantidade de fãs dos bancos no Facebook ...............................29

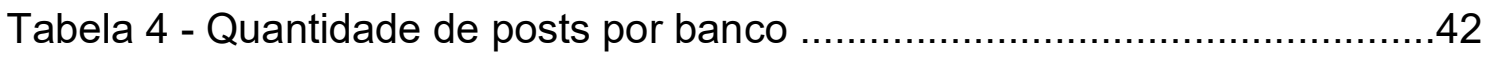

Tabela 5 - Quantidade de posts retirados por banco .....................................43

Tabela 6 - Evolução da quantidade de fãs das marcas no Facebook …….......44

Tabela 7 - Posts com elementos de interatividade / vivacidade ......................45

Tabela 8 - Posts por tipos de elementos de interatividade / vivacidade.............46

Tabela 9 - Quantidade de elementos de interatividade/ vivacidade no mesmo

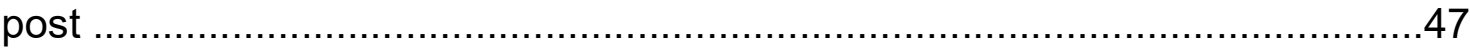

Tabela 10 - Tipo de post sem interatividade ......................................47 
Tabela 11 - Tipos de conteúdo

Tabela 12 - Frequência de posts por dia da semana ...................................49

Tabela 13 - Frequência de posts por período ...........................................50

Tabela 14 - Frequência dos posts mensal.................................................50

Tabela 15 - Posts fixados no topo da página ………………………...........

Tabela 16 - Posts fixados no topo da página por tipo de conteúdo ................51

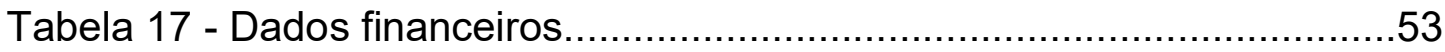

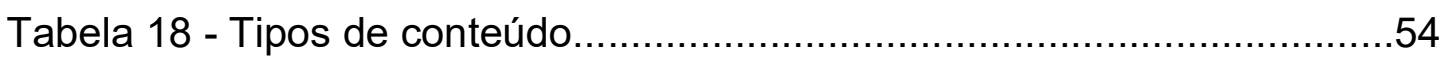

Tabela 19 - Posts com elementos de interatividade / vivacidade .................57

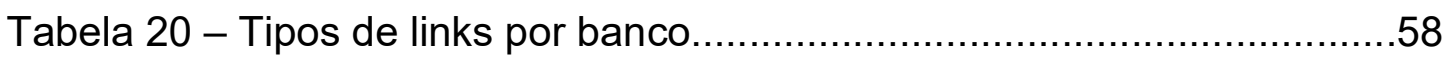

Tabela 21 - Quantidade de tipos de links por post e marca...........................60

Tabela 22 - Frequência de posts por período..............................................61

Tabela 23 - Frequência de posts por dia da semana....................................61

Tabela 24 - Frequência de posts por mês...................................................62 


\section{INTRODUÇÃO}

A comunicação das marcas com os seus diversos públicos de interesse sem dúvida é uma das ações mais importantes e complexa que uma marca tem que lidar e que em muitas vezes não logram sucesso. O sucesso depende de vários fatores como a natureza da mensagem, a interpretação que a audiência terá dela e o ambiente no qual ela é recebida (Belch \& Belch, 2014; Kotler \& Keller, 2006; Schramm \& Roberts, 1971)

No mundo atual a quantidade de mensagens que um consumidor é impactado (Kotler \& Keller, 2006; Neumeier, 2009) e a quantidade de meios pelos quais ele pode ser alcançado é cada vez maior (Crescitelli \& Shimp, 2012). Hoje um consumidor pode ser alcançado por diversos tipos de meios sejam eles tradicionais como televisão, jornal, revista, rádio ou alternativos como mídias sociais, advertgaming entre outros (Crescitelli \& Shimp, 2012)

Entre os diversos meios que o consumidor tem acesso, um que tem se destacado e com rápido crescimento são as mídias sociais (Effing \& Spil, 2016) e entre estas, as redes sociais que se tornaram um fenômeno nos últimos 10 anos, atraindo usuários de diferentes partes do mundo, com diferentes interesses e que se comportam de maneira distinta. Este fenômeno foi alavancado fortemente pela melhor qualidade e maior acesso à internet e ao desenvolvimento de tecnologias que permitiram o acesso a elas por meio de diferentes dispositivos. Isso foi determinante para que o canal de comunicação de marketing evoluísse a partir da mídia impressa, para o canal eletrônico para a mídia social no ciberespaço (Ab Hamid, Razak, Akhir, \& Cheng, 2009). O primeiro site de rede social reconhecível foi lançado em 1997. O SixDegrees.com permitia aos usuários criar perfis, listar os seus amigos e, a partir de 1998, surfar as listas de amigos (Boyd \& Ellison, 2007). Dentro de um curto espaço de tempo, esses sites se tornaram um vício para os jovens, pois Ihes deram a oportunidade e a plataforma para expressar seus sentimentos e emoções na sociedade (Saxena \& Khanna, 2013). É inegável o fato de que as redes sociais fazem parte da vida de boa parte da população mundial. O Facebook, atualmente é o maior serviço de rede social de alcance global, com 1,9 bilhões de usuários ativos (Statista, 2017). Isto representa aproximadamente $25 \%$ da população mundial de 7,5 bilhões de pessoas (PopulationPyramid, 2017). No Brasil, o Facebook 
possui 102 milhões de usuários (Sumares, 2016), representando aproximadamente 50\% da população brasileira de 206 milhões (G1, 2016). A importância do Facebook pode ser vista pelo seu valor de mercado e de sua marca. Facebook é avaliado em US $\$ 444,9$ bilhões (Financial Times, 2017). Sua marca, por sua vez, vale US\$129,8 bilhões e é a $5^{\text {a }}$ mais valiosa do mundo de acordo como o Ranking das 100 marcas globais mais valiosas de 2017 da empresa Kantar Millward Brown. E entre as plataformas de mídias sociais é a mais utilizada (Arenas-Gaitan, Rondan-Cataluña, \& Ramírez-Correa, 2013).

Com a popularidade das redes sociais (Luarn, Lin, \& Chiu, 2015), as empresas começaram a lançar mão das ferramentas de marketing para tentar alavancar o brand equity de suas marcas (Bruhn, Schoenmueller, \& Schäfer, 2012) e, eventualmente, suas vendas, por entenderem que as redes sociais poderiam ser um excelente canal de relacionamento empresa-consumidor. Em pouco tempo as mídias sociais foram utilizadas com diferentes objetivos de marketing tais como branding, pesquisa, CRM, serviço e promoção de vendas (Ashley \& Tuten, 2015). Nisar e Whitehead (2016) identificaram em seu estudo que indivíduos declararam que seguem as marcas nas mídias sociais porque eles gostam das marcas e estão mais propensos a comprar produtos e serviços de marcas que eles seguem (Nisar \& Whitehead, 2016).

Para as marcas uma das grandes vantagens de estar presentes no universo das redes sociais é a resposta imediata dos resultados de suas comunicações (posts) e a capacidade de interação com os usuários. Além disso, no mundo digital o custo mais acessível (Bonsón Ponte, Carvajal-Trujillo, \& EscobarRodríguez, 2015; Saxena \& Khanna, 2013) aliado ao fato de que as comunicações podem ser direcionadas com maior precisão a cada um dos públicos-alvo dos anunciantes, tornam esse meio cada vez mais atrativo.

Stevenson(2010) contextualiza as vantagens do Facebook:

[...]aproveitando as informações do perfil de um usuário, bem como a enorme quantidade de informação pessoal que normalmente terá disponível em sua página pessoal, o Facebook torna possível que as marcas atinjam grupos de pessoas em um nível granular. Então ao invés de segmentar grupos com base na demografia simples e tradicionais, tais como idade, localização ou gênero, um anunciante pode usar as informações para ir tão profundo como a segmentação de consumidores em suas preferências pessoais, seja por seu filme, música ou programa de TV favorito. (p.15) 
A popularização das mídias digitais pode ser percebida pelo crescimento do investimento em propaganda nesse meio (Saxena \& Khanna, 2013). De acordo com projeções de investimento em propaganda mundial para 2018 publicadas pelo site Statista, o meio digital terá a maior participação do investimento em propaganda mundial em 2018, superando a TV com respectivamente $33 \%$ e $32 \%$. Em 2013 a participação do investimento em propaganda no meio digital e na TV foi de $31 \%$ e $25 \%$, respectivamente.

Ao mesmo tempo, a academia começou a demonstrar o interesse por esse fenômeno e passou a aborda-lo sob diferentes perspectivas. Diversos estudos foram feitos mostrando o interesse do mundo acadêmico sobre o assunto. Cho e Khang (2006) analisaram diversos estudos relacionados a internet nos quinze principais jornais de comunicação, marketing e propaganda. Tomasello, Lee, e Baer (2009) analisaram estudos endereçando as tecnologias digitais e de internet e acharam que as pesquisas de novas mídias têm crescido de maneira sustentável dentro da disciplina de comunicação. O estudo de Khang, Ki, e Ye (2012) mostra o interesse crescente de pesquisas à respeito de mídias sociais em jornais de propaganda, comunicação, marketing e relações pública no período de 1997 a 2010. Porém, quando o assunto são as comunidades de marcas dentro do Facebook (foram criadas em 2007) esse ainda é um tópico recente e pouco explorado. De acordo com Shi, Chen, e Chow (2016), as páginas das marcas das companhias nas mídias sociais, tem recebido pouco atenção ou como colocado por outros autores, a estratégia de conteúdo nas comunidades de marca tem sido pouco estudada (Chauhan \& Pillai, 2013, Kumar, 2015; Swani, Milne, Brown, Assaf, \& Donthu, 2017). Por fim, Celebi (2015) atesta ainda que não há muita pesquisa no campo das motivações da propaganda no Facebook. 


\subsection{Objetivos}

O objetivo deste trabalho é compreender a estratégia de comunicação das páginas dos bancos no Facebook no mercado brasileiro.

\subsection{Contribuições do estudo}

Este estudo pretende colaborar para a ampliação e compreensão sobre a estratégia de comunicação das marcas nas mídias sociais, mais especificamente de bancos no mercado brasileiro. Do ponto de vista teórico, este trabalho contribui ao aplicar a teoria de comunicação sob a óptica das mídias sociais ressaltando os conceitos de interatividade e vivacidade.

\subsection{Estrutura do estudo}

Para atingir o propósito, este estudo está estruturado nas seguintes partes:

Primeiramente será apresentada a fundamentação teórica que será a base para desenvolvimento desta pesquisa, separada pelos tópicos comunicação, mídias sociais, usos e gratificação, interatividade e vivacidade. Em seguida, colocará o foco na discussão do método proposto, através das diretrizes para o plano de coleta, categorização, codificação e análise de dados.

Por fim, a apresentação dos resultados da pesquisa empírica, desde a descrição dos dados coletados até análise dos resultados, finalizando com as conclusões do estudo, implicações gerenciais, limitações e sugestões para futuros estudos. 


\section{FUNDAMENTAÇÃO TEÓRICA}

Esta revisão da literatura é importante, pois fornece suporte teórico aos tópicos abordados neste trabalho. Para tanto, dividiu-se este item em partes distintas para um maior aprofundamento sobre o entendimento de alguns conceitos: comunicação e os aspectos que devem ser levados em consideração para alcançar a sua eficácia e mídias sociais e seus desdobramentos.

\subsection{Mídias sociais}

Para Kaplan e Haenlein (2010), mídias sociais podem ser definidas como "um grupo de aplicações baseadas na internet que foi construída sobre as fundações tecnológica e ideológica da Web 2.0 e que permite a criação e troca de conteúdo gerado pelo usuário". Entre os tipos de aplicações, os autores citam os projetos colaborativos como Wikipedia e Blogs, comunidades de conteúdo (ex: Youtube), sites de redes sociais (ex: Facebook), virtual games (ex.: Word of Warcraft) e mundos virtuais (ex: Second Life). Com aplicações surgindo a cada momento os autores criaram uma classificação para definir cada tipo de aplicação. Usaram como critérios de classificação as teorias trabalhadas no campo das pesquisas de mídia (presença social e riqueza da mídia) para avaliar o meio e as teorias de processo social (auto-apresentação e auto-divulgação) para a exposição dos usuários. O quadro 1 mostra um exemplo de classificação das mídias sociais.

Em relação a teoria de presença social os autores citam Short, William e Christie (1976) que atestam que a mídia varia em função do grau de presença social que emerge na comunicação entre duas pessoas. Presença social é definida pelos autores como "contato físico, visual e acústico que pode ser alcançado". Uma definição mais atual é o Fortin e Dholakia (2005) que diz que presença social representa o grau no qual um meio transmite a presença percebida dos participantes em uma comunicação em uma troca de duas vias.

A presença social é influenciada por dois aspectos: intimidade e imediaticidade do meio. Intimidade se refere a comunicação pessoal ou mediada. Pessoal, onde duas pessoas, por exemplo, estariam conversando, frente a frente e, mediado, por exemplo, quando uma pessoa conversa pelo computador. Já a 
imediaticidade do meio: comunicação assíncrona, como por exemplo email ou síncrona com chats ao vivo. Dessa forma, quanto maior o grau de presença social maior será a influência que cada pessoa terá sobre a outra em uma comunicação (Kaplan \& Haenlein, 2010).

Vivacidade é uma das principais dimensões para determinar a telepresença. De acordo com Steuer (1992) a telepresença pode ser definida como "experiência de presença em um ambiente através de um meio de comunicação". Comparado com um ambiente não mediado, as pessoas em um ambiente mediado não podem diretamente sentir, tocar, saborear ou cheirar um objeto. Ao invés, eles se baseiam no meio para criar a sensação de estar presente e vivenciando a experiência, isto é, uma representação de uma experiência direta (Steuer, 1992).

A teoria da riqueza da mídia (Daft \& Lengel, 1986) é baseada na premissa que o objetivo de qualquer comunicação é a resolução da ambiguidade e da redução da incerteza. A riqueza da mídia varia na medida em que mais informações são transmitidas em um dado intervalo de tempo. Quanto mais rico for essa transmissão, menores as ambuiguidades e as incertezas. Uma das formas de enriquecer a mídia é através do conceito da vivacidade (Daft \& Lengel, 1986) que é muito empregada nos estudos envolvendo as mídias sociais.

De acordo com Fortin e Dholakia (2005), mensagens vívidas com altos níveis de informação sensorial podem simular presença social e despertar a atenção. Portanto, telepresença ela simula uma presença social.

Em relação as dimensões sociais, o conceito de auto-apresentação, de acordo com Kaplan e Haenlein (2010) citando Goffman (1959), se refere ao "desejo que as pessoas têm de controlar as impressões que as outras pessoas fazem dela em uma interação social" p.62.

Auto-divulgação se refere a exposição de informações pessoais de maneira consciente ou inconsciente no intuito de passar uma imagem que a pessoa gostaria de ser percebida. 


\begin{tabular}{|c|c|c|c|c|}
\hline & \multicolumn{3}{|c|}{ Presença Social / Riqueza da mídia } \\
\hline & & Baixo & Médio & Alto \\
\hline \multirow{2}{*}{$\begin{array}{c}\text { Exposição do } \\
\text { Usuário }\end{array}$} & Alto & Blogs & $\begin{array}{l}\text { Sites de redes sociais } \\
\quad \text { (ex.: Facebook) }\end{array}$ & $\begin{array}{l}\text { Mundos Virtuais Sociais } \\
\text { (ex.: Second Life) }\end{array}$ \\
\hline & Baixo & $\begin{array}{c}\text { Projetos } \\
\text { colaborativos } \\
\text { (ex.: Wikipedia) }\end{array}$ & $\begin{array}{c}\text { Comunidades de } \\
\text { conteúdo (ex.: } \\
\text { YouTube) }\end{array}$ & $\begin{array}{c}\text { Mundos de jogos } \\
\text { virtuais (ex.: World of } \\
\text { Warcraft) }\end{array}$ \\
\hline
\end{tabular}

Quadro 1 - Classificação das mídias sociais. Adaptado de Kaplan e Haenlein (2010)

A seguir detalhes sobre redes sociais um dos tipos de mídias sociais mais importantes da atualidade.

\subsection{Redes Sociais}

De acordo com a definição de Boyd e Ellison (2007) redes sociais são:

[...] Serviços baseados na web que permitem aos indivíduos a (1) construir um perfil público ou semi-público dentro de um sistema limitado, (2) articular uma lista de outros usuários com quem eles compartilham uma conexão, e (3) ver e percorrer sua lista de conexões e aqueles feitos por outros dentro do sistema. A natureza e nomenclatura dessas conexões podem variar de local para local. (p.211)

Para Kaplan e Haenlein (2010) os sites de redes sociais são: "aplicativos que permitem aos usuários se conectar criando perfis de informações pessoais, convidando amigos e colegas a ter acesso a esses perfis e enviando e-mails e mensagens instantâneas entre si” (p.63).

Os sites de redes sociais complementam a rede de relacionamentos presentes no mundo off-line, fornecendo uma plataforma que permite a comunicação ativa entre amigos e também se envolve em uma forma de observação passiva de notícias sociais. Apesar de os sites de redes sociais serem frequentemente concebidos para serem amplamente acessíveis, muitos atraem populações homogêneas inicialmente. Por esse motivo, não é raro encontrar grupos usando sites para se juntar em comunidades por nacionalidade, idade, nível de escolaridade ou por outros fatores que normalmente segmentam a sociedade 
(Boyd \& Ellison, 2007). A visibilidade de um perfil varia conforme o local e de acordo com o critério do usuário. No caso do Facebook, por exemplo, por padrão, os usuários que fazem parte da mesma "rede" podem ver os perfis uns dos outros, a menos que um proprietário de perfil decidiu negar permissão para aqueles em sua rede (Boyd \& Ellison, 2007). As redes sociais como o Facebook são projetadas para maximizar as trocas sociais. Em contraste, as classificações e sites de avaliação são projetados para comunicações unidirecionais do post para o leitor (Schweidel \& Moe, 2014).

O crescimento contínuo das redes sociais atraiu o interesse de empresas para transmitir informações de seus produtos e mensagens de marketing para seus consumidores (Luarn et al., 2015). Diversas companhias já estão usando os sites de redes sociais para criar as suas comunidades de marca (Muniz \& O'Guinn, 2001). A seguir, detalhes sobre comunidades de marca.

\subsection{Comunidades de marca}

Uma comunidade de marcas é "uma comunidade especializada, não geograficamente vinculada, baseada em um conjunto estruturado de relações sociais entre admiradores de uma marca " (Muniz \& O'Guinn, 2001). Portanto, as comunidades de marcas podem ser entendidas como uma forma de rede social voltada para uma marca ou como explicitado por Costa (2005), "o conceito de redes sociais responde a uma compreensão da interação humana mais amplo que o da comunidade" (p.246).

As comunidades de marcas foram originalmente criadas no mundo offline e posteriormente com o advento da internet começaram a se estabelecer no mundo online também como, por exemplo, em fóruns de discussão e, mais recentemente, em sites de redes sociais como Facebook (Chauhan \& Pillai, 2013). As comunidades de marcas criadas no meio online, denominadas comunidades de marcas virtuais, podem ser classificadas quanto a sua criação em criadas pelos membros ou criados pela companhia (Porter, 2004).

Para Smith e Yongjian (2012), pesquisas anteriores descobriram que o Twitter e o Facebook oferecem oportunidades colaborativas entre empresas e clientes 
para gerar sentimento positivo e visibilidade para as marcas. Portanto, recomenda-se que os profissionais de marketing criem um espaço no qual as comunidades de marcas possam se formar e ser mantidas recompensando os clientes e, interagindo e respondendo as questões do consumidor (Smith et al., 2012). Para Schau, Muñiz e Arnould (2009), as páginas de marca são usadas principalmente como uma ferramenta de comunicação, mas pesquisas em comunidades de marcas sugerem que mais valor pode ser criado no cultivo de ambientes comuns.

Ainda sobre comunidades, o seu tamanho é elemento chave para compreender o efeito da identificação na lealdade e no boca-a-boca. Pequenas e grandes comunidades funcionam de maneira diferentes (Scarpi,2010). Dessa forma, os profissionais de marketing devem levar esse fator também em consideração na hora de criar as suas estratégias.

\subsection{Páginas das marcas (Brand pages)}

O Facebook é um site de redes sociais multifuncional, estabelecido em 2004. Os usuários podem criar seu próprio perfil, curtir, comentar ou compartilhar conteúdo e ler conteúdo de amigos, organizações e celebridades. O conteúdo pode incluir texto, vídeo, imagens, áudio e jogos (Hollebeek et al., 2014). Os consumidores usam o Facebook para acompanhar a vida das pessoas, "curtir" marcas e construir capital social em seu grupo social (Smith et al., 2012). Para os profissionais de marketing, o Facebook oferece oportunidades para colaborar com os consumidores, proporcionar um espaço para as conversas entre empresas e consumidores e consumidores, e uma oportunidade para aumentar a visibilidade e o sentimento positivo em torno da marca (Smith et al., 2012).

As Brand pages são comunidades de marcas criadas pelas organizações dentro dos domínios do Facebook, a maior rede social do mundo. De acordo com Rosenthal e Brito (2017) em 2007, as primeiras páginas do Facebook para marcas, empresas, filmes, artistas e equipes esportivas foram criadas para dar a essas instituições uma nova ferramenta para criar um relacionamento bidirecional com seus consumidores. Originalmente chamadas de páginas de fãs, são uma plataforma que "permite que a marca esteja presente, crie uma 
comunidade em torno de seus usuários e crie valor econômico" Segundo os autores, em 2017, as páginas da marca continuam sendo uma das ferramentas que o Facebook oferece para que as empresas atinjam clientes atuais e potenciais e promovam seus produtos e serviços.

As marcas compartilham mensagens, que são referidas como "publicações" (posts) em sua Página, com o intuito de desenvolver o relacionamento, 0 engajamento com a marca (Chauhan, \& Pillai, 2013; Rosenthal \& Brito, 2017). Estes posts podem aparecer na Newsfeed (mural de notícias) dos membros da sua comunidade (Chauhan, \& Pillai, 2013; Sabate, Berbegal-Mirabent, Cañabate, \& Lebherz, 2014). As marcas usam o mural de notícias para apresentar novas informações sobre produtos, promoções ou conteúdo de interesse do membro (Rosenthal \& Brito, 2017).

Os membros podem interagir com o post, "curtindo", "compartilhando" ou "comentando" (Sabate et al., 2014). As interações ativas de um cliente com uma empresa, com clientes potenciais e com outros clientes, sejam eles de natureza transacional ou não, podem ser definidas como "Engajamento do cliente" (Chauhan, \& Pillai, 2013). Outros autores utilizam o termo "Engajamento online" com o mesmo sentido. Engajamento da marca do consumidor tbm é utilizado nas mídias sociais (Hollebeek et al, 2014). Alguns autores utilizam como métrica de engajamento a quantidade de curtidas, comentários ou compartilhamento de um post.

As grandes marcas atuam de maneira ativa nas redes sociais. As dez páginas de marcas mais populares do Facebook, com mais de 15 milhões de membros, postavam uma média de 1,7 posts por dia (Zarrella, 2009). Além disso, o ato de publicamente "Curtir" algo por meio do qual os usuários são capazes de articular suas personalidades auto percebidas tem grande potencial para projetar o perfil de utilização dos consumidores com o intuito de segmentar e orientar a oferta de produtos (Croft, 2013).

As páginas de marca nas mídias sociais são uma ótima maneira de aumentar o número de consumidores em torno de uma marca, mas pode ser um desafio manter os fãs envolvidos e voltar para ver o conteúdo atualizado (Rosenthal \& Brito, 2017). De acordo com alguns estudos, marcas com mais de 500 mil fãs no 
Facebook viram o alcance orgânico cair para aproximadamente $2 \%$ de sua base (Delo, 2014).

A multiplicação de conteúdo no Facebook é uma das razões pelas quais o alcance orgânico das grandes marcas caiu significativamente desde 2013 (Constine, 2014; Delo, 2014). Há muito mais conteúdo do que o tempo para consumi-lo. Em média, 1.500 histórias poderiam aparecer no feed de notícias sempre que alguém se logar. Pessoas com muitos amigos ou que curtem muitas páginas poderiam ter até 15.000 histórias em potencial a cada acesso. $O$ algoritmo de feed de notícias do Facebook escolhe aproximadamente 300 histórias com base em diversos fatores relativos a cada usuário (Boland, 2014).

\subsection{Marcas nas mídias sociais}

As mídias sociais são um desafio para as empresas em um cenário onde clientes e funcionários as adotaram de forma massiva (Effing \& Spil, 2016). Onde existem diversas plataformas e formas de comunicação entre organizações e os consumidores para interação (Smith et al., 2012). Elas são um canal de comunicação de duas vias entre organizações e consumidores, que já faz parte do dia a dia dos consumidores (Sorescu, Frambach, Singh, Rangaswamy, \& Bridges, 2011). Consumidores exigem das empresas nas mídias sociais, os mesmos níveis de interatividade que elas possuem com outros usuários (Trainor, Andzulis, Rapp, \& Agnihotri, 2014). Esta interatividade bidirecional é um dos elementos chaves que definem as mídias sociais (Stevenson, 2010; de Vries, Gensler, \& Leeflang, 2012; Farshid, Plangger, \& Nel, 2011; Labrecque, 2014; Laroche, Habibi, Richard, \& Sankaranarayanan, 2012), mídia on-line (Liu \& Shrum, 2002), ou novas mídias como descrita por Fortin e Dholakia (2005).

Em uma perspectiva mais ampla, as mídias sociais através dessa interatividade de via dupla, oferecem uma plataforma para as organizações manterem um diálogo contínuo, em tempo real, com clientes e clientes em potencial, potencializando relacionamentos de longo prazo (Farshid et al., 2011; Laroche et al., 2012) e engajamento com os consumidores (Farshid et al., 2011). 
Para Stevenson, (2010) manter conversas com seus consumidores nas mídias sociais é estratégico para as marcas. O uso das mídias sociais permite as organizações desenvolvimento de conversas com seus consumidores, conquista de novos consumidores, influenciar a percepção sobre a credibilidade e reputação das marcas (Farshid et al.,2011), criar associações favoráveis a marca (Berry et al., 2010), aumentar a consciência e o gosto pelas marcas (Ashley \& Tuten, 2015) e construção de comunidades de marcas (Scarpi,2010).

Porém, as organizações ainda estão se esforçando para implementar as mídias sociais em suas empresas. Apenas disponibilizar as mídias sociais sem uma estratégia pode ser considerado um desperdício de tempo e recursos organizacionais (Effing \& Spil, 2016). Acima de tudo, as empresas precisam considerar formas criativas de usar a Internet e outras tecnologias de informação para fortalecer a confiança dos clientes nelas e fortalecer seu relacionamento com os clientes (Berry, Bolton, Bridges, Meyer, Parasuraman, \& Seiders, 2010).

Para Hanafizadeh (2012) os anunciantes comunicam, relacionam e influenciam usuários online para promover tanto lembrança quanto preferência de marca de um modo customizado e personalizado e, assim posicionar a marca e diminuir o tempo necessário para tomar uma decisão de compra. Para Croft (2013) em mercados de consumo (B2C), muitos consumidores usam o botão "Curtir" para expressar a preferência por uma marca, embora em alguns casos, essa ação seja apenas aspiracional em relação à marca, em vez de predizer decisões de consumo (Croft, 2013).

Para Saxena e Khanna (2013) a base enorme de usuários das redes sociais, as tornam mídias favoráveis para anúncios de diferentes empresas. Outros fatores que contribuíram para mais marcas aderirem as mídias sociais foram a sua natureza viral, a presença de concorrentes e o baixo custo das soluções (Tsimonis \& Dimitriadis, 2014).

Bracket and Carr (2001) relatam que informação, entretenimento, irritação e credibilidade impactam de forma significativa o valor do anúncio o que por sua vez, afeta a atitude em relação ao anúncio. Celebi (2015) também demonstra em sua pesquisa que propagandas na internet com conteúdo informativos e de 
entretenimento afetam de maneira positiva a atitude do usuário em relação a propaganda.

No estudo de Bruhn et al. (2012), os autores demonstram que as comunicações tradicionais de massa e as comunicações nas mídias sociais tem impacto na formação do brand equity das marcas, porém de maneira distintas. Enquanto a mídia tradicional impacta o reconhecimento da marca, as mídias sociais influenciam fortemente a imagem das marcas. "As comunicações nas mídias sociais criadas pelas empresas têm importante impacto nos aspectos funcionais da imagem da marca enquanto que as comunicações criadas pelo usuário exercem uma maior influência nos aspectos hedônicos da imagem da marca".

Para as marcas, a utilidade de qualquer site de mídia social decorre do engajamento positivo dos usuários, tornando o conteúdo da marca popular (Berger \& Milkman, 2012). Porém, uma consequência das redes sociais é que elas parecem ter deslocado o foco de comunicação de proprietários de marcas, governos e grandes empresas de mídia em favor de suas audiências (Croft, 2013; Kozinets, 2002) o que favorece o boca-a-boca pois desde que as mídias sociais ofereceram uma oportunidade para os consumidores falarem com centenas ou milhares de outros consumidores ao redor do mundo, empresas não tem mais total controle sobre as suas marcas e não são mais as únicas fontes de comunicação da marca (Bernoff \& Li, 2008; Bruhn et al., 2012). As mídias sociais mais do que nunca "diminuíram as barreiras para compartilhar informação" (Gao \& Feng, 2016).

Comunicações boca-a-boca podem ser definidas como comunicações informais entre indivíduos onde opiniões, reações, visualizações são compartilhadas sobre as características de uma empresa ou sobre a posse, uso ou características de produtos ou serviços da empresa. (Subramani \& Rajagopalan, 2003; Westbrook, 1987). As comunicações boca-a-boca no meio online também é nomeada de boca-a-boca eletrônica. Para Hennig-Thurau, Gwinner, Walsh, e Gremler (2004) definem Boca-a-boca eletrônico como "Qualquer declaração positiva ou negativa feita por clientes potenciais, reais ou anteriores sobre um produto ou empresa, que está disponível para uma infinidade de pessoas e instituições através da Internet". Nesse estudo o boca-a-boca eletrônico será referenciado apenas como boca-a-boca. 
Pesquisas anteriores mostram que a comunicação boca-a-boca é mais influente do que a comunicação feita pela empresa que busca a promoção de sua marca, produto ou serviço (Gilly, Graham, Wolfinbarger, \& Yale, 1998). Isto porque o boca-a-boca é visto como algo mais crível do que as propagandas porque é percebida como uma mensagem enviada por "pessoas iguais a mim" sem o viés das comunicações das empresas (Allsop, Bassett, \& Hoskins, 2007). Porém, no estudo de Nisar e Whitehead (2016), os autores identificaram que indivíduos acreditam mais em informações vindas dos perfis oficiais das marcas nas mídias sociais do que as vindas de um amigo nas mídias sociais.

E de acordo com Barreto (2013), a recomendação feita por um amigo adiciona um componente social, transferindo a credibilidade de um amigo para a propaganda. Além disso, a propaganda poderia se beneficiar da pressão social exercida pelo grupo social do indivíduo nas redes sociais, influenciando o indivíduo a mudar sua atitude, o que poderia levar a mudança também no comportamento. Por outro lado, as marcas estão sujeitas a comentários negativos e prejudiciais dos usuários (Bernoff \& Li, 2008) mas isso não deve ser uma preocupação das marcas pois, de acordo com Ralphs (2011), a quantidade de comentários negativos feitos em cima de posts publicados pelas marcas é muito pequena. No estudo de Bonsón, Carvajal-Trujillo, e Escobar-Rodriguez (2015) a maior parte dos comentários feitas nos posts pelos usuários foi positiva.

De acordo com Berger (2014), o boca-a-boca é mais eficiente que a publicidade tradicional por dois motivos-chave: i) é mais persuasivo, pois normalmente é feito por amigos; e ii) é mais direcionado, pois é naturalmente dirigido para um público interessado. Em geral, não se compartilha uma notícia ou uma recomendação com todo mundo que se conhece. Em vez disso, os usuários têm a tendência de selecionar pessoas específicas que possam considerar aquela informação mais relevante (Berger, 2014). E uma informação muito relevante do estudo de Bughin, Doogan, e Vetvik (2010), o boca-a-boca é o fator primário por trás de $20 \%$ a $50 \%$ de todas as decisões de compra. 


\subsection{Bancos nas mídias sociais}

A adoção e utilização de mídia social pelos bancos vem aumentando internacionalmente (Murray, Durkin, Worthington, \& Clark, 2014) e se tornam uma parte mais permanente de suas estratégias de marketing (Karaduman, 2013). No entanto, a utilização eficaz das mídias sociais de uma maneira orientada para o cliente parece menos evidente (Murray et al., 2014). Para Bolton et al. (2013), as instituições financeiras precisam desenvolver formas de usar as mídias sociais que criem valor social para (e com) o consumidor de acordo com os princípios de co-criação de valor. Porém, Mitic e Kapoulas (2012), ressaltam que as instituições financeiras só deveriam usar plataformas de redes sociais se atender às demandas dos consumidores. Porém, Weinberg, de Ruyter, Dellarocas, Buck, e Keeling, (2013) afirmam que as instituições financeiras implementam aplicações de mídias sociais sem um profundo conhecimento orientado para o consumidor. O que torna necessário entender o valor que os consumidores recebem.

De acordo com o estudo realizado por (Dotson, Beatson, \& Drennan, 2016) os resultados sugerem que os consumidores usarão as mídias sociais se as instituições financeiras criarem e articularem claramente $o$ valor para 0 consumidor ao usar as mídias sociais. O setor também precisa abordar as percepções de segurança da tecnologia para aumentar o uso das mídias sociais (Dootson et al., 2016).

Em termos econômicos, as mídias sociais, em comparação com outros canais de comunicação alternativos, oferecem às instituições financeira um modo mais eficiente para ouvir e desenvolver uma compreensão maior dos seus consumidores (Berry et al., 2010; Laroche et al., 2012).

Pesquisas foram feitas para entender como as mídias sociais podem ser usadas por instituições financeiras para melhorar a reputação corporativa (Bonson \& Flores, 2011; Bravo \& Pina, 2012; Rokka, Karlsson, \& Tienari, 2014), como ferramenta para o marketing de relacionamento ( Mitic \& Kapoulas, 2012; Murray et al., 2014), para gestão de marca (Farshid et al., 2011), para fornecer visões atuais do mercado (Chikandiwa, Contogiannis, \& Jembere, 2013) e para agregar valor aos pequenos bancos (Durkin, McGowan, \& Murray, 2014 ). Porém, para 
Murray et al (2014), os estudos sobre o marketing de serviços financeiros ainda não deram a devida atenção as mídias sociais no contexto bancário.

No Brasil, os bancos são percebidos negativamente por uma parcela significativa da população (Nepomuceno \& Porto, 2010), com o entendimento popular de que os bancos recebem ganham muito dinheiro e retornam pouco à sociedade. Esse entendimento é reforçado pelas condições de financiamento no Brasil onde as taxas de juros anuais estão entre as mais altas do mundo. Consequentemente, as marcas de bancos tendem a ser avaliadas desfavoravelmente (Nepomuceno \& Porto, 2010). Não só no Brasil, mas também em outras partes do mundo. Como observado por Farshid et al. (2011), vários são os blogs com conteúdo gerados por consumidores insatisfeitos com bancos. Assim sendo, as mídias sociais podem afetar a reputação da marca (Farshid et al.,2011).

Torna-se vital para os bancos compreenderem como atuar nas mídias sociais, qual a estratégia de comunicação é a mais adequada a seus consumidores, que tipo de conteúdo pode atrair a atenção dos consumidores e gerar um efeito de boca-a-boca positivo, que ajude a construir associações positivas para a marca, qual o momento certo para comunicar, entender qual a frequência para criar um relacionamento. Sobre esse tema, comunicação, ele será visto a seguir em mais detalhes.

\subsection{Comunicação}

A comunicação de uma maneira ampla pode ser entendida como um processo compreendido por nove elementos. As partes principais envolvidas na comunicação são denominadas emissor e receptor. A mensagem e o meio representam as principais ferramentas da comunicação. Codificação, decodificação, resposta e feedback representam as principais funções da comunicação. Por fim, o ruído é o elemento que representa mensagens aleatórias e concorrentes que podem interferir na comunicação pretendida (Belch \& Belch, 2014; Kotler \& Keller, 2006; Shannon, 1948).

Abaixo a descrição de cada um dos elementos de acordo com Kotler e Armstrong (1993) 
- Emissor: a parte que emite a mensagem para outra parte.

- Codificação: processo de transformar o pensamento em forma simbólica.

- Mensagem: o conjunto de símbolos que o emissor transmite. Pode ser verbal ou não verbal, oral ou escrita, ou simbólica.

- Meio: os canais de comunicação através dos quais a mensagem passa do emissor para o receptor. Podem ser pessoais ou impessoais.

- Decodificação: o processo pelo qual o receptor confere significado aos símbolos transmitidos pelo emissor.

- Receptor: a parte que recebe a mensagem emitida pela outra parte

- Resposta: o conjunto de reações do receptor após ter sido exposto à mensagem.

- Feedback: a parte da resposta do receptor que retorna ao emissor.

- Ruído: distorção não-planejada durante o processo de comunicação, que resulta na obtenção de uma mensagem que chega ao receptor diferente do que foi emitida pelo emissor.

A figura 1 abaixo representa o processo de comunicação com os seus nove elementos.

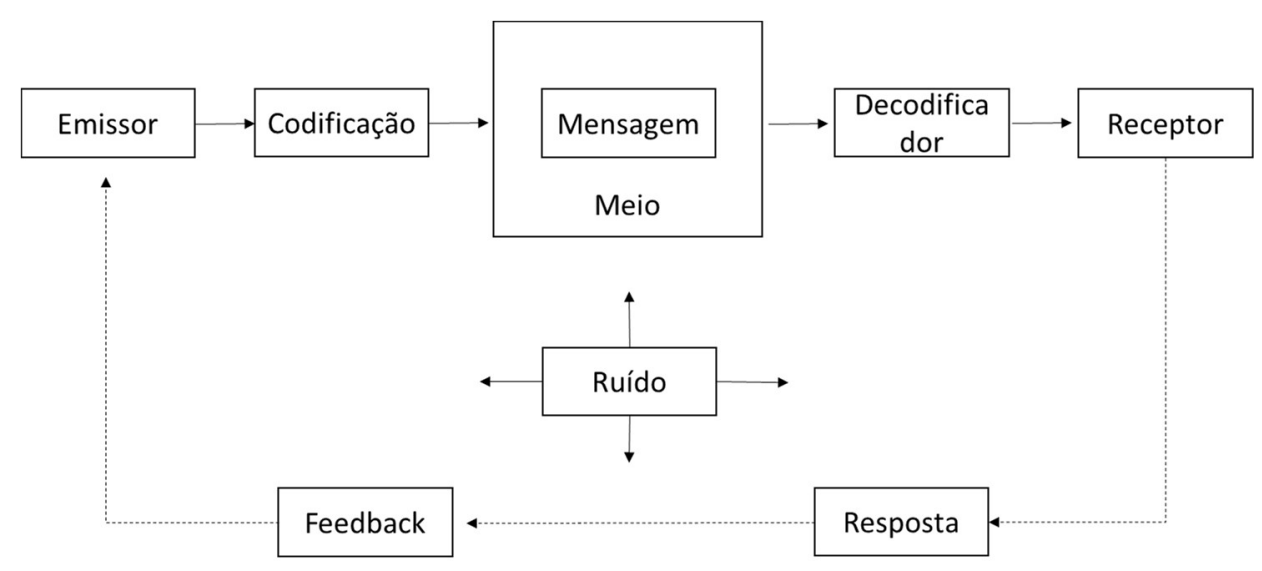

Figura 1- Elementos do processo de comunicação. Kotler e Keller (2006)

2.8 Comunicação das mídias tradicionais para as mídias sociais

Katz e Lazarsfeld em 1955 citado por (Wang \& Nadda, 2015) apresentaram um modelo de comunicação tradicional amplamente aplicado para compreender os 
mecanismos essenciais dentro do processo de comunicação, mas, com limitações devido à natureza de sua comunicação unidirecional. Uma consequência dessa comunicação unidirecional é a limitação de feedback dos públicos-alvo em relação a mensagem enviada (Wang \& Nadda, 2015). Com o surgimento do computador, surge a tecnologia multimídia que reúne os recursos simbólicos e de processamento de várias mídias, criando um rico sistema de comunicação de símbolos (Lim, O'Connor, \& Remus, 2005). Posteriormente, com mais desenvolvimentos tecnológicos aumentou-se as opções de novas mídias que possibilitaram uma maior interação entre empresas e pessoas (Wang \& Nadda, 2015). Com o surgimento das mídias sociais uma das principais vantagens oferecidas por elas para a comunicação está em termos de interatividade e vivacidade que são duas das mais importantes dimensões presentes nas tecnologias de comunicação (Steuer, 1992). A seguir a teoria de usos e gratificações, muito utilizada para explicar as necessidades e motivações de indivíduos com as comunicações nas mídias sociais e os conceitos de interatividade e vivacidade. Por fim, a questão do momento e a frequência para se fazer a comunicação.

\subsection{Usos e Gratificações}

O interesse despertado pelas gratificações que os meios de comunicação de massa ofereciam a seu público remontam a década de 1940 (Katz, Blumler, \& Gurevitch, 1973). Mais recentemente a teoria de usos e gratificações (U \& G) passou a ser mais frequentemente aplicada por pesquisadores de tecnologia e mídia para entender as necessidades e motivações de indivíduos no ambiente online para se engajar com diversas formas de conteúdo (Celebi, 2015; Cvijikj e Michahelles, 2013). De acordo com Sabate et al. (2014), o conteúdo "é o instrumento que estimula a interação. As marcas devem publicar conteúdo tentando abordar as motivações dos clientes, fornecendo conteúdo interessante para elas quando e onde necessário". Para Celebi (2015), gratificação refere-se as necessidades atendidas através do uso da mídia. Se na mídia de massa tradicional a audiência já tinha um papel ativo nas mídias sociais a participação 
é ainda maior onde os usuários podem não só consumir, mas também criar ou contribuir com conteúdo online relacionado a marca (Muntinga, Moorman, \& Smit, 2011).

Vários estudos demonstraram com base na teoria dos usos e da gratificação, que os usuários aplicam as mídias sociais em sua vida diária para interação social, formação / projeção de identidade (Gao \& Feng, 2016; Luarn et al., 2015; Muntinga et al., 2011; Park, Kee, \& Valenzuela, 2009), aquisição de informações, entretenimento (Cvijikj e Michahelles, 2013; De Vries et al., 2012; Gao \& Feng, 2016; Muntinga et al., 2011; Park et al., 2009) e recompensa econômica / incentivo (Cvijikj e Michahelles, 2013; Luarn et al., 2015; Muntinga et al., 2011). $\mathrm{Na}$ literatura, as dimensões mais importantes e robustas da teoria de $U$ \& G incluem entretenimento e informação (Luo, 2002; Muntinga et al., 2011).

O construto de entretenimento pode ser entendido como a medida em que a mídia é divertida e engraçada (Luo, 2002). Podem ser anedotas, vídeos engraçados, teaser, slogan, jogo de palavras (Cvijikj e Michahelles, 2013; Luarn et al., 2015). Pesquisas anteriores sugerem que proporcionar maior valor de entretenimento é susceptível de levar a uma vantagem para os usuários de mídia e motivá-los a usar a mídia com mais frequência (Luo, 2002). Estudo de Cvijikj e Michahelles (2013) encontrou um engajamento maior dos usuários para posts de entretenimento. No intuito de gerar a atenção dos fãs, as marcas podem colocar conteúdos de entretenimento que não estão relacionadas com a marca ou companhia, como vídeos engraçados e anedotas para atrair atenção dos fãs (Luarn et al., 2015).

Diferente de entretenimento, o informacional pode ser definido como a medida em que a web oferece informação útil (Luo, 2002) relacionadas a produto, marca ou sobre a companhia (Cvijikj e Michahelles, 2013; Muntinga et al., 2011; Luarn et al., 2015). O conteúdo informativo dos posts informa os usuários a respeito de alternativas de produtos, capacitando-os a tomar melhores escolhas (Muntinga et al., 2011). Se o post de uma marca contém informações de produtos ou das marcas, fãs são motivados a interagir e consumir (De Vries et al., 2012).

Remuneração pode ser entendida como informações que estão diretamente ou indiretamente relacionados com benefícios como promoções, descontos, 
cupons, concursos, prêmios etc com intuito de atrair a atenção (Cvijikj e Michahelles, 2013, Luarn et al., 2015) e benefícios relacionados a emprego (Nov, 2007). Na pesquisa de Ashley e Tuten (2015), os autores descobriram que as grandes marcas estão investindo mais em concursos que em descontos.

\subsection{Interatividade}

O desenvolvimento tecnológico em comunicação e informação permitiu que as redes sociais impactassem diversos aspectos das vidas das pessoas e das empresas, acelerando a troca de informações e o desenvolvimento de relacionamentos, aumentado nesse processo de comunicação a interatividade (Liu \& Shrum, 2002; Wang \& Nadda, 2015). De acordo com Jiang, Chan, Tan, e Chua (2010), a interatividade tem sido estudada como uma "característica essencial das plataformas de redes sociais em que as atitudes e comportamentos dos visitantes podem ser seduzidos e conduzidos".

A interatividade é reconhecida como um fator essencial na determinação de resultados comportamentais e afetivos como satisfação, atitude, processo de decisão e envolvimento (Coyle \& Thorson, 2001; Fortin \& Dholakia, 2005; Sundar \& Kim, 2005; Stewart \& Pavlou, 2002). E um alto nível de interatividade pode gerar resultados favoráveis de comunicação (Macias, 2003; Sicilia, Ruiz, \& Munuera, 2005).

A interatividade foi estudada nas décadas de 1980 a 1990 do ponto de vista de processo e funcional. A partir de 2000 é vista mais sob a ótica da percepção. Ela tem sido amplamente discutida em áreas como propaganda, marketing, comunicação, ciência da informação, informática e educação" (McMillan \& Hwang, 2002). O conceito de interatividade recebeu atenção acadêmica em diferentes disciplinas como por exemplo, Comunicação mediada por computador (CMC), Comércio Eletrônico (CE), Tecnologia da Informação (TI) e Educação baseada na Web (Wang \& Nadda, 2015). Apesar desse nível de atenção despertado pela interatividade em diversas disciplinas do meio acadêmico, o conceito permaneceu sem um consenso quanto a sua definição. Diversas inconsistências entre as definições e as operacionalizações foram achadas em estudos prévios (Liu \& Shrum, 2002; McMillan \& Hwang, 2002; Wang \& Nadda, 
2015; Wu, 2005). Por exemplo, para Fortin e Dholakia (2005), diferentes tipos de mídias podem exibir diferentes níveis de interatividade e, portanto, o constructo não pode ser categorizado como dicotômico. Algumas definições de interatividade a seguir.

Rafaeli (1988) define a interatividade como "uma expressão na medida que, em uma dada série de trocas de comunicação, qualquer terceira (ou posterior) transmissão (ou mensagem) está relacionada com o grau em que trocas anteriores se referiam a transmissões mais antigas" (p.111).

De acordo com Steuer (1992), interatividade "refere-se ao grau em que usuários de um meio podem influenciar a forma ou o conteúdo do ambiente mediado" (p.84).

Interatividade pode ser definida como "a medida na qual duas ou mais partes em uma comunicação podem atuar uma sobre a outra, no meio de comunicação e nas mensagens e, na medida na qual tais ações são sincronizadas" (Liu \& Shrum, 2002, p.54).

"A interatividade é o estado ou o processo de comunicação, intercâmbio, obtenção e / ou modificação de conteúdo (por exemplo, idéias, entretenimento, informações do produto) e / ou sua forma com ou através de um meio (por exemplo, computador, modem, etc.) que responde tanto às necessidades de comunicação do comunicador quanto a do público, através da inclusão de links de hipertexto, comunicação recíproca, etc" (Macias, 2003).

Para Fortin e Dholakia (2005), interatividade pode ser definida como:

O grau em que um sistema de comunicação pode permitir que um ou mais usuários finais se comuniquem alternativamente como remetentes e receptores com um ou vários outros usuários ou dispositivos de comunicação, seja em tempo real (como em uma teleconferência de vídeo) ou em um modo de armazenamento e envio (como em um correio eletrônico), ou procurar e obter acesso a informações sob demanda, onde o conteúdo, o tempo e a seqüência da comunicação estão sob controle do usuário final, em oposição ao modo tradicional de transmissão (p.388).

Para Schumann, Andy e Rachel (2001), interatividade "é a escolha do consumidor interagir, portanto, a interatividade é uma característica do consumidor e não uma característica do meio". 
A partir do estudo de diversos autores sobre interatividade (Liu \& Shrum, 2002), chegou-se à conclusão que a interatividade pode ser descrita através de 3 características: controle ativo, comunicação bidirecional e sincronicidade. O controle ativo é caracterizado por "ação voluntária e instrumental que influencia diretamente a experiência do controlador". A comunicação bidirecional refere-se à "capacidade de comunicação recíproca entre empresas e usuários e usuários e usuários". Por fim, a sincronicidade refere-se ao "grau em que a entrada dos usuários em uma comunicação e a resposta que recebem da comunicação são simultâneas".

McMillan e Hwang (2002), chegaram a uma conclusão parecida com algumas diferenças. Elas revisaram 30 artigos e concluíram que três elementos aparecem freqüentemente na literatura de interatividade: direção de comunicação, controle de usuário e tempo. A direção da comunicação diz respeito a capacidade de resposta e a troca, o controle do usuário inclui funções como participação e recursos como motores de busca e o conceito de tempo engloba questões como o feedback oportuno e o tempo necessário para a recuperação da informação.

McMillan e Hwang (2002) e Liu e Shrum (2002) trazem à tona, além das características levantadas anteriormente descritas, a importância das percepções dos participantes em contextos de comunicação interativa. Liu e Shrum (2002), sugerem que a influência da interatividade na eficácia da propaganda pode ser em função das características da pessoa e da situação. Para Wang \& Nadda (2015) a percepção da interatividade está mais intimamente relacionada aos usuários, do que em relação a comunicação e mídia. Dessa forma, torna-se importante saber quais características pessoais dos consumidores fazem com que eles percebam de forma diferente o mesmo meio e a mensagem de forma diferente. Conforme colocado por Wu (2005) a visão perceptiva indica que o maior potencial da interatividade reside mais na percepção dos usuários em relação as interações do que na interatividade real através de tecnologias. 


\subsection{Vivacidade}

O conceito de vivacidade assim como o de interatividade também não tem um consenso quanto a sua definição e também quanto a sua operacionalização (Taylor \& Thompson,1982). A seguir algumas definições de vivacidade.

Vivacidade se refere ao grau em que um ambiente mediado pode simular uma experiência sensorial direta (Coyle \& Thorson, 2001).

A vivacidade, refere-se à capacidade de uma tecnologia para produzir um ambiente mediado sensorialmente rico (Steuer, 1992).

Vivacidade é "a medida na qual um post de marca estimula diversos sentidos" (Luarn et al., 2015).

Nisbett e Ross (1980, p.45) descreveram informação vívida como capaz de "atrair e manter nossa atenção e excitar a imaginação na medida em que seja (a) emocionalmente interessante; $(B)$ de provocação concreta e imagética; e (c) próximo de uma maneira sensorial, temporal ou espacial".

Quanto as dimensões de vivacidade, de acordo com Steuer (1992), esta possui a amplitude e profundidade da mensagem: sendo a amplitude o número de dimensões sensoriais simultaneamente apresentados (cores, gráficos, etc.), e a profundidade à qualidade da informação sensorial disponível a qual dependerá da largura da banda de dados do canal de transmissão.

Vídeo e imagens são ferramentas comuns utilizadas para enriquecer a vivacidade (Coyle \& Thorson, 2001; Taylor \& Thompson, 1982; Xu, Oh, \& Teo, 2009). Textos com fotos são mais vividos do que apenas textos (Van Der Heide, D’Angelo, \& Schumaker, 2012; Wang, Moon, Kwon, Evans, \& Stefanone, 2010). Para Tafesse (2015), vivacidade é uma característica tanto do meio quanto do conteúdo. Dentro do mesmo meio, conteúdo pode ser utilizado de diferentes maneiras para obter diferentes níveis de vivacidade.

Como apontado no início desse capítulo, a vivacidade não tem um consenso quanto a sua definição e nem quanto a sua operacionalização. Por isso, nota-se estudos prévios com divergências em relação aos resultados da vivacidade. Em alguns estudos chegou-se à conclusão que mensagens vívidas podiam 
aumentar o processamento da mensagem e a persuasão. Em outros podiam inibir ou não ter nenhum efeito (Taylor \& Thompson, 1982; Frey \& Eagly, 1993; Smith \& Shaffer, 2000). Além disso, segundo Taylor e Thompson (1982), a vivacidade depende não apenas das características do estímulo das mensagens, mas também das características dos receptores.

Portanto, percebe-se que vivacidade e interatividade são dois conceitos amplamente empregados e importantes nas mídias sociais, mas que ainda carecem da validação de um construto e também da sua operacionalização, o que acaba por trazer resultados divergentes em muitos estudos.

Por fim, a questão do momento para veiculação da mensagem.

\subsection{Dimensão tempo}

A dimensão de tempo, do momento para publicação das mensagens parece ser fator importante nas mídias sociais e especificamente para as marcas no Facebook. De acordo com Boland (2014), "as pessoas só têm um período determinado de tempo para ler essas histórias e geralmente deixam passar as que não estão no topo". Ainda segundo o autor, os posts que não estão no topo têm menos chances de serem lidos. Dessa forma, o horário que vai ser veiculado a mensagem é essencial para que a mensagem tenha chance de ser vista. Da mesma maneira influenciam na chance de ser visto, o dia da semana. Idealmente, elas devem ser publicadas no horário que a pessoa costuma acessar as mensagens. Essas variáveis são utilizadas para avaliar o impacto da mensagem nos usuários por diversos autores (Cvijikj \& Michahelles, 2013; Chauhan \& Pillai, 2013; de Vries et al., 2012; Sabate et al., 2014). 


\section{MÉTODO}

A escolha do método de pesquisa está vinculada ao objetivo do estudo, a questão de pesquisa que se quer responder. Somente após definido a questão de pesquisa, etapa crucial no processo de pesquisa, é possível conduzir o tipo de pesquisa (Cooper \& Schindler, 2014). Uma vez que o objetivo da pesquisa é compreender a estratégia de comunicação dos bancos nas redes sociais, mais especificamente no Facebook, foram analisados os tipos de pesquisas existentes para a definição do melhor método que suportasse este estudo e o método mais apropriado é o da pesquisa qualitativa.

\subsection{Pesquisa qualitativa}

Segundo Belk, Fischer, \& Kozinets (2013 as pesquisas qualitativas têm as seguintes características:

- Natureza dos dados. Registros verbais e visuais são ricos em detalhes.

- Relevância do contexto. Resultados geralmente são específicos em relação ao tempo, lugar, pessoas e, cultura estudada.

- Natureza e controle das causas potenciais. Idealmente naturalista com fatores múltiplos moldando os comportamentos observados e discutidos.

- Instrumentos chave de pesquisa. O pesquisador é o principal instrumento e usa as suas habilidades e relacionamento para ganhar insights baseados na sua confiança.

\subsection{Definições importantes no planejamento da pesquisa}

Cooper e Schindler (2014) levantam algumas questões importantes no planejamento de uma pesquisa quanto a manipulação das variáveis, a dimensão do tempo, o ambiente em que a pesquisa é realizada.

Em relação a manipulação das variáveis, classificam os projetos em experimentais ou ex post facto. Em um experimento o pesquisador controla e/ou manipula as variáveis. Já em um projeto ex post facto o pesquisador não tem 
nenhum controle ou poder de manipulá-las. Apenas pode observar o que aconteceu ou está acontecendo.

Quanto a dimensão do tempo, as pesquisas são transversais ou longitudinais. Nas transversais a coleta das informações se dá uma única vez. Já nas longitudinais, as coletas são feitas mais de uma vez em dado um período de tempo.

Por último, o ambiente em que a pesquisa ocorre, esta pode ser em condições de campo (ambiente reais) ou condições de laboratório. No laboratório as variáveis podem ser melhor controladas, porém perdem em naturalidade, em realidade, como em condições de campo.

Portanto, este estudo será feito em uma pesquisa qualitativa, ex post facto, transversal e em condições de campo.

\subsection{Método de coleta de dados}

De acordo com Cooper e Schindler (2014) a forma de coleta de dados pode ser feita por dois tipos de processo: monitoramento ou comunicação. No processo de monitoramento, o pesquisador inspeciona a atividade do sujeito ou a natureza de algum material sem tentar obter a resposta de qualquer pessoa. Já no processo de comunicação o pesquisador pergunta os sujeitos e coleta as suas respostas seja por meios pessoais ou impessoais. Neste estudo a coleta se dará pelo processo de monitoramento onde os posts publicados pelas marcas serão coletados diariamente nas suas páginas no Facebook. A coleta diária é importante pois algumas marcas colocam algumas comunicações, mas por algum motivo depois de um período retiram da sua página. Como o objetivo desse estudo é analisar as estratégias de comunicação, deixar de captar essas comunicações pode ser relevante. Abaixo na figura 2, exemplo de um post coletado da página do Citibank. O post ocupa sempre a região central da página. Essa região onde ficam os posts é conhecida como newsfeed - é um mural de notícias. Tem sempre esse formato com as seguintes características. No canto superior esquerdo aparecem a marca e a data do post. Logo abaixo a área destinada ao texto do post onde podem ser inseridos hyperlinks, hashtags, 
emoticons. Abaixo da área de texto são colocadas as imagens que podem ser foto, álbum, vídeos sem som - podem ser em formato GIF ou MP4, por exemplo, e vídeo com som. Por último, fica a área de engajamento onde se encontram os botões de curtir, compartilhar ou comentar e seus resultados.

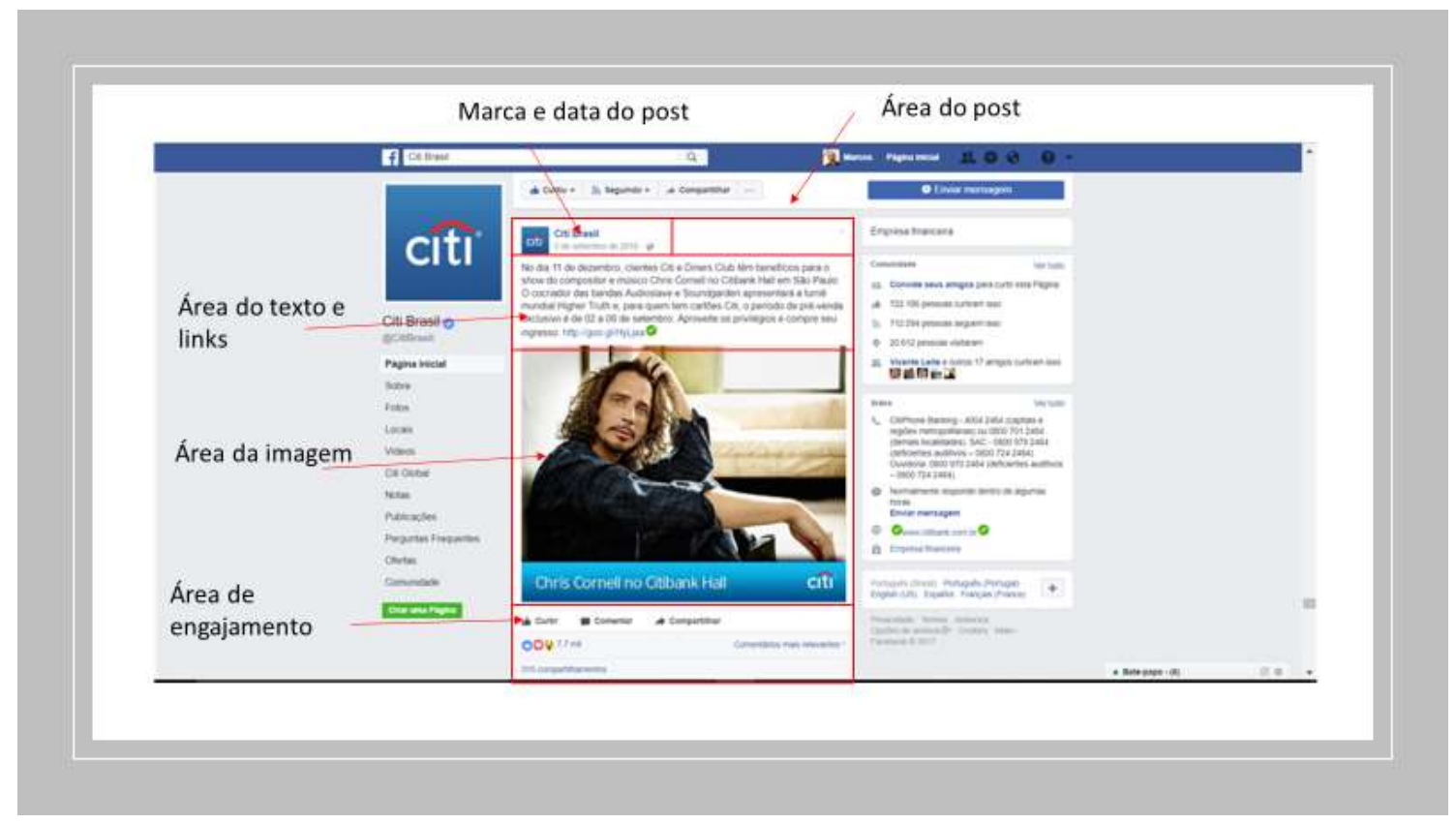

Figura 2 - Exemplo de um post

\subsection{Tamanho da amostra}

Sayre (1992) sugere que uma amostra gerenciável e representativa do meio utilizado por uma determinada audiência varia entre 50 a 200 propagandas. Press (2011) coletou em seu estudo 287 mensagens de três marcas diferentes no Facebook em 91 dias. Costa, De Almeida, Limongi, e Scalco (2013) coletaram durante três meses 2.584 observações referentes a oito marcas de cerveja. Luarn et al. (2015) coletaram 1.030 posts de dez marcas durante dois meses. Tafesse (2015) coletou durante seis semanas 191 posts de 5 marcas do ramo automotivo.

Para este estudo foram coletados diariamente 906 posts durante 6 meses de 2016 (julho a dezembro) de seis marcas de bancos. 
3.5 Seleção das marcas a serem pesquisadas

Foi escolhido um setor da economia brasileira que fosse bastante representativo e pouco estudado no âmbito das mídias sociais. O setor escolhido foi o de serviços que representa mais de $60 \%$ do PIB da economia brasileira (Pereira, 2015). Dentro do setor de serviços buscou-se definir as marcas através do valor da sua marca, do porte da instituição (Patrimônio Líquido) e as marcas que possuíam página oficial no Facebook. Assim as marcas escolhidas foram os bancos Itaú, Bradesco, Banco do Brasil, Caixa Econômica Federal (CEF), Santander e Citibank.

Para valor de marca foi o utilizado o ranking publicado pela Revista de Banker dos Estados Unidos junto com a consultoria internacional de marcas Brand Finance. Entre as dez marcas de bancos mais valiosas na América Latina, não foram encontradas páginas oficiais no Brasil das marcas BBVA, Goldman Sachs e Deutsche Bank. HSBC possuía página mas deixou de ter a página oficial com a compra do Bradesco das operações de varejo no Brasil. A coleta da página chegou a ser iniciada, mas no dia 02/07/16 a página não foi mais encontrada no Facebook e, dessa forma, o HSBC deixou de ser considerado na amostra.

\begin{tabular}{|l|l|r|}
\hline Posição & Marca & $\begin{array}{r}\text { Valor } 2014 \\
\text { (US\$M) }\end{array}$ \\
\hline 1 & Santander & 10.965 \\
\hline 2 & Bradesco & 10.600 \\
\hline 3 & Itaú & 9.904 \\
\hline 4 & Banco do Brasil & 6.972 \\
\hline 5 & Citi & 5.027 \\
\hline 6 & Caixa & 4.759 \\
\hline 7 & HSBC & 4.105 \\
\hline 8 & BBVA & 2.033 \\
\hline 9 & Goldman Sachs & 1.998 \\
\hline 10 & Deutsche Bank & 1.112 \\
\hline
\end{tabular}

Tabela 1 - As 10 marcas de bancos mais valiosas na América Latina, Fonte: The Banker/ Brand Finance, 2014 
Dos 10 maiores bancos por patrimônio líquido não foram encontradas páginas oficiais no Facebook dos bancos BTG Pactual, Safra e Votorantim. O patrimônio líquido dos bancos Itaú, Bradesco, Banco do Brasil, Caixa Econômica Federal, Santander e Citibank representavam em junho/2014 quase 61\% de todo patrimônio líquido dos bancos em operação no Brasil.

\begin{tabular}{|l|l|r|}
\hline Posição & Marca & Patrimônio Líquido Jun/2014 \\
\hline 1 & Itaú & $\mathrm{R} \$ 93.404 .950,00$ \\
\hline 2 & Bradesco & $\mathrm{R} \$ 76.964 .400,00$ \\
\hline 3 & Banco do Brasil & $\mathrm{R} \$ 70.043 .646,00$ \\
\hline 4 & Santander & $\mathrm{R} \$ 58.961 .469,00$ \\
\hline 5 & Caixa Econômica Federal & $\mathrm{R} \$ 28.244 .519,00$ \\
\hline 6 & BTG Pactual & $\mathrm{R} \$ 13.425 .118,00$ \\
\hline 7 & HSBC & $\mathrm{R} \$ 10.015 .959,00$ \\
\hline 8 & Safra & $\mathrm{R} \$ 8.109 .737,00$ \\
\hline 9 & Votorantim & $\mathrm{R} \$ 7.586 .576,00$ \\
\hline 10 & Citibank & $\mathrm{R} \$ 7.089 .024,00$ \\
\hline
\end{tabular}

Tabela 2 - As 10 marcas de bancos por Patrimônio Líquido no Brasil, Fonte: Bacen, 2014

Por fim, verificamos dentro das páginas oficiais dos bancos a quantidade de fãs de cada uma das páginas.

\begin{tabular}{|l|r|}
\hline \multicolumn{1}{|c|}{ Marca } & Quantidade de fãs \\
\hline Itaú & 8.346 .362 \\
\hline Bradesco & 4.928 .753 \\
\hline Banco do Brasil & 2.267 .295 \\
\hline Caixa Econômica Federal & 1.953 .058 \\
\hline Santander & 1.688 .461 \\
\hline Citibank & 999.812 \\
\hline
\end{tabular}

Tabela 3 - Quantidade de fãs dos bancos no Facebook, Fonte: Facebook, $\mathrm{jul} / 2014$ 
Abaixo as páginas oficiais das marcas selecionadas com um breve descritivo dos bancos.

O Itaú é um banco privado brasileiro com o maior lucro entre os bancos no Brasil. Foi fundado em 1924.

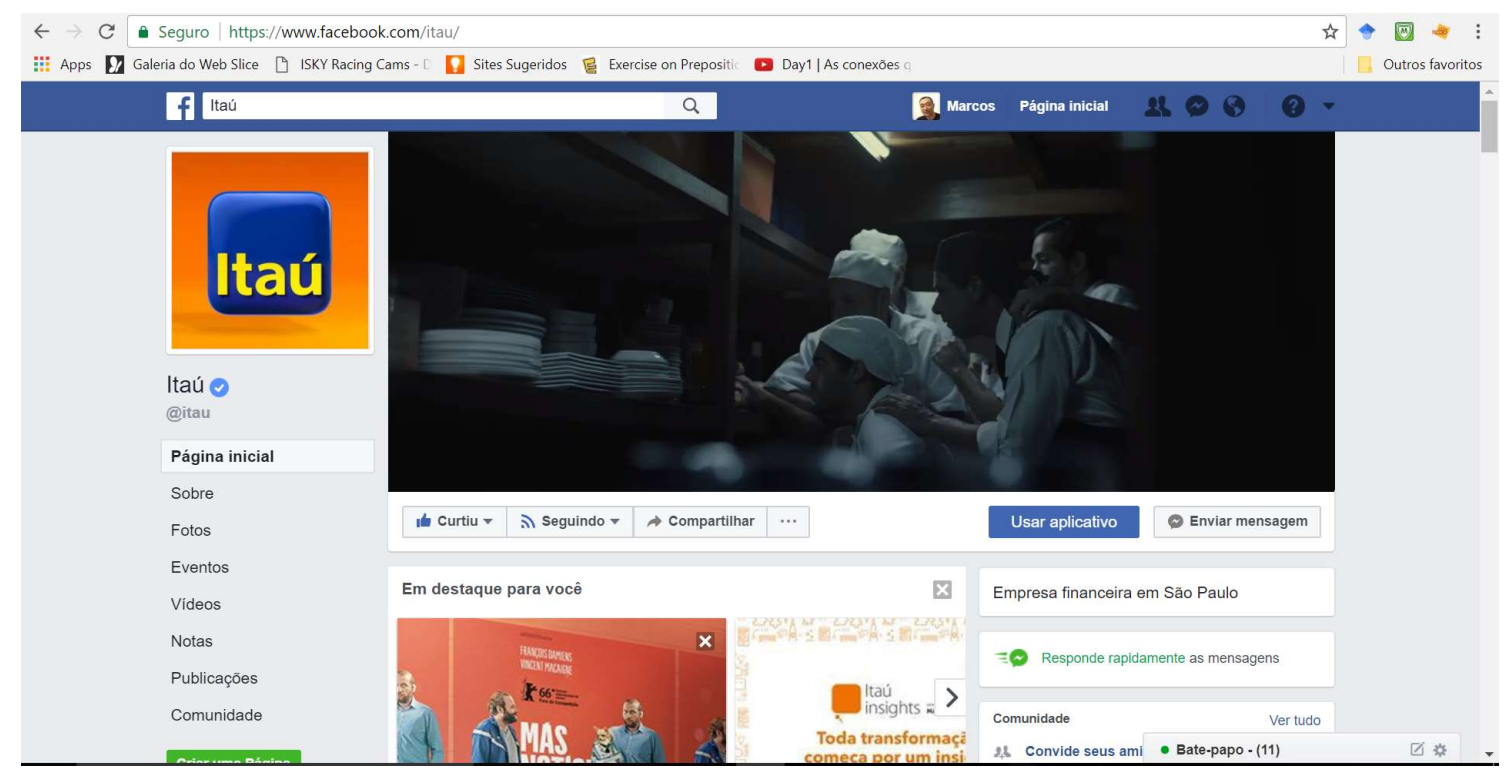

Figura 3 - Página oficial do Itaú

Bradesco é um banco privado brasileiro com o $2^{\circ}$ maior lucro entre os bancos no Brasil. Foi fundado em 1943. 


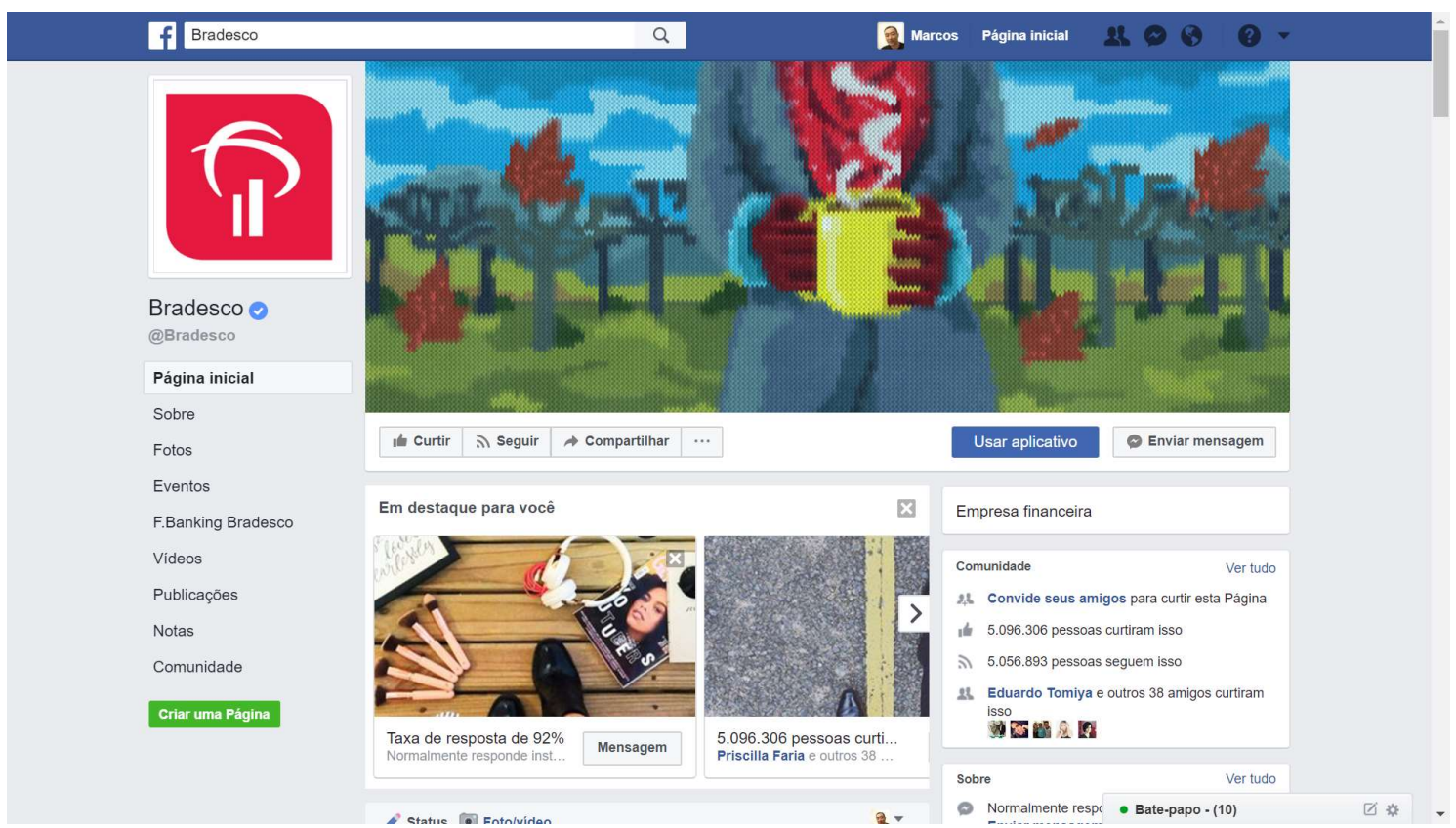

Figura 4 - página oficial do Bradesco

Banco do Brasil é um banco público brasileiro. Foi fundado em 1808. Banco que sempre apoiou o agronegócio. De espírito público, valoriza a cultura e o esporte do nosso país.

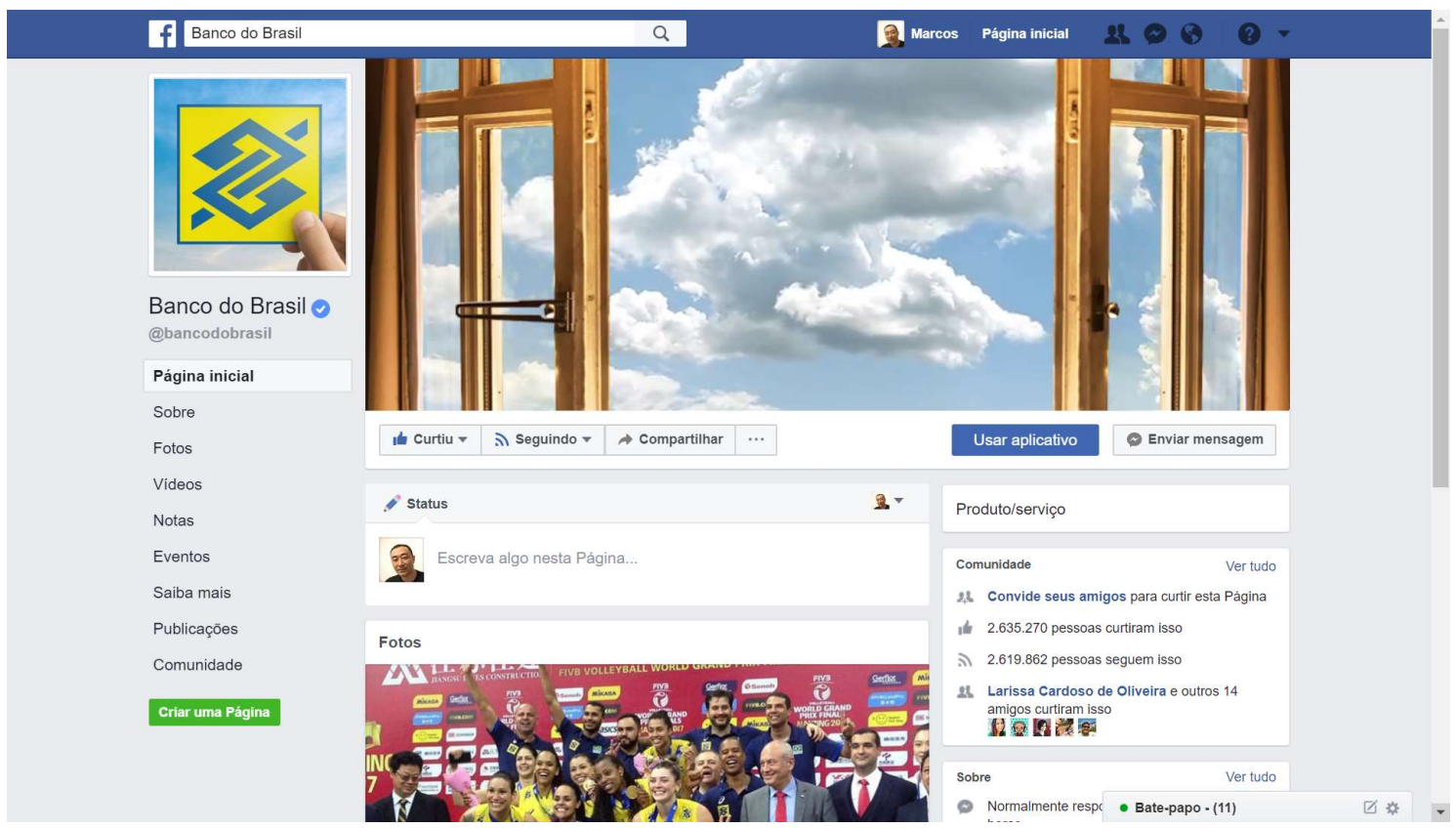

Figura 5 - Página oficial do Banco do Brasil 
CEF é um banco público brasileiro. Foi fundado em 1861. A Caixa Econômica Federal além dos produtos e serviços financeiros tradicionais também oferece produtos e serviços exclusivos como FGTS, Bolsa Família, Minha Casa Minha Vida, Fundo de Garantia, Seguro Desemprego, INSS, PIS, CNPJ, Melhor Crédito, Minha Casa Melhor e loteria. Dados retirados da sua página no Facebook.

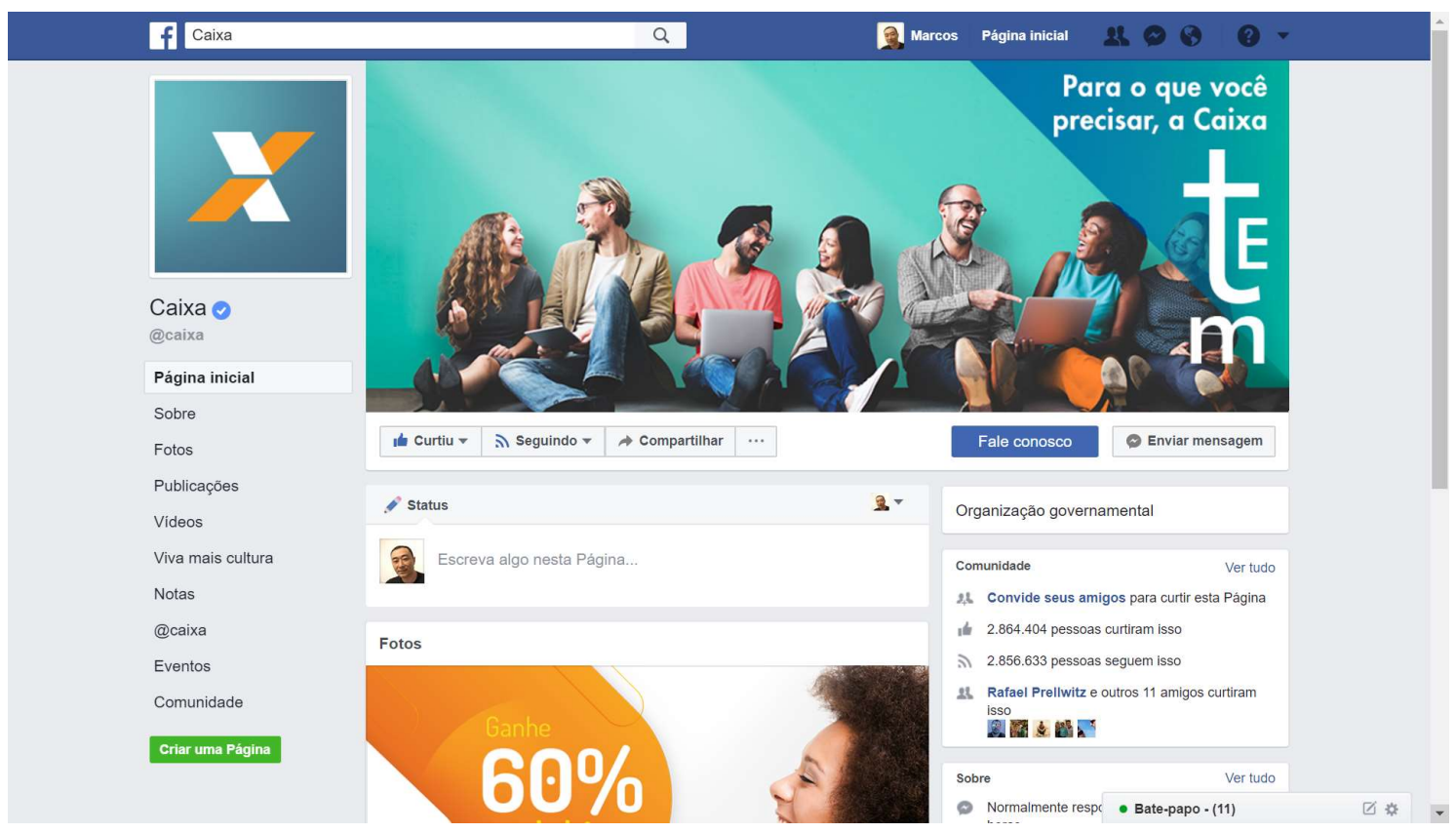

Figura 6 - Página oficial da Caixa Econômica Federal (CEF)

Santander é um banco privado espanhol. Foi fundado em 1857. De acordo com sua página no Facebook, tem como propósito contribuir com o progresso das pessoas e dos negócios no País, por meio da prestação de serviços financeiros, geração de valor e do investimento em iniciativas sociais e culturais. 


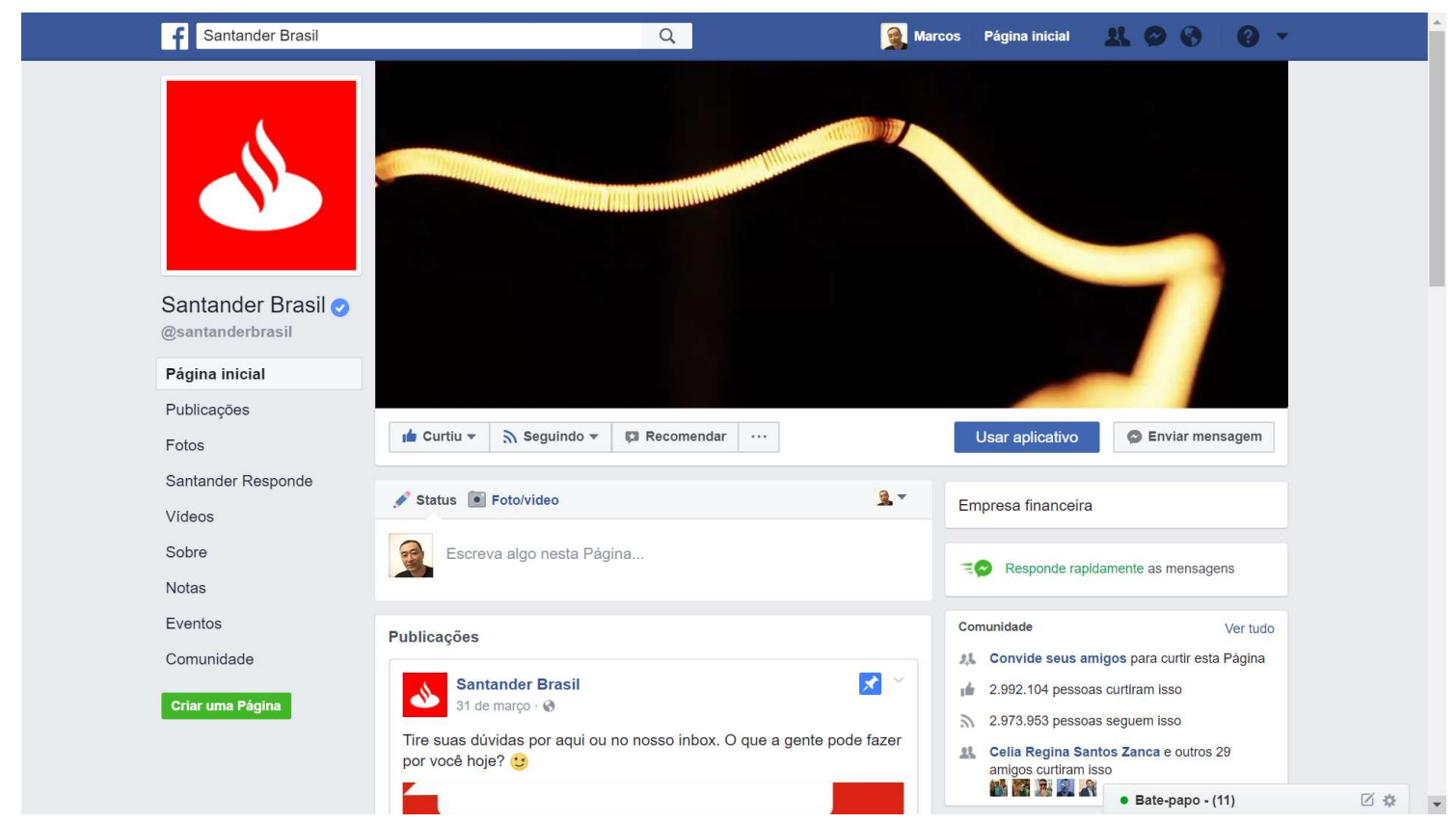

Figura 7 - Página oficial do Santander

Citibank é um banco privado americano. Foi fundado em 1812 e é um banco global. Realiza operações em mais de 160 países. Oferece a pessoas, corporações, governos e instituições uma ampla série de produtos e serviços financeiros, incluindo serviços bancários, seguros, crédito ao consumidor, atendimento corporativo, investimento feito pela Citi Corretora, corretagem de valores e administração patrimonial, segundo dados da sua página no Facebook. 


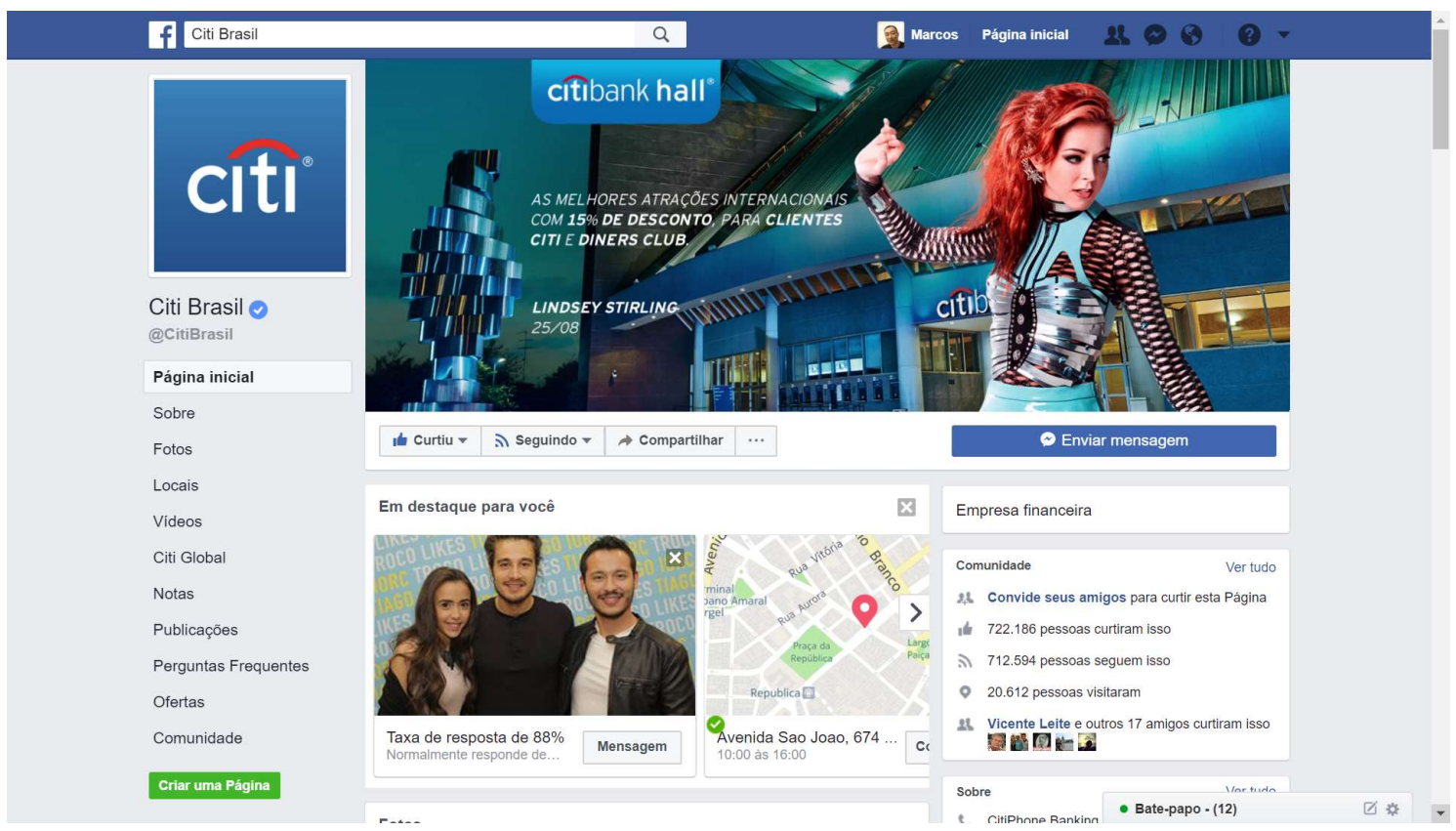

Figura 8 - Página oficial do Citibank

\subsection{Procedimentos de análise}

Neste estudo será feito uma análise de conteúdo dos posts coletados dessas marcas para analisar os diversos elementos presentes na estratégia de comunicação das marcas dos bancos no Facebook no mercado brasileiro. De acordo com Ashley \& Tuten (2015), a análise de conteúdo é útil para identificar as estratégias das marcas nas mídias sociais.

De acordo com Bardin (2009), a análise de conteúdo pode ser descrita como "um conjunto de técnicas de análise das comunicações visando obter por procedimentos sistemáticos e objetivos de descrição do conteúdo das mensagens, indicadores (quantitativos ou não) que permitam a inferência de conhecimentos relativos as condições de produção/recepção (variáveis inferidas) destas mensagens".

Para Hosti (1968) citado por Sayre (1992, p.16), com o propósito de usar análise de conteúdo para pesquisas com o consumidor, é possível defini-la como "um método de análise de mensagens de comunicação utilizando um procedimento sistemático de contagem de itens dentro de categorias estabelecidas".

Krippendorff (2013, p.24) define análise de conteúdo como "uma técnica de pesquisa para fazer inferências válidas e replicáveis dos textos (ou outro 
conteúdo significativo) até o contexto do seu uso". O autor contextualiza que análise de conteúdo vai além da análise de texto e engloba outros elementos tais como trabalhos de arte, imagens, mapas, sons, sinais, símbolos, ou até mesmo dados numéricos.

Buijzen e Valkenburg (2002, p.349) vem a análise de conteúdo de propaganda como uma rica fonte de dados da visão dos anunciantes sobre quais características de uma propaganda atraem os seus públicos-alvo. Além disso, veem a análise de conteúdo como uma ferramenta valiosa para prever e entender a efetividade da propaganda.

Nesse sentido, Budd, Thorp, e Donohew (1967) citado por Sayre (p.16) sugerem que a técnica é ideal para observar e analisar o comportamento de determinados comunicadores.

Krippendorff (2013) considera que o conteúdo irá emergir do processo de interação do pesquisador com o texto. Essa ideia traz consigo a noção de que cada pesquisador irá interpretar determinado texto de acordo com suas próprias características e com o contexto em que o texto está inserido. Porém, Smith (2000) ressalta que ao realizar uma análise de conteúdo é necessário definir explicitamente todos os procedimentos de análise dos dados, pois é somente assim que será possível ter um nível maior de objetividade evitando o viés do pesquisador na busca de uma compreensão dos dados sendo analisados.

Segundo Bardin (2009), a análise de conteúdo, é dividida em três etapas: (1) pré-análise, (2) exploração do material e (3) tratamento dos resultados, inferência e interpretação.

\subsubsection{Pré-análise}

A pré-análise é a etapa que busca sistematizar, organizar as ideias iniciais. Geralmente esta etapa é constituída de 3 missões: (1) a escolha dos documentos a serem submetidos à análise, (2) a formulação das hipóteses e objetivos e (3) a elaboração de indicadores que fundamentem a interpretação final.

De acordo com Smith (2000) os documentos a serem submetidos à análise, podem ser: 
- Material de arquivo: produtos culturais simbólicos, documentos pessoais, publicações, arquivos e documentos oficiais, transcrição de material da mídia.

- Material de ocorrência natural: eventos ao vivo, sessões de psicoterapia, conversações, trocas de e-mails e deliberações de grupos.

- Material coletado: respostas às perguntas feitas numa entrevista ou coletadas por meio de técnicas projetivas.

Os documentos na nossa pesquisa são as páginas das marcas que foram baixadas para o computador utilizando o recurso do navegador Google Chrome de "Salvar como".

\subsubsection{Exploração do material}

A próxima etapa, a exploração do material, consiste em operações de codificação, decomposição ou enumeração, em função de regras previamente formuladas (Bardin, 2009, p.127)

A autora destaca os seguintes procedimentos para a exploração do material:

- escolha das unidades (registro e contexto);

- escolha das regras de contagem;

- escolha das categorias.

Bardin (2009, p. 130) define unidade de registro como sendo "a unidade de significação a codificar e corresponde ao segmento do conteúdo a considerar como unidade de base, visando a categorização e a contagem frequencial". Entre as unidades de registro mais utilizadas (Bardin, 2009, p.130) está o tema que é "a unidade de significação que se liberta naturalmente de um texto analisado segundo certos critérios relativos à teoria que serve de guia à leitura" (Bardin, 2009, p.131). O tema será a unidade de registro a ser utilizado na pesquisa. Justifica-se o uso de tema pois como apontado por Bardin (2009,p.131) " ... as comunicações de massa, etc., podem ser, e são frequentemente, analisados tendo o tema por base". 
Já unidade de contexto, "corresponde ao segmento de mensagens cujas dimensões (superiores às unidades de registro) são ótimas para que se possa compreender a significação exata da unidade de registro" (Bardin, 2009, p.133). A unidade de contexto na pesquisa serão as mensagens postadas pelas marcas nas suas páginas no Facebook.

A regra de contagem diz respeito ao modo de contagem. De acordo com Bardin (2009, p.134-139) são vários os tipos de enumerações: presença (ou ausência), frequência (ponderada ou não), intensidade, direção, ordem e co-ocorrência.

- presença (ou ausência): a presença ou ausência de um elemento pode ser significativo, funcionando como um indicador;

- frequência (ponderada ou não): indica a relevância de uma unidade de registro. $\mathrm{Na}$ frequência simples todas as aparições tem o mesmo peso enquanto na ponderada a aparição de determinado elemento tem mais importância do que outro;

- intensidade: a medição das variações semânticas em uma classe de elementos. Deve-se levar em consideração a intensidade semântica do verbo, tempo verbal, advérbios de modo, adjetivos e atributos qualitativos;

- ordem: a ordem de aparição das unidades de registro;

- co-ocorrência: presença simultânea de duas ou mais unidades de registro numa unidade de contexto.

A partir do momento em que a análise de conteúdo decide codificar o material, deve produzir um sistema de categorias. As categorias são rubricas ou classes, as quais reúnem um grupo de elementos (unidades de registro, no caso da análise do conteúdo) sob um título genérico, agrupamento esse efetuado em razão das características comuns destes elementos. (Bardin, 2009, p.145)

A categorização segundo Bardin (2009, p.145) é "uma operação de classificação de elementos constitutivos de um conjunto por diferenciação e, seguidamente, por reagrupamento segundo o gênero (analogia), com os critérios previamente definidos". O critério de categorização pode ser: semântico (categorias temáticas), sintático (verbos, adjetivos), léxico (segundo o sentido da palavra) e expressivo (segundo as expressões de linguagem). 
O sistema de categorias pode ser resultado de uma teoria que suporta a pesquisa, da análise progressiva dos elementos do texto ou ainda a junção dos dois (Bardin, 2009). Nesse estudo utilizou a teoria de Usos e Gratificações, conceitos de Interatividade e Vivacidade, e estudos que avaliaram as dimensões de data/horário.

Bush, Hair e Bush (1983) sugerem o uso de questionário com instruções para categorizar cada uma das variáveis a serem analisadas afim de organizar o processo de análise. O pesquisador deve definir categorias de análise, criar definições operacionais e proceder com a análise dos dados. Com base nessas considerações construiu-se um guia de codificação para analisar as propagandas coletadas utilizando-se o Excel para suportar o processo de construção da base de dados.

Conforme descrito no início deste estudo, essa pesquisa buscará entender as estratégias de comunicação das marcas no Facebook. Portanto, buscará entender como a mensagem através dos vários elementos que a compõe, são emitidas para o usuário. São estes elementos que estão sujeitos a categorização. Estes elementos são diversos, como por exemplo, o formato (vídeo, texto ou fotos), o conteúdo da mensagem (informacional, entretenimento e remuneração) entre vários outros fatores. A categorização inicial tomou como base o referencial teórico apresentado anteriormente. Categorias levantadas: $O$ quadro 2 mostra as categorias com as subcategorias previstas inicialmente com a descrição de cada variável, o referencial teórico que suportou a criação de cada uma delas e a codificação. 


\begin{tabular}{|c|c|c|}
\hline Categoria & Subcategoria & Descrição \\
\hline \multirow{3}{*}{$\begin{array}{l}\text { Usos e } \\
\text { Gratificações }\end{array}$} & Informativo & Informação útil ligada a produto, a marca , ou a empresa \\
\hline & Entretenimento & $\begin{array}{l}\text { conteúdo engraçado, divertido, lúdico, passatempo, jogo de } \\
\text { palavras, slogans, teasers etc }\end{array}$ \\
\hline & Remuneração & $\begin{array}{l}\text { benefícios relacionados a promoções, descontos, cupons, } \\
\text { concursos, prêmios, emprego etc }\end{array}$ \\
\hline \multirow{5}{*}{$\begin{array}{l}\text { Interatividade / } \\
\text { Vivacidade }\end{array}$} & Texto & $\begin{array}{l}\text { Texto podendo conter letras, números e caracteres especiais } \\
\text { como emoticons por exemplo }\end{array}$ \\
\hline & Foto & Uma imagem estática \\
\hline & Álbum & Um conjunto de imagens estáticas \\
\hline & Video c/ som & Imagem com movimento porém com som \\
\hline & Links & $\begin{array}{l}\text { referência aos dados que o leitor pode seguir diretamente } \\
\text { clicando, tocando ou passando o cursor por cima }\end{array}$ \\
\hline \multirow{3}{*}{ Data } & Período do dia & $\begin{array}{l}\text { Manhã (6:00 - 11:59), Tarde (12:00 - 17:59), Noite (18:00 - 23:59), } \\
\text { Madrugada (0:00 - 5:59) }\end{array}$ \\
\hline & Dia da semana & Segunda, Terça, Quarta, Quinta, Sexta, Sábado, Domingo \\
\hline & Mês & Mês do ano \\
\hline
\end{tabular}

Quadro 2 - Categorias iniciais previstas pelo autor

Após a exploração do material o guia final de codificação ficou como o abaixo quadro 3 com a inclusão de vídeos sem som e a abertura de links em hyperlink, hashtag e botão de ação. 


\begin{tabular}{|c|c|c|}
\hline Categoria & Subcategoria & Descrição \\
\hline \multirow{3}{*}{$\begin{array}{l}\text { Usos e } \\
\text { Gratificações }\end{array}$} & Informativo & Informação útil ligada a produto, a marca, ou a empresa \\
\hline & Entretenimento & $\begin{array}{l}\text { conteúdo engraçado, divertido, lúdico, passatempo, jogo de } \\
\text { palavras, slogans, teasers etc }\end{array}$ \\
\hline & Remuneração & $\begin{array}{l}\text { benefícios relacionados a promoções, descontos, cupons, } \\
\text { concursos, prêmios, emprego etc }\end{array}$ \\
\hline \multirow{9}{*}{$\begin{array}{l}\text { Interatividade / } \\
\text { Vivacidade }\end{array}$} & Texto & $\begin{array}{l}\text { Texto podendo conter letras, números e caracteres } \\
\text { especiais como emoticons por exemplo }\end{array}$ \\
\hline & Foto & Uma imagem estática \\
\hline & Álbum & Um conjunto de imagens estáticas \\
\hline & Video s/ som & Imagem com movimento porém sem som \\
\hline & Video $\mathrm{c} / \mathrm{som}$ & Imagem com movimento porém com som \\
\hline & Links & \\
\hline & - Hyperlink & $\begin{array}{l}\text { é uma referência a novos dados normalmente } \\
\text { complementares ao post. Normalmente conteúdo da marca }\end{array}$ \\
\hline & - hashtag & $\begin{array}{l}\text { contenham o mesmo descritivo da referência podendo ser } \\
\text { da marca ou não }\end{array}$ \\
\hline & - Botão & $\begin{array}{l}\text { é um botão que gera alguma ação como "curtir uma } \\
\text { página" ou "saiba mais" }\end{array}$ \\
\hline \multirow{3}{*}{ Data } & Período do dia & $\begin{array}{l}\text { Manhã (6:00 - 11:59), Tarde (12:00 - 17:59), Noite (18:00 - } \\
\text { 23:59), Madrugada (0:00 - 5:59) }\end{array}$ \\
\hline & Dia da semana & Segunda, Terça, Quarta, Quinta, Sexta, Sábado, Domingo \\
\hline & Mês & Mês do ano \\
\hline
\end{tabular}

Quadro 3 - Categorias finais criadas pelo autor

\subsubsection{Tratamento dos resultados, inferências e interpretação}

Por fim, a última etapa da análise - identificação das unidades de registro nos documentos - consiste no tratamento estatístico dos resultados, permitindo que o pesquisador destaque as informações fornecidas para a análise. Nessa pesquisa foi utilizado a contagem por frequência simples.

Na Figura 9, inserida no final deste capítulo, encontra-se um resumo da análise de conteúdo proposto por Bardin (2009). 
PRÉ-ANÁLISE

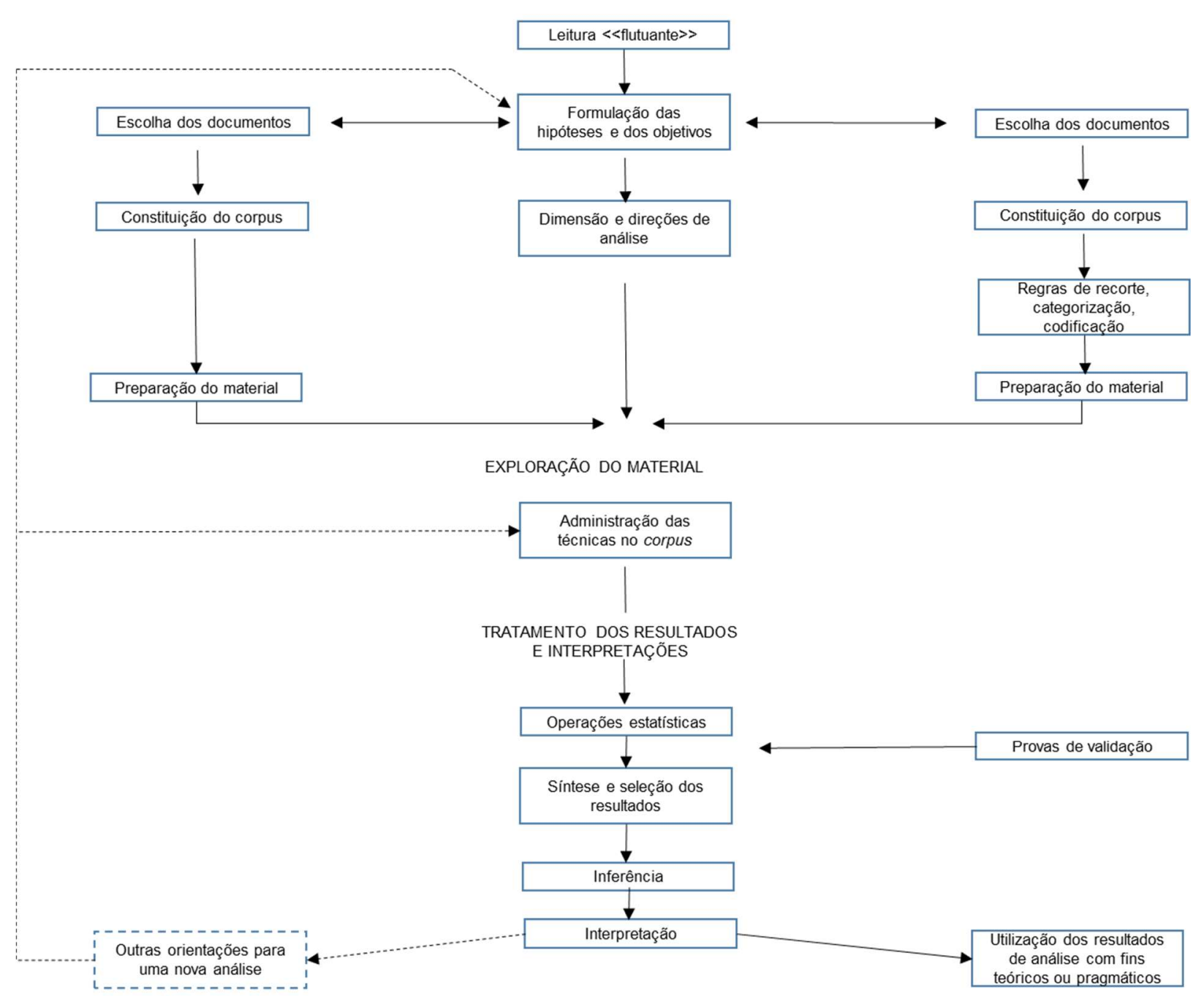

Figura 9 - Fluxo da análise de conteúdo proposto por Bardin (2009) 


\section{RESULTADOS}

Foram avaliados 906 posts coletados no período de 01 de julho de 2016 a 01 de janeiro de 2017. Foram analisados elementos de interatividade, vivacidade, tipos de conteúdo, momentos em que o post foi veiculado como período do dia, dia da semana e mês do ano. Primeiro uma visão geral das marcas e depois por marca.

\subsection{Visão Geral}

As marcas variaram bastante a frequência com que postaram seus conteúdos. As estratégias de comunicação em relação a frequência variaram bastante de marca para marca. Entre a marca com maior frequência Caixa Econômica Federal com 326 posts e a com menor frequência, Citibank com 46 posts a diferença foi de 7 vezes. No período analisado, a CEF postou uma média de 1 post a cada 14 horas enquanto o Citibank postava algo a cada 4 dias em média. Os outros bancos tiveram em média, uma frequência de postagem que ficou entre 1 e 2 dias. Percebe-se assim que a comunicação das marcas com os seus fãs variou de constante, diário a algo mais esporádico, pontual.

\begin{tabular}{|l|r|r|}
\hline Banco & Qtde & Percentual \\
\hline Itaú & 149 & $16 \%$ \\
\hline Bradesco & 97 & $11 \%$ \\
\hline Banco do Brasil & 170 & $19 \%$ \\
\hline Caixa Econômica Federal & 326 & $36 \%$ \\
\hline Santander & 118 & $13 \%$ \\
\hline Citibank & 46 & $5 \%$ \\
\hline Total & 906 & $100 \%$ \\
\hline Média & 151 & \\
\hline
\end{tabular}

Tabela 4 - Quantidade de posts por banco

No período analisado, as marcas retiraram 84 posts das suas newsfeeds. Caixa Econômica Federal foi a marca que mais retirou posts da sua página com 47 posts representando $56 \%$ dos posts. Muitos posts retirados eram referentes as Olimpíadas/Paraolimpíadas, produtos de crédito e atualização de foto de perfil/capa. A segunda marca que mais posts retirou de sua página foi o 
Itaú com 14 posts o que representou $17 \%$ dos posts que as marcas retiraram de suas páginas. Itaú mais retirou da sua newsfeed foram atualizações da foto da capa e do seu aplicativo para celular. Veja exemplos de posts retirados nas figuras 10 e 11.

\begin{tabular}{|l|r|r|}
\hline Banco & Qtde & Percentual \\
\hline Itaú & 14 & $17 \%$ \\
\hline Bradesco & 4 & $5 \%$ \\
\hline Banco do Brasil & 6 & $7 \%$ \\
\hline Caixa Econômica Federal & 47 & $56 \%$ \\
\hline Santander & 10 & $12 \%$ \\
\hline Citibank & 3 & $4 \%$ \\
\hline Total & 84 & $100 \%$ \\
\hline Média & 14 & \\
\hline
\end{tabular}

Tabela 5 - Quantidade de posts retirados por banco

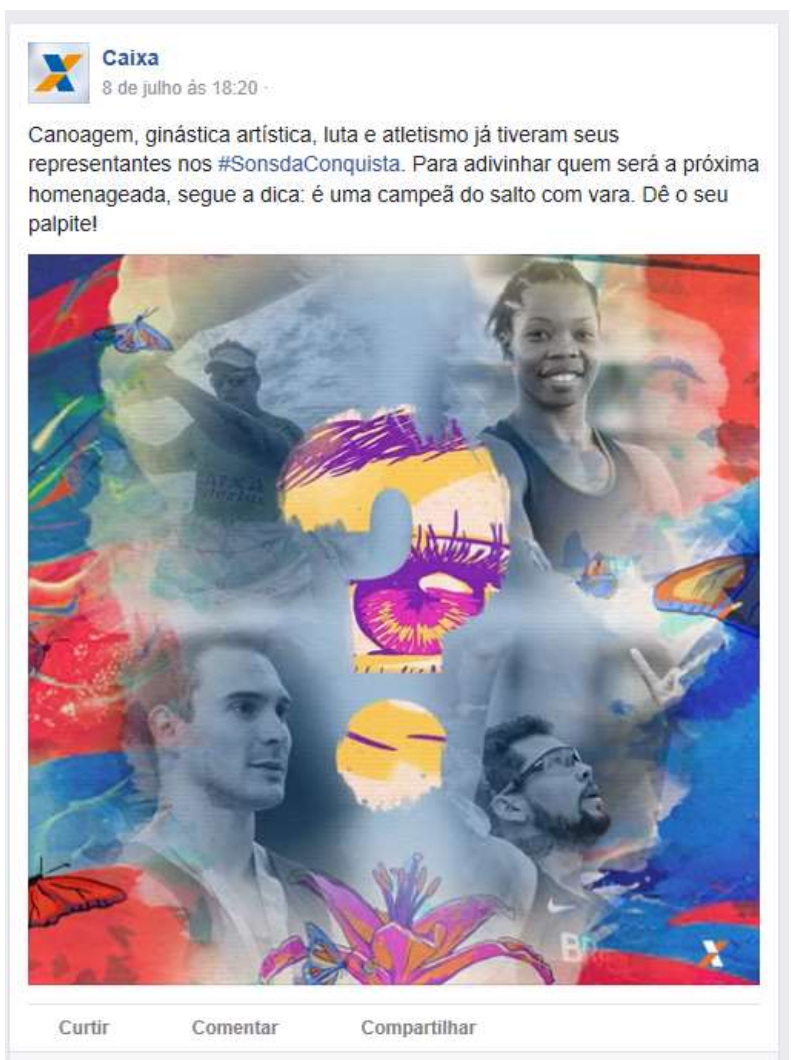

Figura 10- post retirado da página da CEF 
Itaú Itaú

Você já pede comida pelo app iFood delivery? Já pode ir ao banco também

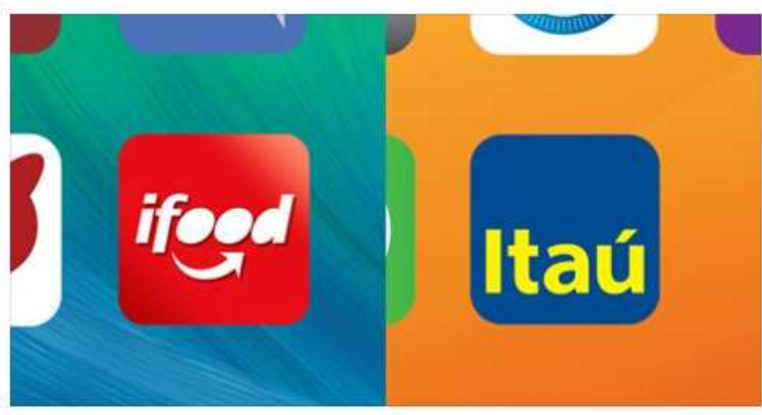

Curtir Comentar Compartilhar

Figura 11 - Post retirado da página do Itaú

No período avaliado todos os bancos aumentaram as suas bases tendo o conjunto das seis marcas crescido $10 \%$ entre 01/07/16 e 01/01/17. Contudo, o crescimento não foi parecido entre as marcas. Das seis marcas, quatro tiveram crescimento até $5 \%$ no período e duas tiveram crescimento bem acima da média. Os bancos que mais aumentaram suas bases foram Santander com $58 \%$ de aumento, seguido da Caixa Econômica Federal com 23\%.

\begin{tabular}{|c|c|c|c|c|c|c|}
\hline Marca & $\begin{array}{r}\text { Quantidade de fãs } \\
01 / 07 / 2016\end{array}$ & Part. (\%) & $\begin{array}{l}\text { Quantidade de } \\
\text { fãs } \\
01 / 01 / 2017\end{array}$ & Part. (\%) & Crescimento & $\begin{array}{c}\text { Evolução } \\
(\%)\end{array}$ \\
\hline Itaú & 8.346 .362 & $42 \%$ & 8.611 .635 & $40 \%$ & 265.273 & $3 \%$ \\
\hline Bradesco & 4.928 .753 & $25 \%$ & 5.028 .832 & $23 \%$ & 100.079 & $2 \%$ \\
\hline Banco do Brasil & 2.267 .295 & $11 \%$ & 2.371 .825 & $11 \%$ & 104.530 & $5 \%$ \\
\hline Caixa Econômica Federal & 1.953 .058 & $10 \%$ & 2.411 .495 & $11 \%$ & 458.437 & $23 \%$ \\
\hline Santander & 1.688 .461 & $9 \%$ & 2.675 .994 & $12 \%$ & 987.533 & $58 \%$ \\
\hline Citibank & 644.547 & $3 \%$ & 659.366 & $3 \%$ & 14.819 & $2 \%$ \\
\hline Total & 19.828 .476 & $100 \%$ & 21.759 .147 & $100 \%$ & 1.930 .671 & $10 \%$ \\
\hline
\end{tabular}

Fonte: Facebook

Tabela 6 - Evolução da quantidade de fãs das marcas no Facebook

\subsection{Textos, Fotos, Álbuns, Vídeos e links}

Dos elementos mais utilizados pelas marcas para gerar interatividade e/ou vivacidade o uso de links com texto combinados com foto e vídeo com som foram os mais frequentes nas estratégias de comunicação das marcas com 
$40 \%$ (359) posts e $22 \%$ (200) posts, respectivamente. O uso de texto foi aplicado em 95\% (857) dos posts. Tirando os posts que eram referentes a atualização do perfil 6\% (13) ou atualização da capa 16\% (35), todos os demais posts continham texto. O uso de links foi de $76 \%$ (692) posts. O uso de fotos foi de 56\% (510) dos posts. Vídeo com som foi utilizado em 241 (27\%) dos posts. Vídeo sem som apareceu em 13\% (117) dos posts. Por fim, álbuns foi utilizado em apenas 4\% (37) dos posts. Portanto, o uso de algum tipo de imagem seja ela no formato de foto ou álbum, ou no formato de vídeo com ou sem som, praticamente correspondiam a $100 \%$ da amostra com a exceção de um único post que continha apenas texto. Além do fato das imagens serem um recurso mais vívido para atrair a atenção do fã da página, existe uma outra explicação que pode influenciar a decisão das grandes marcas em utilizar recursos mais vívidos. Segundo Waller (2016) o algoritmo do Facebook penaliza posts que não usam imagem.

\begin{tabular}{|l|r|r|}
\hline Tipo de Elementos & Possui & Percentual \\
\hline Só texto & 1 & $0 \%$ \\
\hline Só foto & 48 & $5 \%$ \\
\hline Só video c/som & 1 & $0 \%$ \\
\hline Texto + foto & 103 & $11 \%$ \\
\hline Texto + Álbum & 4 & $0 \%$ \\
\hline Texto + Video s/som & 17 & $2 \%$ \\
\hline Texto + Video c/som & 40 & $4 \%$ \\
\hline Texto + foto + link & 359 & $40 \%$ \\
\hline Texto + Álbum + link & 33 & $4 \%$ \\
\hline Texto + Video s/som + link & 100 & $11 \%$ \\
\hline Texto + Video c/som + link & 200 & $22 \%$ \\
\hline Total Posts & 906 & $100 \%$ \\
\hline
\end{tabular}

Tabela 7 - Posts com elementos de interatividade / vivacidade

Se subdividirmos a classificação de links em hyperlinks, hashtags e botões (para curtir uma página, por exemplo), existe uma presença maior para links $(60 \%)$ dos posts, que direcionam o usuário para uma complementação da informação contida no post, seguida por hashtags (40\%) que direcionam o membro para todas os posts relacionados com a hashtag sendo eles criados 
pela marca ou não. Por fim, os botões que podiam ser do tipo "curtir uma página" de outra marca ou um botão do tipo "saiba mais", por exemplo, apareceram em apenas $3 \%$ dos posts.

\begin{tabular}{|l|r|r|}
\hline Tipo de Elemento & Possui & Percentual \\
\hline Links & 542 & $60 \%$ \\
\hline Hashtags & 396 & $44 \%$ \\
\hline Botões & 30 & $3 \%$ \\
\hline Nada & 214 & $24 \%$ \\
\hline Total Posts & $\mathbf{9 0 6}$ & $\mathbf{1 0 0 \%}$ \\
\hline
\end{tabular}

Tabela 8 - Posts por tipos de elementos de interatividade / vivacidade

Além da presença de links na maioria dos posts, nos textos as frases antes dos links continham verbos que sugeriam alguma ação por parte dos usuários para buscar mais informações nos links. Os posts usavam verbos como "acesse", "veja”, “aproveite”, "conheça”, "descubra”, leia”, “consulte”, “confira”, "participe”, "acompanhe" etc. Na figura 12 um exemplo de frase seguida do link.

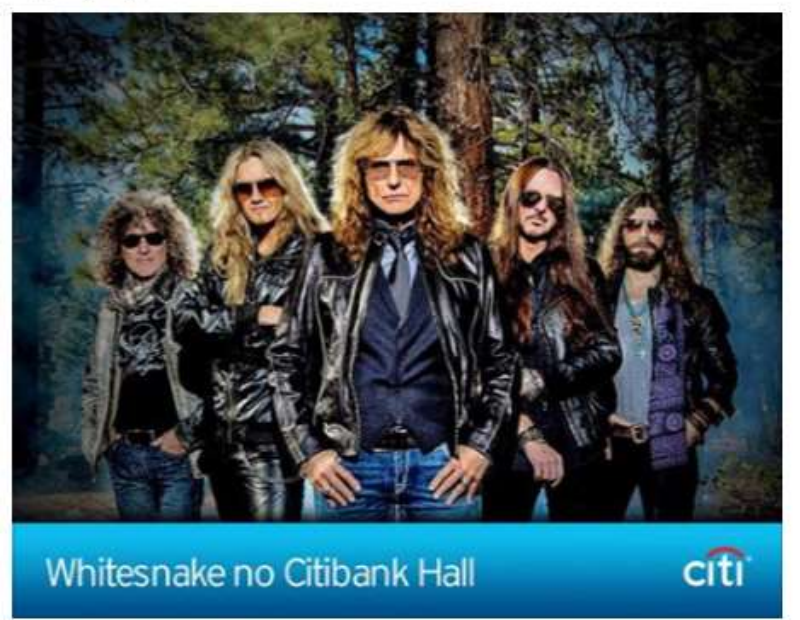

Curtir Comentar Compartilhar

Figura 12 - Exemplo de frase de ação seguida de link 
Quanto ao número de elementos interativos, $47 \%$ (426) posts possuíam apenas 1 elemento de interatividade (link, hashtag ou botão), 28\% (256) posts possuíam dois elementos, $1 \%$ (30) posts possuíam os três tipos de interatividade. Em 24\% (214) dos posts não havia nenhum dos três tipos de elemento, ou seja, 76\% (692) posts continham pelo menos um desses elementos, ou seja, mais de 3 posts em cada 4 possuíam algum desses elementos que possibilitavam o usuário interagir com o post como, por exemplo, ir a outra página ou executar a inscrição em outra página de marca.

\begin{tabular}{|l|r|r|}
\hline Qtde de Elementos & Possui & Percentual \\
\hline 1 Elemento & 426 & $47 \%$ \\
\hline 2 Elementos & 256 & $28 \%$ \\
\hline 3 Elementos & 10 & $1 \%$ \\
\hline Nenhum & 214 & $24 \%$ \\
\hline Total Posts & $\mathbf{9 0 6}$ & $\mathbf{1 0 0 \%}$ \\
\hline
\end{tabular}

Tabela 9 - Quantidade de elementos de interatividade/ vivacidade no mesmo post

Dos 214 posts sem elementos de interação em 22\% (48) posts, eram de foto do perfil $6 \%$ (13) e $16 \%$ (35) eram foto da capa.

\begin{tabular}{|l|r|r|}
\hline Qtde de Elementos & Possui & Percentual \\
\hline Foto do Perfil & 13 & $6 \%$ \\
\hline Foto da Capa & 35 & $16 \%$ \\
\hline Nenhum & $\mathbf{2 1 4}$ & $\mathbf{1 0 0 \%}$ \\
\hline
\end{tabular}

Tabela 10 - Tipo de post sem interatividade

Porém, junto com a foto de atualização do perfil ou da capa é possível escrever textos como na figura 13, onde além de divulgar a atualização da capa a marca também escreve um texto sugerindo o usuário a acessar o link. 
citı

Citi Brasil atualizou a foto da capa dele.

Veja como o Citi está ajudando no progresso do país

citi.com.br/progresso

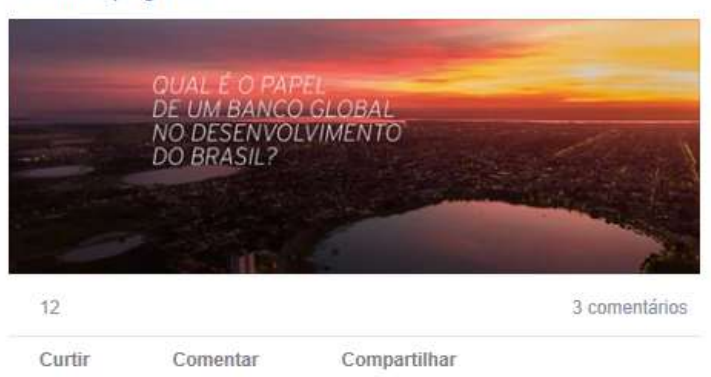

Figura 13 - Texto junto com atualização da foto de capa

Posts com conteúdo informativo foram a maioria nos posts das marcas aparecendo em 58\% (528) dos posts. Em seguida entretenimento com $32 \%$ (293) dos posts. Por fim, remuneração com 9\% (85) dos posts. Todos os bancos pesquisados têm sites com muita informação sobre os produtos, serviços e sobre a empresa. Ainda assim, a maior parte das marcas publicam conteúdos de natureza informativa em suas páginas.

\begin{tabular}{|l|r|r|}
\hline Tipo de Conteúdo & Possui & Percentual \\
\hline Informativo & 528 & $58 \%$ \\
\hline Entretenimento & 293 & $32 \%$ \\
\hline Remuneração & 85 & $9 \%$ \\
\hline Total Posts & $\mathbf{9 0 6}$ & $\mathbf{1 0 0 \%}$ \\
\hline
\end{tabular}

Tabela 11 - Tipos de conteúdo

O período mais utilizado pelas marcas de bancos foi o período da tarde (12:00 até $17: 59$ ) com $38 \%$ dos posts publicadas nesse período. Logo depois vieram os períodos da noite e da manhã com quantidade de publicações muito parecidos. O período da madrugada quase não foi utilizado, exceções feitas a oportunidades de momento como a celebração da conquista do ouro pela seleção brasileira de futebol (figura 14) e publicadas antes da $1 \mathrm{~h}$ da manhã. 


\begin{tabular}{|l|r|r|}
\hline Período do dia & Qtde & Percentual \\
\hline Manhã & 274 & $30 \%$ \\
\hline Tarde & 348 & $38 \%$ \\
\hline Noite & 280 & $31 \%$ \\
\hline Madrugada & 4 & $0 \%$ \\
\hline Total Posts & $\mathbf{9 0 6}$ & $\mathbf{1 0 0 \%}$ \\
\hline
\end{tabular}

Tabela 12 - Frequência de posts por dia da semana

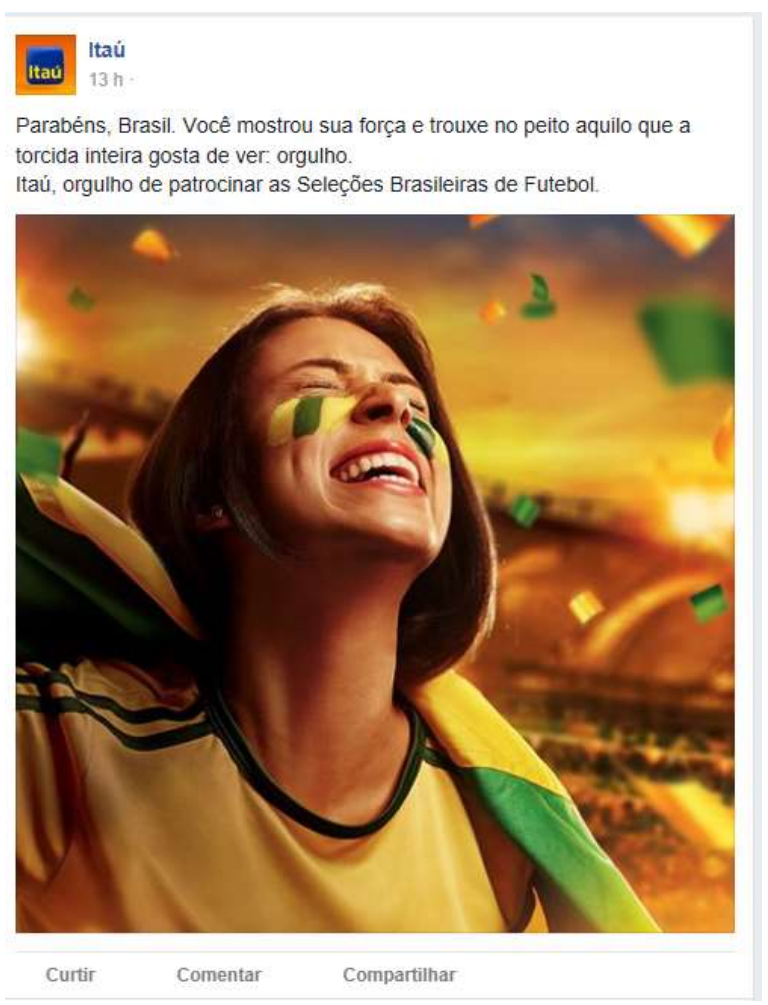

Figura 14 - celebração pela conquista do ouro

Os posts das marcas tiveram uma frequência maior no meio da semana (Quarta, Quinta e Sexta-Feira). Os finais de semana tiveram a menor frequência de publicações. 


\begin{tabular}{|l|r|r|}
\hline Dia da semana & \multicolumn{1}{|c|}{ Qtde } & Percentual \\
\hline Segunda & 135 & $15 \%$ \\
\hline Terça & 138 & $15 \%$ \\
\hline Quarta & 151 & $17 \%$ \\
\hline Quinta & 156 & $17 \%$ \\
\hline Sexta & 205 & $23 \%$ \\
\hline Sábado & 62 & $7 \%$ \\
\hline Domingo & 59 & $7 \%$ \\
\hline Total Posts & $\mathbf{9 0 6}$ & $\mathbf{1 0 0 \%}$ \\
\hline
\end{tabular}

Tabela 13 - Frequência de posts por período

As marcas concentraram as suas publicações nos meses de Julho-AgostoSetembro e no mês de Dezembro. Agosto-Setembro foram os meses das Olimpíadas e das Paraolimpíadas. Dezembro foi época onde as marcas exploraram as datas festivas.

\begin{tabular}{|l|r|r|}
\hline Meses & \multicolumn{1}{|c|}{ Qtde } & Percentual \\
\hline Junho & 7 & $1 \%$ \\
\hline Julho & 169 & $19 \%$ \\
\hline Agosto & 179 & $20 \%$ \\
\hline Setembro & 164 & $18 \%$ \\
\hline Outubro & 117 & $13 \%$ \\
\hline Novembro & 111 & $12 \%$ \\
\hline Dezembro & 159 & $18 \%$ \\
\hline Total Posts & $\mathbf{9 0 6}$ & $\mathbf{1 0 0 \%}$ \\
\hline
\end{tabular}

Tabela 14 - Frequência dos posts mensal

A fixação dos posts no topo da página foi um recurso pouco explorado pelas marcas. No período apenas 2\% (16) posts foram fixados. Entretanto, alguns posts permaneceram por longo período no topo da página como o do $\mathrm{BB}$, figura 14 , que até o dia final da coleta de dados permanecia fixado (30/08 a 31/12). Itaú foi a marca que mais utilizou esse recurso com um total de 10 posts fixados. CEF usou 3 vezes o recurso, Banco do Brasil utilizou 2 vezes. Santander 1 única vez. Bradesco não fixou nenhum post no período. 


\begin{tabular}{|l|r|r|}
\hline & \multicolumn{1}{|c|}{ Qtde } & Percentual \\
\hline Post fixado & 16 & $\mathbf{2 \%}$ \\
\hline Total Posts & $\mathbf{9 0 6}$ & $\mathbf{1 0 0 \%}$ \\
\hline
\end{tabular}

Tabela 15 - Posts fixados no topo da página

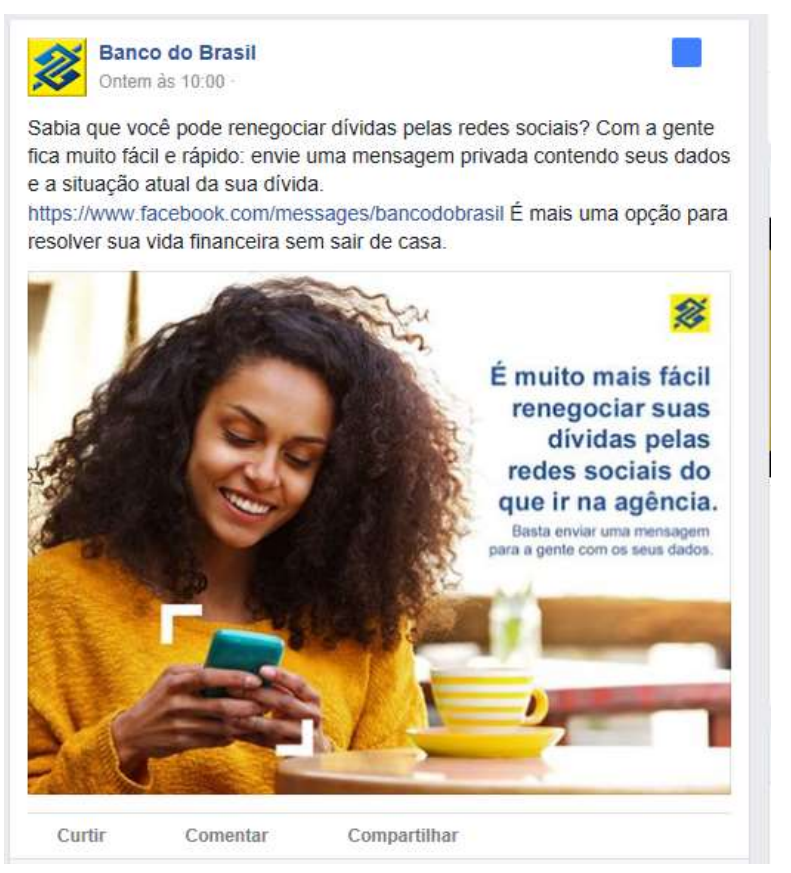

Figura 15 - post do BB fixado do dia 31/08/16 e permanecia fixado em 31/12/16

Dos posts fixados no período os assuntos mais recorrentes foram de entretenimento com 9 posts (5 do Itaú com o tema da educação), seguido de informativo com 7 posts. Remuneração não teve nenhum post fixado.

\begin{tabular}{|l|r|r|}
\hline Posts fixados & \multicolumn{1}{|c|}{ Qtde } & Percentual \\
\hline Informativo & 7 & $44 \%$ \\
\hline Entretenimento & 9 & $56 \%$ \\
\hline Remuneração & 0 & $0 \%$ \\
\hline Total posts fixados & $\mathbf{1 6}$ & $\mathbf{1 0 0 \%}$ \\
\hline
\end{tabular}

Tabela 16 - Posts fixados no topo da página por tipo de conteúdo

Exemplo de post fixado de entretenimento na figura abaixo. 


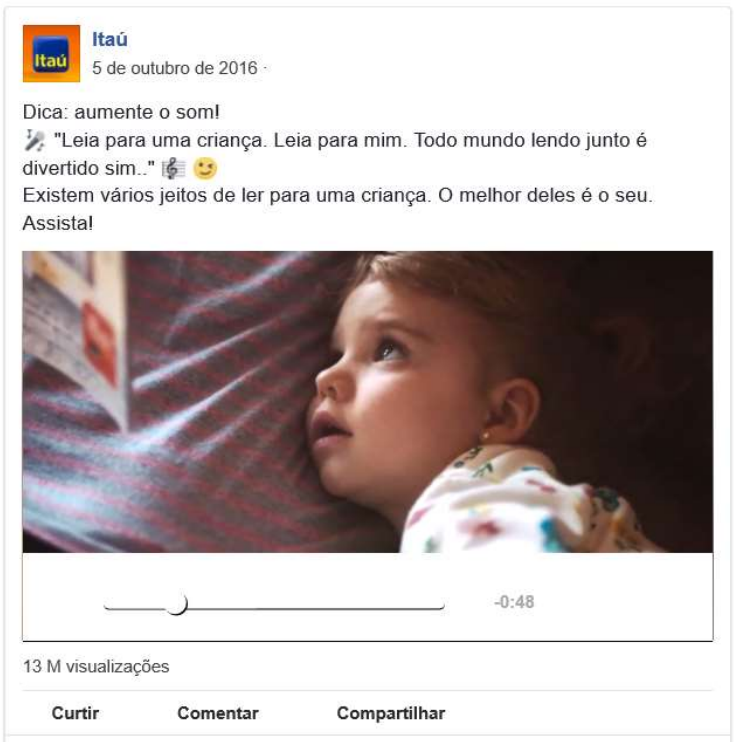

Figura 16 - Post fixado de entretenimento

\subsection{Descrição das marcas analisadas}

Das marcas analisadas, em 2017, a mais nova, Bradesco, possui 74 anos de existência e a mais antiga, Caixa Econômica Federal, 209 anos, o que demonstra a tradição dessas marcas. Quanto a origem são 4 bancos brasileiros e 2 estrangeiros. Por fim, em relação ao capital, 4 são bancos de capital privado e 2 de capital público.

\begin{tabular}{|l|c|l|l|}
\hline \multicolumn{1}{|c|}{ Marca } & $\begin{array}{c}\text { Ano de } \\
\text { fundação }\end{array}$ & Origem & Capital \\
\hline Itaú & 1.924 & Brasileiro & Privado \\
\hline Bradesco & 1.943 & Brasileiro & Privado \\
\hline Banco do Brasil & 1.808 & Brasileiro & Público \\
\hline Santander & 1.857 & Espanhol & Privado \\
\hline Caixa Econômica Federal & 1.861 & Brasileiro & Público \\
\hline Citibank & 1.812 & Americano & Privado \\
\hline
\end{tabular}

Quadro 4 - Características das marcas 
A tabela 17 mostra o porte das marcas selecionadas em relação ao setor financeiro brasileiro. De acordo com dados do Banco Central de junho de 2014, os 6 bancos selecionados para esse estudo representavam $68 \%$ de todos os Ativo Totais do mercado financeiro brasileiro e $65 \%$ de todo lucro líquido desse mercado.

\begin{tabular}{|l|r|r|r|r|}
\multicolumn{1}{|c|}{ Marca } & \multicolumn{1}{c}{$\begin{array}{c}\text { Ativos Totais } \\
\text { (jun/2014) }\end{array}$} & Part. (\%) & $\begin{array}{c}\text { Lucro Líquido } \\
\text { (jun/2014) }\end{array}$ & Part. (\%) \\
\hline Itaú & $\mathrm{R} \$ 1.029 .025 .053,00$ & $15 \%$ & $\mathrm{R} \$ 8.317 .679,00$ & $21 \%$ \\
\hline Bradesco & $\mathrm{R} \$ 793.507 .842,00$ & $12 \%$ & $\mathrm{R} \$ 7.234 .300,00$ & $18 \%$ \\
\hline Banco do Brasil & $\mathrm{R} \$ 1.303 .651 .713,00$ & $19 \%$ & $\mathrm{R} \$ 5.706 .040,00$ & $14 \%$ \\
\hline Santander & $\mathrm{R} \$ 502.784 .192,00$ & $7 \%$ & $\mathrm{R} \$ 1.092 .942,00$ & $3 \%$ \\
\hline Caixa Econômica Federal & $\mathrm{R} \$ 963.315 .687,00$ & $14 \%$ & $\mathrm{R} \$ 3.389 .467,00$ & $9 \%$ \\
\hline Citibank & $\mathrm{R} \$ 53.366 .415,00$ & $1 \%$ & $\mathrm{R} \$ 107.412,00$ & $0 \%$ \\
\hline Soma 6 bancos & $\mathrm{R} \$ 4.645 .650 .902,00$ & $68 \%$ & $\mathrm{R} \$ 25.847 .840,00$ & $65 \%$ \\
\hline Total Bancos & $\mathrm{R} \$ 6.857 .637 .903,00$ & $100 \%$ & $\mathrm{R} \$ 39.644 .284,00$ & $100 \%$ \\
\hline
\end{tabular}

Tabela 17 - Dados financeiros, Fonte: Bacen, jun/2014

Após essa breve descrição das marcas vamos a uma série de análises comparativas das marcas.

\subsection{Conteúdo das mensagens dos posts}

Dos três tipos de conteúdo, de maneira geral a mais utilizada é o conteúdo de cunho informativo (58\%) seguido de Entretenimento (32\%) e Remuneração (9\%). Em uma análise individual percebe-se que Bradesco $(77 \%)$ e Itaú $(65 \%)$ priorizaram o conteúdo de entretenimento abordando mais temas do cotidiano ou de eventos. Itaú abordando temas ligados a educação e a cultura. Bradesco, por ser patrocinador, divulgando as Olimpíadas e as Paraolimpíadas. Estes bancos mais focados em criar relacionamento com a marca, Já as demais marcas, Banco do Brasil (76\%), CEF (72\%), Santander (69\%) e Citibank (54\%) focam no conteúdo informativo mais direcionado aos seus produtos e serviços. Ainda a destacar que Citibank (39\%) e Santander (19\%) são os bancos que mais 
postam conteúdos de remuneração como por exemplo, descontos e benefícios no cartão de crédito.

\begin{tabular}{|c|c|c|c|c|c|c|c|c|c|c|c|c|c|c|}
\hline & \multicolumn{2}{|c|}{ Geral } & \multicolumn{2}{|c|}{ Itaú } & \multicolumn{2}{|c|}{ Bradesco } & \multicolumn{2}{|c|}{ Banco do Brasil } & \multicolumn{2}{|c|}{ CEF } & \multicolumn{2}{|c|}{ Santander } & \multicolumn{2}{|c|}{ Citibank } \\
\hline Tipo de Conteúdo & Possui & Percent. & Possui & \begin{tabular}{|l|} 
Percent. \\
\end{tabular} & Possui & \begin{tabular}{|l|} 
Percent. \\
\end{tabular} & Possui & Percent. & Possui & Percent. & Possui & Percent. & Possui & Percent. \\
\hline Informativo & 528 & $58 \%$ & 40 & $27 \%$ & 18 & $19 \%$ & 130 & $76 \%$ & 234 & $72 \%$ & 81 & $69 \%$ & 25 & $54 \%$ \\
\hline Entretenimento & 293 & $32 \%$ & 97 & $65 \%$ & 75 & $77 \%$ & 14 & $8 \%$ & 89 & $27 \%$ & 15 & $13 \%$ & 3 & $7 \%$ \\
\hline \begin{tabular}{|l|} 
Remuneração \\
\end{tabular} & 8 & $9 \%$ & 12 & $8 \%$ & 4 & $4 \%$ & 26 & $15 \%$ & 3 & $1 \%$ & 22 & $19 \%$ & 18 & $39 \%$ \\
\hline Total Posts & 906 & $100 \%$ & 149 & $100 \%$ & 97 & $100 \%$ & 170 & $100 \%$ & 326 & $100 \%$ & 118 & $100 \%$ & 46 & $100 \%$ \\
\hline
\end{tabular}

Tabela 18 - Tipos de conteúdo

Caixa

12 de dezembro de 2016

Pagar conta não precisa ser complicado. É por isso que na Caixa você pode usar o internet banking, o Aplicativo Caixa, as lotéricas e os

correspondentes Caixa Aqui. E, se quiser ainda mais facilidade, cadastre o

débito automático das suas contas. É seguro e prático! *

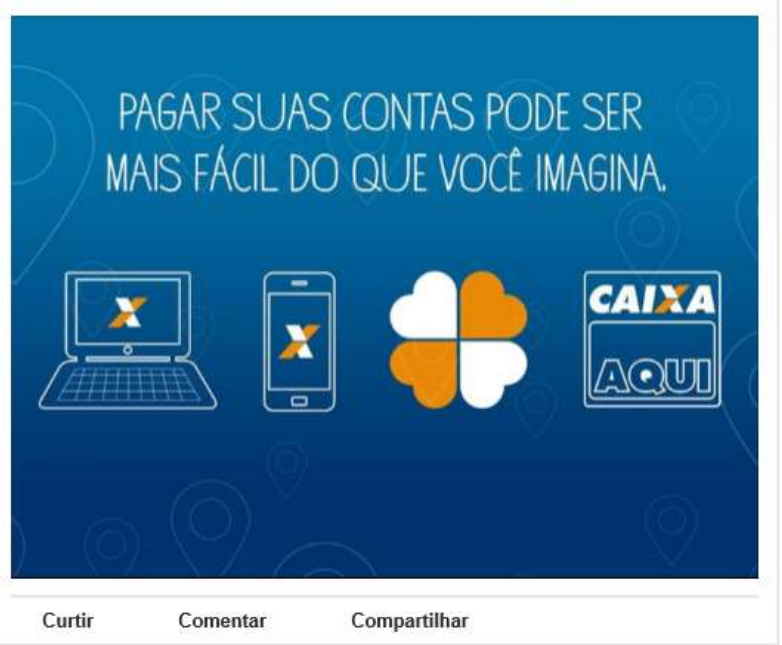

Figura 17 - Post informativo da CEF 
De Caco Barcellos a Karl OveKnausgård: veja tudo que aconteceu no $2^{\circ}$ dia da Flip - Festa Literária Internacional de Paraty Incentivar a cultura \#issomudaomundo

Acompanhe a cobertura da \#Flip216 pelo nosso Snapchat. Siga Itau

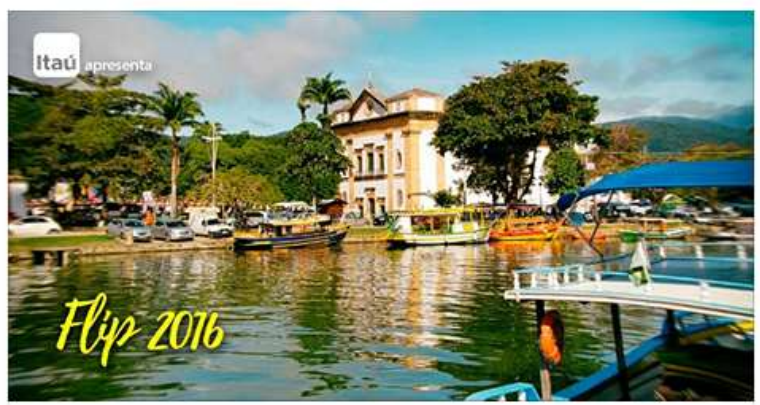

Flip 2016: acompanhe a cobertura do evento

De 29 de junho a 3 de julho, acontece a $14^{2}$ edição da Festa Literária Internacional de Paraty (Flip). Neste especial você encontra um.

MEDIUM COM [ POR ITAU

Curtir Comentar Compartilhar

Figura 18 - Post de entretenimento do Itaú

Bradesco

$1 \mathrm{~h} \cdot \mathrm{b}$

Gente de todo canto do mundo reunida em um único lugar e vivendo cada experiência de maneira intensa. O escritor Pedrinho Fonseca conheceu

algumas dessas pessoas no Parque Olímpico e apresenta agora a vocês em nosso Medium. \#agoraéBRA

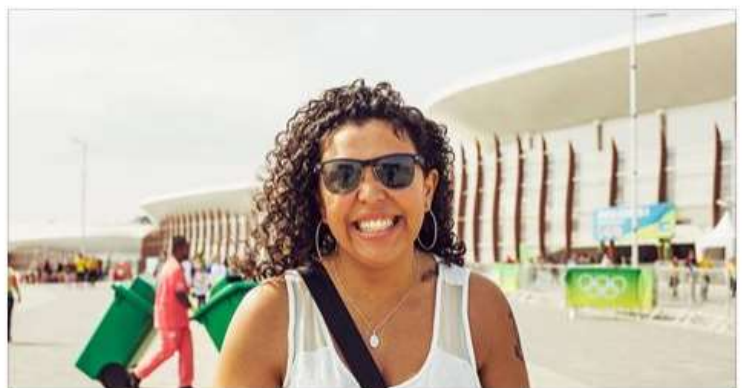

$\mathrm{O}$ que eu vi

Por Pedrinho Fonseca

MEDIUM.COM I POR BRADESCO

Curtir Comentar Compartilhar

Figura 19 - Post de entretenimento do Bradesco 


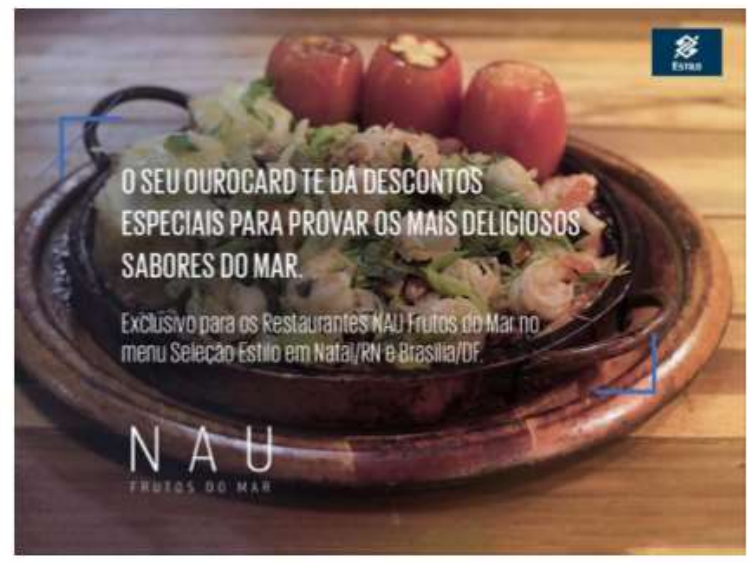

Curtir Comentar Compartilhar

Figura 20 - post de remuneração do BB

\subsection{Interatividade e vivacidade dos posts}

Em termos de elementos que impactam a interatividade e/ ou a vivacidade dos posts as marcas têm estratégias com algumas diferenças. Itaú utiliza mais posts com texto, link e vídeo com som (41\%) e posts com texto, link e foto (37\%) - uma preferência por imagens animadas com som e estáticas.

Bradesco prefere mais posts com texto, link e vídeo com som (47\%) e texto, link e vídeo sem som (20\%) - preferência por imagens animadas com ou sem som. Segundo Waller (2016), GIFs (imagens animadas sem som) funcionam bem com audiência jovem. Pode ser uma estratégia do Bradesco para atingir um público mais jovem. Banco do Brasil usa mais texto, link e foto (62\%) e texto, link e vídeo com som (14\%) - uma preferência por imagens animadas e estáticas. CEF utiliza mais texto, link e foto (36\%) e texto e foto (22\%) preferência por foto com ou sem link. Santander usa mais texto, link e foto (36\%) e texto, link e vídeo com som (29\%) - uma preferência por imagens animadas e estáticas. Citibank prefere mais posts com texto, link e foto $(57 \%)$ e texto, link e álbum (17\%) - uma preferência por imagens estáticas. Percebe-se que as marcas de uma maneira geral preferem o uso de mais de um elemento de interatividade e/ou vivacidade. Nota-se a presença na maior parte dos casos 
de texto, link e algum tipo de imagem animada (com ou sem som) ou estática. O tipo mais usado é o post com texto, link e foto. Neste tipo de post, Banco do Brasil (62\%) e Citibank (57\%) são os que mais utilizam estes recursos. 0 segundo tipo de post mais utilizado pelas marcas é o que combina texto, link e vídeo com som. Neste tipo de post, Bradesco (47\%) e Itaú (41\%) são os que mais utilizam essa estratégia, ou seja, são as marcas que utilizam mais elementos que geram interatividade e vivacidade. Por outro lado, o segundo tipo de post mais utilizado pela CEF - posts com texto e foto (22\%), são posts considerados de baixa interatividade. Podemos concluir que as marcas utilizam bastante elementos para suscitar a interatividade e a vivacidade.

\begin{tabular}{|c|c|c|c|c|c|c|c|c|c|c|c|c|c|c|}
\hline \multirow[b]{2}{*}{ Tipo de Elementos } & \multicolumn{2}{|c|}{ Geral } & \multicolumn{2}{|c|}{ Itaú } & \multicolumn{2}{|c|}{ Bradesco } & \multicolumn{2}{|c|}{ Banco do Brasil } & \multicolumn{2}{|c|}{ CEF } & \multicolumn{2}{|c|}{ Santander } & \multicolumn{2}{|c|}{ Citibank } \\
\hline & Possui & Percent. & Possui & Percent. & Possui & Percent. & Possui & Percent. & Possui & \begin{tabular}{|l|} 
Percent. \\
\end{tabular} & Possui & Percent. & Possui & Percent. \\
\hline Só texto & 1 & $0 \%$ & 0 & $0 \%$ & 0 & $0 \%$ & 0 & $0 \%$ & 1 & $0 \%$ & 0 & $0 \%$ & 0 & $0 \%$ \\
\hline Só foto & 48 & $5 \%$ & 6 & $4 \%$ & 7 & $7 \%$ & 3 & $2 \%$ & 30 & $9 \%$ & 0 & $0 \%$ & 2 & $4 \%$ \\
\hline Só video c/som & 1 & $0 \%$ & 0 & $0 \%$ & 0 & $0 \%$ & 0 & $0 \%$ & 1 & $0 \%$ & 0 & $0 \%$ & 0 & $0 \%$ \\
\hline Texto + foto & 103 & $11 \%$ & 4 & $3 \%$ & 1 & $1 \%$ & 19 & $11 \%$ & 72 & $22 \%$ & 5 & $4 \%$ & 2 & $4 \%$ \\
\hline Texto + Álbum & 4 & $0 \%$ & 0 & $0 \%$ & 1 & $1 \%$ & 0 & $0 \%$ & 2 & $1 \%$ & 0 & $0 \%$ & 1 & $2 \%$ \\
\hline Texto + Video s/som & 17 & $2 \%$ & 3 & $2 \%$ & 1 & $1 \%$ & 0 & $0 \%$ & 6 & $2 \%$ & 7 & $6 \%$ & 0 & $0 \%$ \\
\hline Texto + Video c/som & 40 & $4 \%$ & 12 & $8 \%$ & 6 & $6 \%$ & 5 & $3 \%$ & 6 & $2 \%$ & 9 & $8 \%$ & 2 & $4 \%$ \\
\hline Texto + foto + link & 359 & $40 \%$ & 55 & $37 \%$ & 14 & $14 \%$ & 106 & $62 \%$ & 116 & $36 \%$ & 42 & $36 \%$ & 26 & $57 \%$ \\
\hline Texto + Álbum + link & 33 & $4 \%$ & 0 & $0 \%$ & 2 & $2 \%$ & 5 & $3 \%$ & 12 & $4 \%$ & 6 & $5 \%$ & 8 & $17 \%$ \\
\hline Texto + Video s/som + link & 100 & $11 \%$ & 8 & $5 \%$ & 19 & $20 \%$ & 9 & $5 \%$ & 47 & $14 \%$ & 15 & $13 \%$ & 2 & $4 \%$ \\
\hline Texto + Video c/som + link & 200 & $22 \%$ & 61 & $41 \%$ & 46 & $47 \%$ & 23 & $14 \%$ & 33 & $10 \%$ & 34 & $29 \%$ & 3 & $7 \%$ \\
\hline Total Posts & 906 & $100 \%$ & 149 & $100 \%$ & 97 & $100 \%$ & 170 & $100 \%$ & 326 & $100 \%$ & 118 & $100 \%$ & 46 & $100 \%$ \\
\hline
\end{tabular}

Tabela 19 - Posts com elementos de interatividade / vivacidade

Em relação aos tipos de links utilizados pode-se perceber pela tabela xxx que em termos de links com exceção do Bradesco que utilizou esse recurso em 39\% (38) dos seus posts, os demais bancos usam muito esse recurso em seus posts. Já a Hashtag é usada bastante por Itaú (65\%), Bradesco (75\%) e BB (58\%). Assim como o uso de GIFs para atingir um público jovem, as hashtags também podem ter esse efeito. Por fim, o botão é o recurso menos utilizado pelas marcas com apenas Citibank utilizando em um nível maior (24\%). Dos 11 posts com esse recurso do Citibank, 4 eram para "curtir uma página" de outra marca e 6 eram do tipo "saiba mais" para acessar o site do banco da marca. 


\begin{tabular}{|c|c|c|c|c|c|c|c|c|c|c|c|c|c|c|}
\hline \multirow[b]{2}{*}{ Tipo de Elemento } & \multicolumn{2}{|c|}{ Geral } & \multicolumn{2}{|c|}{ Itaú } & \multicolumn{2}{|c|}{ Bradesco } & \multicolumn{2}{|c|}{ Banco do Brasil } & \multicolumn{2}{|c|}{ CEF } & \multicolumn{2}{|c|}{ Santander } & \multicolumn{2}{|c|}{ Citibank } \\
\hline & Possui & Percent. & Possui & Percent. & Possui & Percent. & Possui & Percent. & Possui & Percent. & Possui & Percent. & Possui & \begin{tabular}{|l} 
Percent. \\
\end{tabular} \\
\hline Hyperlinks & 542 & $60 \%$ & 103 & $69 \%$ & 38 & $39 \%$ & 97 & $57 \%$ & 186 & $57 \%$ & 79 & $67 \%$ & 39 & $85 \%$ \\
\hline Hashtags & 396 & $44 \%$ & 97 & $65 \%$ & 73 & $75 \%$ & 98 & $58 \%$ & 87 & $27 \%$ & 34 & $29 \%$ & 7 & $15 \%$ \\
\hline Botões & 30 & $3 \%$ & 7 & $5 \%$ & 0 & $0 \%$ & 7 & $4 \%$ & 1 & $0 \%$ & 4 & $3 \%$ & 11 & $24 \%$ \\
\hline Nada & 214 & $24 \%$ & 25 & $17 \%$ & 16 & $16 \%$ & 27 & $16 \%$ & 118 & $36 \%$ & 21 & $18 \%$ & 7 & $15 \%$ \\
\hline Total Posts & 906 & $100 \%$ & 149 & $100 \%$ & 97 & $100 \%$ & 170 & $100 \%$ & 326 & $100 \%$ & 118 & $100 \%$ & 46 & $100 \%$ \\
\hline
\end{tabular}

Tabela 20 - tipos de links por banco

Abaixo exemplos de posts com diferentes tipos de elementos de interatividade e vivacidade.

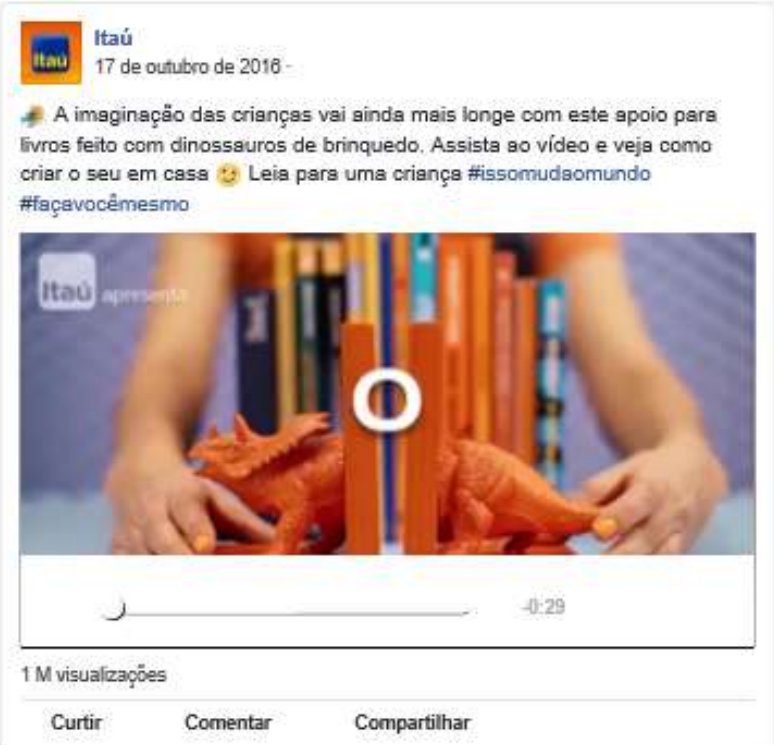

Figura 21 - Post de vídeo do Itaú com texto e Hashtag 
Bradesco

17 de agosto de 2016 .

Em busca do clique perfeito! I * Pause o gif e tente registrar o momento exato da pirueta da stleta. Depois, posta seu resultado aqui nos comentérios. Valendo! lo/ \#agorséBRA

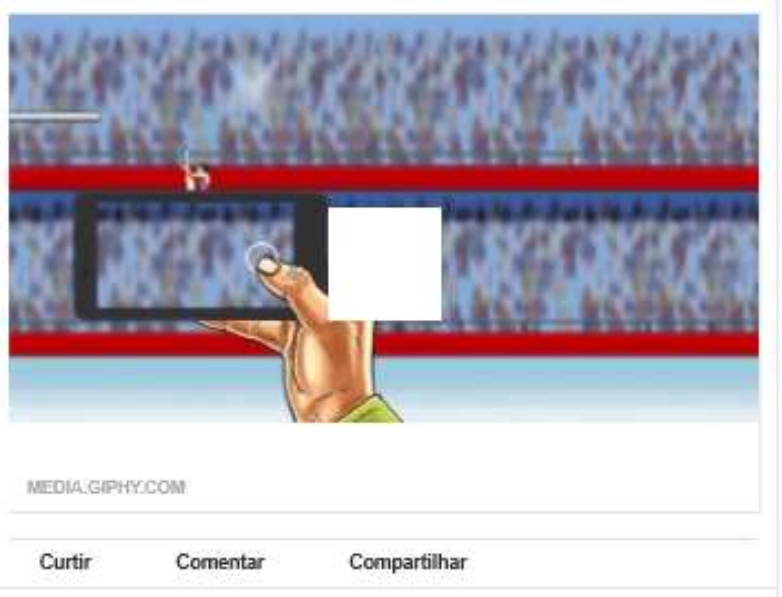

Figura 22 - post de vídeo sem som do Bradesco com texto e Hashtag

Banco do Brasil

2 de seternbro de 2016

Clientes e funcionários estão mobilizados para ajudar crianças e

adolescentes, que precisam de tratamento para vencer o câncer.

Você pode ajudar com doacões em Reais, pontos do programa Ponto pra

Você. Ponto pra sua Empresa e Dotz.

Você também pode ser voluntário ou, simplesmente, contribuir divulgando

informacôes para estimular a busca do diagnóstico precoce.

Para dar uma força, acesse www bb.com brfinfanciaevida.

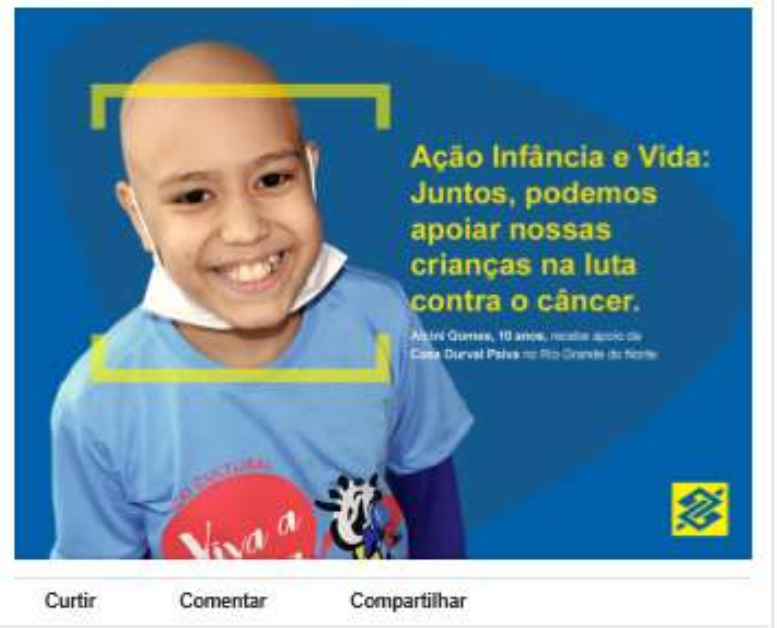

Figura 23 - post de foto do BB com texto e Hyperlink 
Citi Brasil

28 de novembro de 2016

\#TempoéTudo. Aproveite o seu.

Tempo não é o

relógio no pulso.

É o que você

faz das suas horas.

Tempo não é a

folha do calendá

É cuidar da

sua biografia.
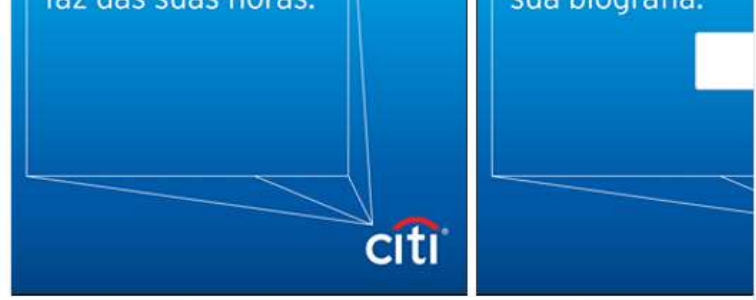

\#tempoétudo

CITIBANK.COM.BR

Saiba mais

Curtir Comentar Compartilhar

Figura 24 - post de Álbum do Citibank com texto e Hashtag

Quando analisado a quantidade de tipos de links dentro de um post, percebe-se que Itaú se destaca por utilizar dois elementos de interatividade (hyperlinks e hashtags) em $56 \%$ dos seus posts. Os demais bancos usam em mais de $50 \%$ dos seus posts um elemento. Por outro lado, a CEF se destaca por não usar nenhum desses elementos (hyperlink, hashtag ou botão) em $36 \%$ dos seus posts.

\begin{tabular}{|c|c|c|c|c|c|c|c|c|c|c|c|c|c|c|}
\hline & \multicolumn{2}{|c|}{ Geral } & \multicolumn{2}{|c|}{ Itaú } & \multicolumn{2}{|c|}{ Bradesco } & \multicolumn{2}{|c|}{ Banco do Brasil } & \multicolumn{2}{|c|}{ CEF } & \multicolumn{2}{|c|}{ Santander } & \multicolumn{2}{|c|}{ Citibank } \\
\hline Tipo de Elemento & Possui & Percent. & Possui & Percent. & Possui & Percent. & Possui & Percent. & Possui & Percent. & Possui & Percent. & Possui & Percent. \\
\hline 1 Elemento & 426 & $47 \%$ & 41 & $28 \%$ & 51 & $53 \%$ & 89 & $52 \%$ & 142 & $44 \%$ & 77 & $65 \%$ & 26 & $57 \%$ \\
\hline 2 Elementos & 256 & $28 \%$ & 83 & $56 \%$ & 30 & $31 \%$ & 49 & $29 \%$ & 66 & $20 \%$ & 20 & $17 \%$ & 8 & $17 \%$ \\
\hline 3 Elementos & 10 & $1 \%$ & 0 & $0 \%$ & 0 & $0 \%$ & 5 & $3 \%$ & 0 & $0 \%$ & 0 & $0 \%$ & 5 & $11 \%$ \\
\hline Nenhum & 214 & $24 \%$ & 25 & $17 \%$ & 16 & $16 \%$ & 27 & $16 \%$ & 118 & $36 \%$ & 21 & $18 \%$ & 7 & $15 \%$ \\
\hline Total Posts & 906 & $100 \%$ & 149 & $100 \%$ & 97 & $100 \%$ & 170 & $100 \%$ & 326 & $100 \%$ & 118 & $100 \%$ & 46 & $100 \%$ \\
\hline
\end{tabular}

Tabela 21 - quantidade de tipos de links por post e marca

\subsection{Alocação dos posts no tempo}

O período do dia mais utilizado pelos bancos foi a tarde com $38 \%$ seguido do período da noite com 31\% e manhã com 30\%. Entre as marcas percebe-se algumas diferenças nas suas estratégias. Itaú (50\%), Santander (55\%) e Citibank (46\%) utilizam mais o período da tarde para fazer as suas postagens. 
Já Bradesco prefere concentram as suas postagens no período da manhã (69\%). Por fim, a CEF (42\%) e BB (41\%) postaram mais no período noturno. Nota-se, portanto, que em relação ao melhor horário para fazer as postagens, não existe uma estratégia igual para as marcas.

\begin{tabular}{|c|c|c|c|c|c|c|c|c|c|c|c|c|c|c|}
\hline \multirow[b]{2}{*}{ Período do dia } & \multicolumn{2}{|c|}{ Geral } & \multicolumn{2}{|c|}{ Itaú } & \multicolumn{2}{|c|}{ Bradesco } & \multicolumn{2}{|c|}{ Banco do Brasil } & \multicolumn{2}{|c|}{ CEF } & \multicolumn{2}{|c|}{ Santander } & \multicolumn{2}{|c|}{ Citibank } \\
\hline & Qtde & Percent. & Qtde & Percent. & Qtde & Percent. & Qtde & Percent. & Qtde & Percent. & Qtde & Percent. & Qtde & Percent. \\
\hline Manhã & 274 & $30 \%$ & 43 & $29 \%$ & 67 & $69 \%$ & 56 & $33 \%$ & 64 & $20 \%$ & 26 & $22 \%$ & 18 & $39 \%$ \\
\hline Tarde & 348 & $38 \%$ & 74 & $50 \%$ & 20 & $21 \%$ & 43 & $25 \%$ & 125 & $38 \%$ & 65 & $55 \%$ & 21 & $46 \%$ \\
\hline \begin{tabular}{|l|} 
Noite \\
\end{tabular} & 280 & $31 \%$ & 30 & $20 \%$ & 10 & $10 \%$ & 70 & $41 \%$ & 137 & $42 \%$ & 26 & $22 \%$ & 7 & $15 \%$ \\
\hline Madrugada & 4 & $0 \%$ & 2 & $1 \%$ & 0 & $0 \%$ & 1 & $1 \%$ & 0 & $0 \%$ & 1 & $1 \%$ & 0 & $0 \%$ \\
\hline Total Posts & 906 & $100 \%$ & 149 & $100 \%$ & 97 & $100 \%$ & 170 & $100 \%$ & 326 & $100 \%$ & 118 & $100 \%$ & 46 & $100 \%$ \\
\hline
\end{tabular}

Tabela 22 - Frequência de posts por período

Sexta-feira concentra $23 \%$ dos posts e é o dia da semana mais utilizado pelas marcas para postar. Das seis marcas, cinco utilizam mais a sexta-feira para postar. Quinta-feira é o segundo dia da semana mais utilizado pelas marcas. É o segundo dia de mais postagem para três marcas. Em seguida vem a quartafeira. Já Sábado e Domingo são os dias menos utilizados pelas marcas para postar. Bradesco ainda tem uma quantidade significativa de posts no domingo em função dos encerramentos dos jogos olímpicos e paraolímpicos do Rio de Janeiro. Citibank tem uma grande concentração de post na sexta-feira (35\%) muito provavelmente em função dos conteúdos dos posts que são referentes ao uso do cartão para aquisição de ingressos para shows e outros descontos e benefícios utilizando o cartão. Pode-se dizer que as marcas concentram seus posts entre a quarta-feira e a sexta-feira e utiliza menos os finais de semana.

\begin{tabular}{|c|c|c|c|c|c|c|c|c|c|c|c|c|c|c|}
\hline \multirow[b]{2}{*}{ Dia da semana } & \multicolumn{2}{|c|}{ Geral } & \multicolumn{2}{|c|}{ Itaú } & \multicolumn{2}{|c|}{ Bradesco } & \multicolumn{2}{|c|}{ Banco do Brasil } & \multicolumn{2}{|c|}{ CEF } & \multicolumn{2}{|c|}{ Santander } & \multicolumn{2}{|c|}{ Citibank } \\
\hline & Qtde & Percent. & Qtde & \begin{tabular}{|l|} 
Percent. \\
\end{tabular} & Qtde & Percent. & Qtde & Percent. & Qtde & Percent. & Qtde & Percent. & Qtde & Percent \\
\hline Segunda & 135 & $15 \%$ & 25 & $17 \%$ & 8 & $8 \%$ & 22 & $13 \%$ & 48 & $15 \%$ & 25 & $21 \%$ & 8 & $17 \%$ \\
\hline Terça & 138 & $15 \%$ & 24 & $16 \%$ & 15 & $15 \%$ & 25 & $15 \%$ & 54 & $17 \%$ & 15 & $13 \%$ & 4 & $9 \%$ \\
\hline Quarta & 151 & $17 \%$ & 21 & $14 \%$ & 14 & $14 \%$ & 21 & $12 \%$ & 73 & $22 \%$ & 17 & $14 \%$ & 5 & $11 \%$ \\
\hline Quinta & 156 & $17 \%$ & 33 & $22 \%$ & 19 & $20 \%$ & 27 & $16 \%$ & 53 & $16 \%$ & 17 & $14 \%$ & 7 & $15 \%$ \\
\hline Sexta & 205 & $23 \%$ & 36 & $24 \%$ & 23 & $24 \%$ & 36 & $21 \%$ & 74 & $23 \%$ & 20 & $17 \%$ & 16 & $35 \%$ \\
\hline Sábado & 62 & $7 \%$ & 7 & $5 \%$ & 6 & $6 \%$ & 22 & $13 \%$ & 11 & $3 \%$ & 14 & $12 \%$ & 2 & $4 \%$ \\
\hline Domingo & 59 & $7 \%$ & 3 & $2 \%$ & 12 & $12 \%$ & 17 & $10 \%$ & 13 & $4 \%$ & 10 & $8 \%$ & 4 & $9 \%$ \\
\hline Total Posts & 906 & $100 \%$ & 149 & $100 \%$ & 97 & $100 \%$ & 170 & $100 \%$ & 326 & $100 \%$ & 118 & $100 \%$ & 46 & $100 \%$ \\
\hline
\end{tabular}

Tabela 23 - Frequência de posts por dia da semana 
(1) Bradesco

21 de agosto de 2016

Os Jogos \#Rio2016 foram incriveis. Năo tinhs como ser diferente, sfinal, os

protagonistas dessa festa foram os brasileiros. Estamos falando de todos

aqueles que torceram, que se emocionaram, que se divertiram e também

que trabslharam duro dia e noite. Acompanhe foto a foto essa experiência

inesquecivel, através dos olhos de quem fez tudo isso scontecer. lo

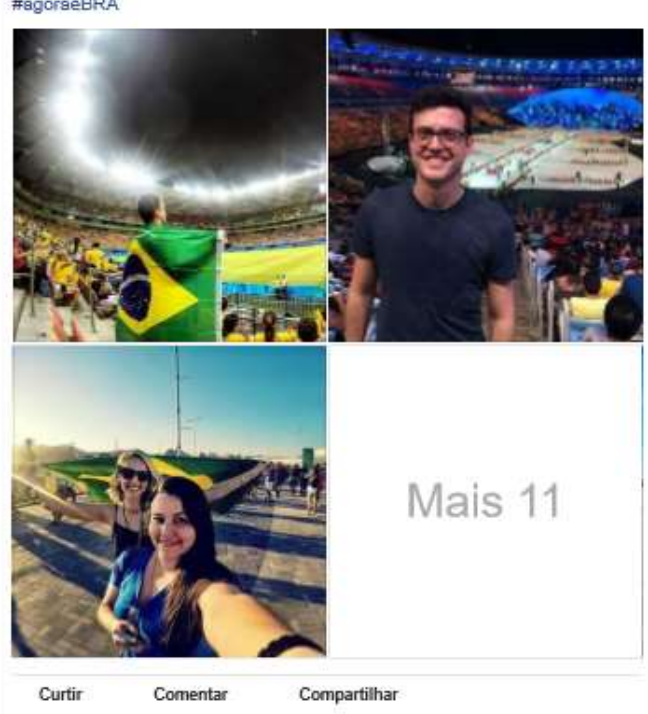

Figura 25 - post do Bradesco no domingo (Dia de encerramento das Olimpíadas)

Os meses compreendidos entre os meses de julho a setembro e o mês de dezembro foram os meses mais ativos em postagens. Bradesco teve uma maior concentração de posts entre agosto e setembro devido as Olímpiadas e Paraolimpíadas realizadas no Rio de Janeiro nesse período. Por outro lado, após esses eventos ficou praticamente sem postar nos meses de outubro e novembro com apenas 3 posts em cada um desses meses.

\begin{tabular}{|c|c|c|c|c|c|c|c|c|c|c|c|c|c|c|}
\hline & \multicolumn{2}{|c|}{ Geral } & \multicolumn{2}{|c|}{ Itaú } & \multicolumn{2}{|c|}{ Bradesco } & \multicolumn{2}{|c|}{ Banco do Brasil } & \multicolumn{2}{|c|}{ CEF } & \multicolumn{2}{|c|}{ Santander } & \multicolumn{2}{|c|}{ Citibank } \\
\hline Meses & Qtde & Percent. & Qtde & Percent. & Qtde & Percent. & Qtde & Percent. & Qtde & Percent. & Qtde & Percent. & Qtde & Percent. \\
\hline Julho & 169 & $19 \%$ & 26 & $18 \%$ & 9 & $9 \%$ & 32 & $19 \%$ & 76 & $24 \%$ & 18 & $15 \%$ & 8 & $17 \%$ \\
\hline Agosto & 179 & $20 \%$ & 32 & $22 \%$ & 38 & $40 \%$ & 27 & $16 \%$ & 64 & $20 \%$ & 15 & $13 \%$ & 3 & $7 \%$ \\
\hline Setembro & 164 & $18 \%$ & 29 & $20 \%$ & 27 & $28 \%$ & 47 & $28 \%$ & 33 & $10 \%$ & 22 & $19 \%$ & 6 & $13 \%$ \\
\hline Outubro & 117 & $13 \%$ & 25 & $17 \%$ & 3 & $3 \%$ & 25 & $15 \%$ & 38 & $12 \%$ & 13 & $11 \%$ & 13 & $28 \%$ \\
\hline Novembro & 111 & $12 \%$ & 19 & $13 \%$ & 3 & $3 \%$ & 12 & $7 \%$ & 41 & $13 \%$ & 28 & $24 \%$ & 8 & $17 \%$ \\
\hline Dezembro & 159 & $18 \%$ & 16 & $11 \%$ & 16 & $17 \%$ & 27 & $16 \%$ & 71 & $22 \%$ & 21 & $18 \%$ & 8 & $17 \%$ \\
\hline Total Posts & 899 & $100 \%$ & 147 & $100 \%$ & 96 & $100 \%$ & 170 & $100 \%$ & 323 & $100 \%$ & 117 & $100 \%$ & 46 & $100 \%$ \\
\hline
\end{tabular}

Tabela 24 - Frequência de posts por mês

O gráfico da figura 26 mostra que enquanto Itaú, CEF, Santander e Banco do Brasil levam até 2,5 dias para postar em média por mês. Bradesco e Citibank 
tem grandes oscilações na média de dias que levam para postar por mês. CEF chegou a postar nos meses de julho e dezembro uma média de mais de 2 posts por dia. Um exemplo de muitos posts em um dia ocorreu em 21/07 quando a CEF postou 6 vezes entre 11:00 e 20:00 sobre assuntos variados (ver quadro 5).

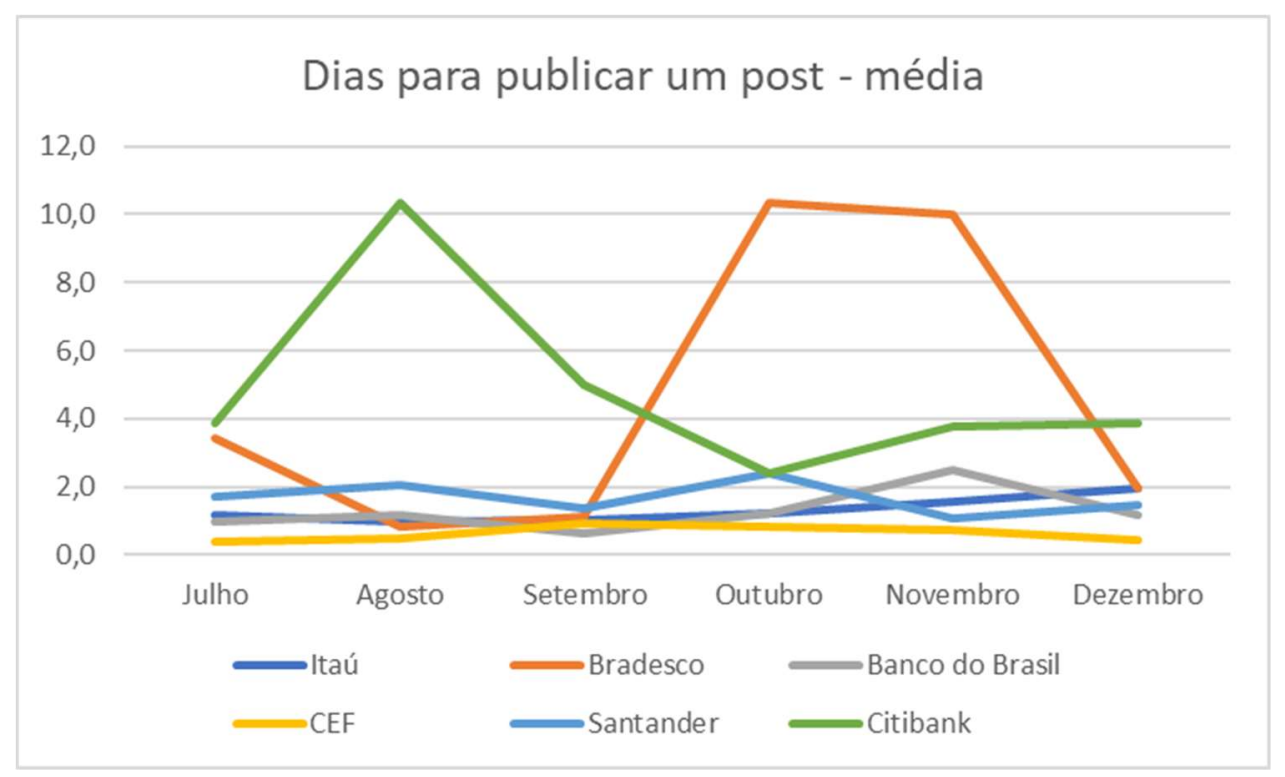

Figura 26 - Média de dias para publicar um post por mês e marca

\begin{tabular}{|r|r|l|l|}
\hline Dia/mês & \multicolumn{1}{|c|}{ Horário } & Período & Assunto \\
\hline $21 /$ jul & $11: 00$ & Manhã & Renegociação de dívidas \\
\hline $21 /$ jul & $16: 10$ & Tarde & Projetos Culturais \\
\hline $21 /$ jul & $17: 07$ & Tarde & Atualização da foto da capa \\
\hline $21 /$ jul & $18: 00$ & Noite & Segurança \\
\hline $21 /$ jul & $19: 00$ & Noite & Renegociação de dívidas \\
\hline $21 /$ jul & $20: 00$ & Noite & Abono Salarial e PIS \\
\hline
\end{tabular}

Quadro 5 - Posts da CEF em um único dia

Resumindo a atuação das marcas no quadro 6 , pode-se notar que em termos de tipo de conteúdo as marcas estão agrupadas em Entretenimento, mais voltada em construção de marca e outro grupo mais voltado para o informativo, na divulgação de informações de produtos, serviços e sobre a empresa, ou seja um foco mais orientado à negócios. Santander e Citi mais voltado ainda à negócios 
com conteúdo também de remuneração como descontos, benefícios para uso dos seus produtos e serviços.

Em termos de vivacidade e interatividade, nota-se que todos as marcas usam os elementos de interatividade e vivacidade de maneira moderada e alta - uso de fotos e vídeos e bastante uso de links simultaneamente no post. Dois grupos parecem emergir. Itaú e Bradesco com alto uso de elementos de interatividade e vivacidade (maior uso de vídeos com links). E o segundo grupo com os demais bancos com uso moderado (variando de moderado baixo - CEF usa os recursos de foto e não é tão frequente o uso de links como os outros bancos, moderado - BB e Citibank usam muita foto e/ou Álbum com link e, moderado alto Santander usa foto (36\%) e vídeo (29\%) de maneira mais equilibrada com links).

Em relação ao momento de colocação do post, em termos do período do dia, as marcas têm preferências distintas. Bradesco prefere o período da manhã. Itaú, Santander e Citibank preferem o período da tarde. E BB e CEF preferem o período noturno. Quanto ao dia da semana a sexta-feira é o dia mais intenso de postagens para as marcas, com exceção do Santander que preferiu a Segundafeira (mas o segundo dia mais importante foi a sexta-feira). De maneira geral os dias mais postados foram de quarta-feira a sexta-feira e os dias menos postados os sábados e domingos. Quanto aos meses, Bradesco muito intenso em agosto, Itaú um pouco mais intenso em agosto que nos outros meses, BB com mais postagens em setembro, Citibank em outubro e Santander em novembro. Nenhum mês onde pudesse se notar uma preferência do setor financeiro. Por fim, analisando a frequência com que as marcas postavam, é nítida a diferença de algumas marcas. Dois grupos emergem dessa análise, um grupo com marcas que possuem uma consistência na postagem das suas mensagens levando entre 0,4 a 2,5 dias para postar (Itaú, BB, CEF e Santander) - mantendo assim uma interação maior com seus fãs, e outro grupo com baixa consistência na frequência das postagens, levando de 0,8 dia em média em um determinado mês a 10,3 dias em outro para postar uma mensagem (Bradesco e Citibank). Notase nesse segundo grupo uma atuação mais pontual, mais voltada para aproveitar uma oportunidade momentânea. Dessa forma pode-se descrever as marcas da seguinte forma: 
Itaú, foco em entretenimento, uso de elementos de alta vivacidade/interatividade e consistente na frequência com que posta as suas mensagens. É uma marca que foca na construção de marca, com uso de recursos mais interativos/vívidos e que quer manter uma comunicação presente com seus fãs. Uma frase para representar essa marca seria: "Quero construir marca de maneira destacada e constante".

Bradesco, foco em entretenimento, uso de elementos de alta vivacidade/interatividade e baixa consistência na frequência com que posta as suas mensagens. É uma marca que parece focar na construção de marca, com uso de recursos mais interativos/vívidos e que busca momentos oportunos para se comunicar. A frase para representar essa marca seria: "Quero construir marca, de maneira destacada e quando me convier".

\begin{tabular}{|c|c|c|c|c|c|c|}
\hline Marca & Tipo de conteúdo & Vivacidade e Interatividade & $\begin{array}{c}\text { Período } \\
\text { mais } \\
\text { utilizado }\end{array}$ & \begin{tabular}{|c|} 
Dia da \\
semana \\
mais \\
utilizado
\end{tabular} & $\begin{array}{c}\text { Mês } \\
\text { mais } \\
\text { postado }\end{array}$ & $\begin{array}{c}\text { Consistência de } \\
\text { postagem } \\
\text { (frequência - média } \\
\text { mensal) }\end{array}$ \\
\hline Itaú & Entretenimento & $\begin{array}{l}\text { Uso maior de video( } 46 \%) \text { do que foto } \\
(37 \%) \text { com links }\end{array}$ & Tarde & Sexta & Agosto & entre 1,0 e 1,9 dias \\
\hline Bradesco & Entretenimento & $\begin{array}{l}\text { Uso maior de video com (47\%) e sem } \\
\text { som }(20 \%) \text { com links }\end{array}$ & Manhã & Sexta & Agosto & entre 0,8 e 10,3 dias \\
\hline BB & Informativo & $\begin{array}{l}\text { Uso de muita foto(62\%) e menos } \\
\text { video c/som (14\%) com links }\end{array}$ & Noite & Sexta & Setembro & entre 0,6 e 2,5 dias \\
\hline CEF & Informativo & $\begin{array}{l}\text { Uso de foto com (36\%) e sem (22\%) } \\
\text { links }\end{array}$ & Noite & Sexta & Julho & entre 0,4 e 0,9 dias \\
\hline Santander & Informativo c/ mais Remuneração & $\begin{array}{l}\text { Uso maior de foto (36\%) que video } \\
(29 \%) \text { com links }\end{array}$ & Tarde & Segunda & Novembrd & dentre 1,1 e 2,4 dias \\
\hline Citibank & Informativo c/ mais Remuneração & $\begin{array}{l}\text { Uso maior de foto (57\%) e álbum } \\
(17 \%) \text { com links }\end{array}$ & Tarde & Sexta & Outubro & entre 2,4 e 10,3 dias \\
\hline
\end{tabular}

Quadro 6 - síntese das estratégias das marcas

Banco do Brasil, foco em conteúdo informativo, com uso de elementos de moderada interatividade/vivacidade e consistente na frequência com que posta as suas mensagens. É uma marca orientada a negócios, com uso de recursos moderados de interatividade/vivacidade e que quer manter uma comunicação constante com seus fãs. Para o BB a frase seria: "Quero falar de negócios de maneira moderada e constante".

Caixa Econômica Federal, foco em conteúdo informativo, com uso de elementos de moderada interatividade/vivacidade e consistente na frequência com que posta as suas mensagens. É uma marca orientada a negócios, com uso de 
recursos de moderada interatividade/vivacidade e que quer manter uma comunicação constante e mais intensa com seus fãs. No caso da CEF a frase poderia ser: "Quero falar de negócios de maneira moderada, constante e mais vezes".

Santander, foco em conteúdo informativo com uso um pouco maior de conteúdo de remuneração que as marcas anteriores, com uso de elementos de moderada interatividade/vivacidade e consistente na frequência com que posta as suas mensagens. É uma marca orientada a negócios que usa a página não somente para informar, mas também para vender seus produtos e serviços, com uso de recursos de moderada a alta interatividade/vivacidade e que quer manter uma comunicação constante com seus fãs. Já no caso do Santander a frase seria: "Quero falar e fazer negócios de maneira moderada e constante".

Citibank, foco em conteúdo informativo com uso um pouco maior de conteúdo de remuneração assim como o Santander, com uso de elementos de moderada interatividade/vivacidade e baixa consistência na frequência com que posta as suas mensagens. É uma marca orientada a negócios que usa a página não somente para informar, mas também para vender seus produtos e serviços, com uso de recursos de moderada a alta interatividade/vivacidade e que quer manter uma comunicação constante com seus fãs. Por fim, o Citibank ficaria com uma frase: "Quero falar e fazer negócios de maneira moderada em determinados momentos".

A figura 27 é uma representação ilustrativa das marcas com base na interatividade / vivacidade $\mathrm{x}$ Consistência na frequência de postagens $\mathrm{e}$ interatividade/vivacidade $\mathrm{x}$ tipos de conteúdo 


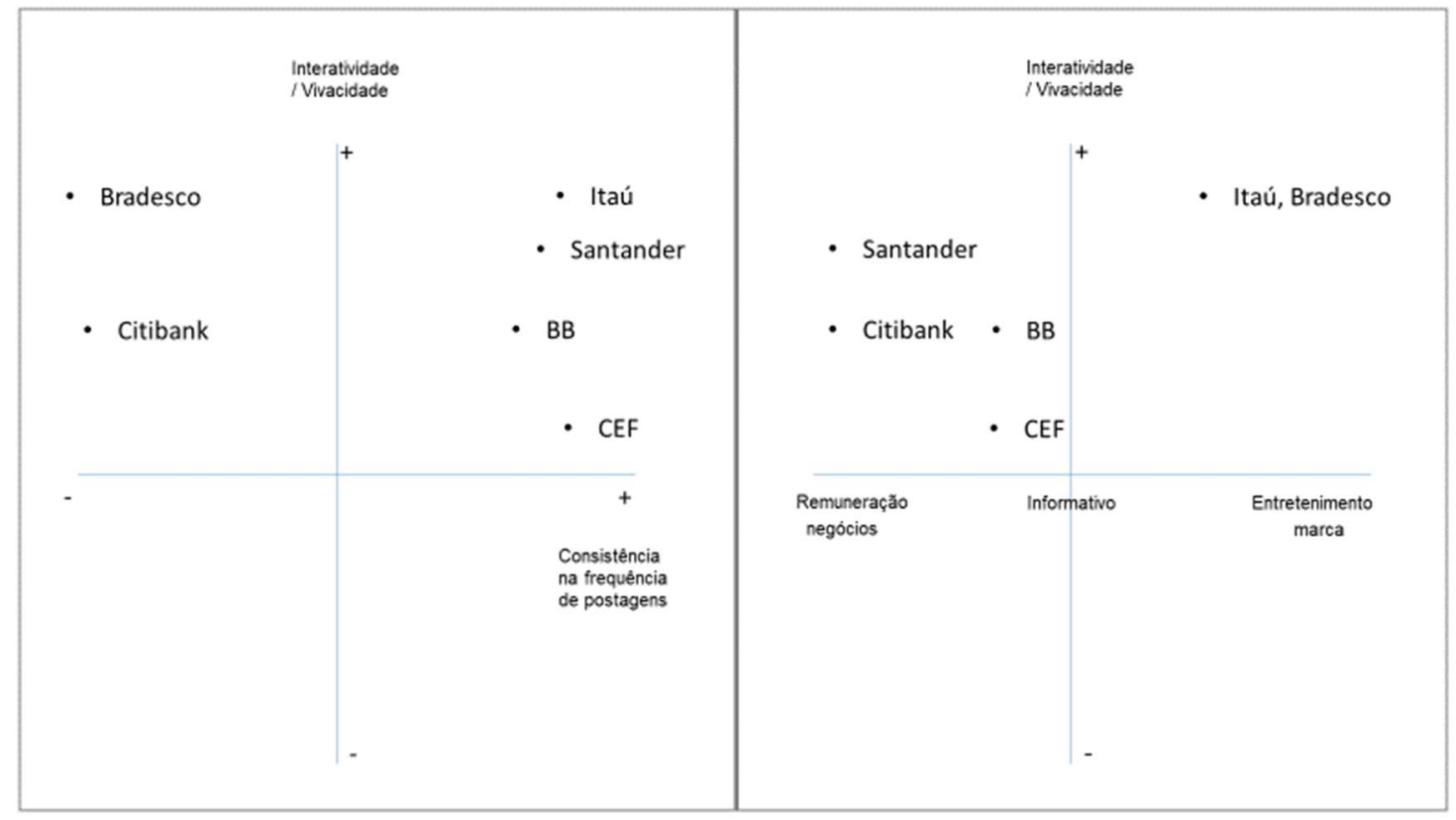

Figura 27 - Representação ilustrativa das marcas com base na interatividade/vivacidade $x$ Consistência na frequência de postagens e interatividade/vivacidade $x$ tipos de conteúdo 


\section{CONSIDERAÇÕES FINAIS}

As considerações finais desse estudo estão divididas em três partes: 1) Conclusões, apresentando as respostas para a pergunta dessa pesquisa; 2) Implicações gerenciais e 3) Limitações e recomendações para estudos futuros.

\subsection{Conclusões}

O objetivo deste estudo era entender quais eram as estratégias de comunicação das marcas de bancos no mercado brasileiro dentro das mídias sociais, mais especificamente no Facebook. Dentro das estratégias de comunicação este estudo, através da revisão da literatura, buscou analisa-las sobre 3 aspectos: conteúdos motivadores com o suporte da teoria de usos e gratificações, elementos de atração e interação da comunicação através dos conceitos de vivacidade e interatividade, conceitos que se destacam no universo das mídias sociais e análise do momento, frequência, consistência com que as marcas divulgam as suas comunicações.

As mídias sociais mudaram a forma como se faz comunicação entre marcas e consumidores. Antes a mídia tradicional tinha uma comunicação unidirecional, com pouca interatividade, assíncrona e com menos recursos. Já na atualidade com as mídias sociais e com a profusão de redes sociais, blogs, fóruns etc. o consumidor passou a exercer uma comunicação bidirecional, um diálogo com as marcas e com outras pessoas em um patamar de interação nunca visto até então. As pessoas podem ler, ver um conteúdo assim como podem também criar conteúdo e disponibilizar para outras pessoas e até para as marcas. A comunicação pode ocorrer tanto em tempo real como em uma conversa em um chat como de maneira assíncrona como ler um post na sua página depois de horas da publicação. Uma consequência disso é a explosão de conteúdo disponível nas mídias sociais. São muitas pessoas e marcas nas mídias sociais gerando conteúdo. Só no Facebook são quase dois bilhões de usuários cadastrados. Assim, a quantidade de posts que poderiam estar visíveis a disposição de um usuário comum do Facebook seria em torno de 1.500 posts a cada vez que ele se conectasse na sua conta (Boland, 2014). Porém, o Facebook tem um algoritmo que filtra as mensagens e disponibiliza apenas cerca 
de 300 mensagens. Com isso o alcance orgânico das marcas, sem a necessidade de pagar, caiu para em torno de $2 \%$ da base de usuários das grandes marcas (Delo, 2014). Portanto, torna-se ainda mais relevante adotar uma estratégia de comunicação. Esta pode ser definida através do tipo de conteúdo para a comunicação, do grau de interatividade e vivacidade da comunicação e em que momento, com que frequência a marca se comunica. Foi visto que a teoria de usos e gratificações é muito utilizado para estudos de comunicação nas mídias sociais e informativo, entretenimento e remuneração são os tipos de conteúdo mais presentes nos estudos (Celebi, 2015; Cvijikj e Michahelles, 2013 Muntinga et al., 2011). Em relação a interatividade/ vivacidade são conceitos que ganharam muita força e são muito utilizados na comunicação no universo das mídias sociais. Vivacidade tem a capacidade de atrair a atenção do usuário. Elementos mais vívidos como as imagens despertam mais a atenção que somente texto, Vídeos mais que fotos. Interatividade tem a função de gerar mais interação, de estreitar o relacionamento, de estabelecer um diálogo com a marca. Dessa forma, vídeos são mais interativos que foto pois demandam mais interação do usuário do que uma foto. Um link gera mais interação.

Em relação ao método como o estudo buscava o entendimento de quais eram as estratégias de comunicação dos bancos no Facebook, o melhor tipo de pesquisa era a qualitativa. Os dados foram coletados através das páginas oficiais das marcas no Facebook todos os dias durante seis meses. A princípio com base em estudos prévios foi definido um período de três meses. Mas durante o período de coleta com base em eventos de grande magnitude (Olimpíadas/Paraolimpíadas) que podiam gerar um viés na análise, optou-se por estender a coleta por mais tempo. Um guia de codificação foi criado com base nas categorias obtidas na revisão da literatura e posteriormente com a coleta dos dados o guia passou por algumas adequações. As análises foram realizadas após o cálculo das frequências simples das categorias levantadas.

Os resultados demonstraram que as estratégias de comunicação não são iguais entre as marcas analisadas. Com base nos tipos de conteúdo percebe-se que existem duas estratégias de comunicação. Um grupo busca a construção de marca entregando mais conteúdo de entretenimento, mais centrado no estabelecimento de um de relacionamento, de entreter o usuário. $O$ segundo 
bloco são marcas que usam a comunicação para divulgar os seus negócios, falando de produtos, serviços ou da empresa. Neste grupo inclusive pode-se dizer que as duas marcas internacionais têm uma orientação mais forte ainda para negócios pois na análise, percebeu-se que elas postam mais conteúdo de remuneração que as demais marcas, mais voltados para a venda de produtos e serviços. Em termos de interatividade, vivacidade as marcas usam bastante destes recursos com a utilização praticamente de $100 \%$ de algum tipo de imagem em seus posts. O que muda é intensidade no uso desses elementos. De novo Itaú e Bradesco são os que mais usam em intensidade de vivacidade, interatividade - usando mais vídeo que as demais marcas. Os outros bancos usam de maneira mais moderada estes elementos. Por fim, a questão do tempo permite avaliar principalmente a questão da consistência da postagem das marcas. Aqui existem diferenças entre uso mais contínuo e uso esporádico. No grupo dos esporádicos apareceram Bradesco e Citibank o que indica uma atuação para obter resultados momentâneos, com objetivos mais pontuais. Já no outro grupo composto de Itaú, CEF, BB e Santander as marcas atuaram de maneira mais contínua.

Por fim, este estudo contribuiu para gerar mais conhecimento tanto em termos do setor analisado, da comunicação na perspectiva das marcas quanto da região, todos pouco explorados nos estudos prévios.

\subsection{Implicações gerenciais}

No campo gerencial o tema é de suma importância dada a participação dos consumidores nas mídias sociais e a possibilidade de estabelecer um diálogo, criar ou intensificar o relacionamento e gerar negócios com as marcas. No caso do banco onde a percepção do setor tem uma imagem negativa, de lucros extorsivos, as mídias sociais servem para mitigar riscos de imagem, ao buscar a criação de uma imagem positiva para a marca. Para tanto, ter uma comunicação adequada em conteúdo, no momento e na frequência certa é essencial para que as marcas consigam serem vistas, estabeleçam um diálogo e criem vínculos com a marca. Este estudo aponta para os profissionais de marketing, sobretudo aqueles voltados para os meios digitais, a importância em 
escolher o melhor conteúdo para a sua marca, seja este conteúdo informativo, de entretenimento ou remuneração e, que o tipo depende muito da estratégia de cada empresa. Como visto, se não existe um consenso nem entre as marcas de bancos, de um único setor, muito mais difícil em outros setores. Em relação a elementos que tragam vivacidade - que despertem a atenção dos usuários e interatividade - que gerem o interesse em interagir é possível perceber o uso grande desses elementos pelas marcas dos bancos. Porém, é preciso saber o grau de interatividade e vivacidade que cada marca deve aplicar a seu público e o momento de fazer isso. Além disso, sabendo que o algoritmo do Facebook penaliza quem não utiliza imagens torna ainda mais relevante ter em conta o uso desse elemento nos posts das marcas. E o momento é uma questão-chave quando se fala em estratégia de comunicação, pois o momento correto para disponibilizar o conteúdo pode ser determinante para que o fã da marca possa ver o post. Por último, um aspecto fundamental é a frequência com que se disponibiliza o conteúdo. Se uma marca quer estabelecer um diálogo com os seus fãs deve fazer isso de maneira contínua, com diálogos frequentes e não pode manter conversas intensas em um determinado momento e ficar ausente por longos períodos em outros.

\subsection{Limitações e recomendações futuras}

A pesquisa de campo realizada trouxe informações relevantes quanto as estratégias de comunicação utilizada pelos bancos no Facebook o que tornou possível entender as estratégias empregadas no setor. Porém, é necessário ressaltar algumas limitações nesse estudo. Este é um estudo delimitado as marcas do setor financeiro no Brasil. Portanto, este estudo não é generalizável a outros setores da economia. No caso do método escolhido para análise de conteúdo ele foi subjetivo - dependia da interpretação de quem analisava o material. $O$ tempo analisado de 6 meses poderia ser maior para averiguar alguma sazonalidade no decorrer de um ano inteiro ou até dois anos pois, no período coletado, ocorreram dois eventos muito singulares, as Olimpíadas e as Paraolimpíadas no Rio de Janeiro. Dada a proporção desses eventos pode ser que tenha ocasionado um comportamento diferente das marcas quanto as suas estratégias de comunicação. 
Quanto as recomendações, seria interessante medir a reação dos fãs em relação as estratégias de comunicação das marcas através das quantidades de curtidas, compartilhamentos e comentários. Especificamente sobre os comentários, os bancos são bastante criticados pela população brasileira (Nepomuceno \& Porto, 2010). Uma sugestão seria analisar tanto a reação quanto a valência dos comentários para verificar se as páginas das marcas são "muros da lamentação" de usuários insatisfeitos com a marca.

Dentro da área do texto existem três estudos que podem ser feitos. O primeiro, para investigar se a proliferação de links, hashtags, botões e outras formas de interação podem ajudar ou atrapalhar a disposição do usuário em ler o post e se existem diferenças no nível de interatividade, vivacidade desses elementos. Como explanado por Ashley e Tuten (2015) a interatividade poderia ser "muito desgastante, aumentando a carga cognitiva de processar a mensagem de uma marca em um ambiente onde o consumidor está tentando proteger os recursos cognitivos". Um outro fator que pode impactar os links foi citado por Liu, Li, Ji, North, \& Yang (2017): "os usuários podem ignorar os hiperlinks da mesma forma que eles ignoram os banners de propaganda". O segundo, envolve o tamanho do texto. Um texto grande estimula, desestimula ou é indiferente para o usuário? Por fim, a presença de emoticons gera alguma reação no usuário? O tempo de duração dos vídeos impacta na reação dos usuários. Qual a duração de tempo que gera os melhores resultados para as marcas?

Outra sugestão para as marcas do setor financeiro é averiguar o tipo de público-alvo da comunicação. No setor financeiro existem diversos públicosalvo como, por exemplo, Pessoa Física, Pessoa Jurídica, Aposentados, Agronegócio, Universitários etc o que pode determinar a quantidade de fãs da página da marca que podem ter interesse no post.

Uma questão mais difícil de viabilizar, mas de grande importância é a investigação do impacto dos posts pagos. Como divulgado por Delo em 2014, marcas com mais de 500 mil fãs no Facebook viram o alcance orgânico cair para aproximadamente $2 \%$ de sua base. As marcas cientes dessa queda estão pagando mais para divulgar os seus posts? Qual o resultado alcançado com posts pagos? Qual o impacto que esta estratégia gera em outras variáveis? 
Pensando em outras mídias sociais qual a estratégia das marcas nas outras mídias? São iguais? Estão alinhadas em relação ao posicionamento da marca? Por fim, como última sugestão de estudo seria interessante replicar esta pesquisa em outros países para descobrir se existem similaridades ou diferenças nas estratégias de comunicação. 


\section{REFERÊNCIAS}

Ab Hamid, N. R., Razak, U. T. A., Akhir, R. M., \& Cheng, A. Y. (2009). Social media: An emerging dimension of marketing communication. Journal of Management and Marketing Research, 1-8.

Allsop, D. T., Bassett, B. R., \& Hoskins, J. A. (2007). Word-of-mouth research: principles and applications. Journal of advertising research, 47(4), 398411.

Arenas-Gaitan, J., Rondan-Cataluña, F. J., \& Ramírez-Correa, P. E. (2013). Social identity, electronic word-of-mouth and referrals in social network services. Kybernetes, 42(8), 1149-1165.

Ashley, C., \& Tuten, T. (2015). Creative strategies in social media marketing: An exploratory study of branded social content and consumer engagement. Psychology \& Marketing, 32(1), 15-27.

Bardin, L. (2009). Análise de Conteúdo Análise de Conteúdo: Edições 70/LDA.

Barreto, A. M. (2013). Do users look at banner ads on Facebook?. Journal of Research in Interactive Marketing, 7(2), 119-139.

Belch, G. E., \& Belch, M. E. (2014). Propaganda e Promoção-: Uma Perspectiva da Comunidação Integrada de Marketing: AMGH Editora.

Belk, R., Fischer, E., \& Kozinets, R. V. (2013). Qualitative consumer and marketing research: Sage.

Berger, J. (2014). Contágio: Por que as coisas pegam. São Paulo: Texto.

Berger, J., \& Milkman, K. L. (2012). What makes online content viral?. Journal of marketing research, 49(2), 192-205.

Bernoff, J., \& Li, C. (2008). Harnessing the power of the oh-so-social web. MIT Sloan management review, 49(3), 36.

Berry, L.L., Bolton, R.N., Bridges, C.H., Meyer, J., Parasuraman, A. and Seiders, K. (2010), "Opportunities for innovation in the delivery of interactive retail services", Journal of Interactive Marketing, Vol. 24 No. 2, pp. $155-167$.

Boland, B. (2014). Alcance orgânico no Facebook: suas dúvidas respondidas. Disponível em: https://www.facebook.com/business/news/BR-Alcanceorganico-no-Facebook-suas-duvidas-respondidas 
Bolton,R.N.,Parasuraman,A.,Hoefnagels,A.,Migchels,N.,Kabadayi,S., Gruber,T., Loureiro,Y.K. and Solnet, D. (2013), "Understanding Generation Y and their use of social media: a review and research agenda", Journal of Service Management, Vol. 24 No. 3, pp. 245-267.

Bonson, E. and Flores, F. (2011), "Social media and corporate dialogue: the response of global financial institution", Online Information Review, Vol. 35 No. 1, pp. 34-49.

Bonsón Ponte, E., Carvajal-Trujillo, E., \& Escobar-Rodríguez, T. (2015). Corporate Facebook and stakeholder engagement. Kybernetes, 44(5), 771-787.

Boyd, D. M., \& Ellison, N. B. (2007). Social network sites: Definition, history, and scholarship. Journal of Computer-Mediated Communication, 13(1), 210-230.

Bracket, L., \& Carr, B. (2001). Cyberspace advertising vs. other media: Consumer vs. mature student attitudes (advertising attitudes). Journal of Advertising Research, 41(5), 23-32.

Bravo, R., Montaner, T., \& Pina, J. M. (2012). Corporate brand image of financial institutions: a consumer approach. Journal of Product \& Brand Management, 21(4), 232-245.

Bruhn, M., Schoenmueller, V., \& Schäfer, D. B. (2012). Are Social Media replacing traditional media in terms of brand equity creation? Management Research Review, 35(9), 770-790.

Budd, R. W., Thorp, R. K., \& Donohew, L. (1967). Content analysis of communications.

Bughin, J., Doogan, J., \& Vetvik, O. J. (2010). A new way to measure word-ofmouth marketing. McKinsey Quarterly, 2, 113-116.

Buijzen, M., \& Valkenburg, P. M. (2002). Appeals in television advertising: A content analysis of commercials aimed at children and teenagers. Communications, The European Journal of Communications Research, 27, 349-364.

Bush, A. J., Hair Jr, J. F., \& Bush, R. P. (1983). A content analysis of animation in television advertising. Journal of Advertising, 12(4), 20-41.

Celebi, S. I. (2015). How do motives affect attitudes and behaviors toward internet advertising and Facebook advertising? Computers in Human Behavior, 51, 312-324.

Chauhan, K., \& Pillai, A. (2013). Role of content strategy in social media brand communities: a case of higher education institutes in India. Journal of Product \& Brand Management, 22(1), 40-51. 
Chikandiwa, S.T., Contogiannis, E. and Jembere, E. (2013), "The adoption of social media marketing in South African financial institutions", European Business Review, Vol. 25 No. 4, pp. 365-381.

Cho, C.-H., \& Khang, H. (2006). The state of internet-related research in communications, marketing, and advertising: 1994-2003. Journal of Advertising, 35(3), 143-163.

Constine, J. (2014). Why Is Facebook Page Reach Decreasing? More Competition And Limited Attention TechCrunch. Retrieved from https://techcrunch.com/2014/04/03/the-filtered-feed-problem/

Cooper, D. R., \& Schindler, P. S. (2014). Business research methods (12th ed.): McGraw-Hill.

Costa, M. A., De Almeida, M. I. S., Limongi, R., \& Scalco, P. R. (2013). Me sensibiliza que eu compartilho: o impacto do tipo de postagem sobre o compartilhamento com dados de oito marcas de cerveja no Facebook.

Costa, R. D. (2005). Por um novo conceito de comunidade: redes sociais, comunidades pessoais, inteligência coletiva. Interface-Comunicação, Saúde, Educação, 9, 235-248.

Coyle, J. R., \& Thorson, E. (2001). The effects of progressive levels of interactivity and vividness in web marketing sites. Journal of advertising, 30(3), 65-77.

Crescitelli, E., \& Shimp, T. (2012). Comunicação de marketing: integrando propaganda, promoção e outras formas de divulgação (C. Learning Ed.).

Croft, R. (2013). Blessed are the geeks: An ethnographic study of consumer networks in social media, 2006-2012. Journal of Marketing Management, 29(5-6), 545-561.

Cvijikj, I. P., \& Michahelles, F. (2013). Online engagement factors on Facebook brand pages. Social Network Analysis and Mining, 3(4), 843-861.

Daft, R. L., \& Lengel, R. H. (1986). Organizational information requirements, media richness and structural design. Management science, 32(5), 554571.

Delo, C. (2014, March 6). Brands' organic Facebook reach has crashed since October: Study. Advertising Age. Retrieved from http://adage.com/article/digital/brands-organicfacebook-reach-crashedoctober/292004/

de Vries, L., Gensler, S. and Leeflang, P.S.H. (2012), "Popularity of brand posts on brand fan pages: an investigation of the effects of social media marketing", Journal of Interactive Marketing, Vol. 26 No. 2, pp. 83-91. 
Dootson, P., Beatson, A., \& Drennan, J. (2016). Financial institutions using social media- do consumers perceive value?. International Journal of Bank Marketing, 34(1), 9-36.

Durkin, M., McGowan, P. and Murray, L.(2014), "Perspectives on the potential for social media to improve communication in small business-bank relationships", Entrepreneurship and Innovation, Vol. 15 No. 4, pp. 251264.

Effing, R., \& Spil, T. A. (2016). The social strategy cone: Towards a framework for evaluating social media strategies. International journal of information management, 36(1), 1-8.

Financial Times (2017, Julho 11). Equities. Retrived from https://markets.ft.com/data/equities/tearsheet/summary?s=FB:NSQ

Farshid, M., Plangger, K. and Nel, D. (2011), "The social media faces of major global financial service brands", Journal of Financial Services Marketing, Vol. 16 Nos 3-4, pp. 220-229.

Fortin, D. R., \& Dholakia, R. R. (2005). Interactivity and vividness effects on social presence and involvement with a web-based advertisement. Journal of business research, 58(3), 387-396.

Frey, K. P., \& Eagly, A. H. (1993). Vividness can undermine the persuasiveness of messages. Journal of Personality and Social Psychology, 65(1), 32.

Gao, Q., \& Feng, C. (2016). Branding with social media: User gratifications, usage patterns, and brand message content strategies. Computers in Human Behavior, 63, 868-890.

Gilly, M. C., Graham, J. L., Wolfinbarger, M. F., \& Yale, L. J. (1998). A dyadic study of interpersonal information search. Journal of the Academy of Marketing Science, 26(2), 83-100.

G1 (2016, Agosto 30). Brasil tem mais de 206 milhões de habitantes, segundo o IBGE. Disponível em http://g1.globo.com/economia/noticia/2016/08/brasil-tem-mais-de-206milhoes-de-habitantes-segundo-o-ibge.html

Hanafizadeh, P. (2012). Online Advertising and Promotion: Modern Technologies for Marketing: Modern Technologies for Marketing: IGI Global.

Hennig-Thurau, T., Gwinner, K. P., Walsh, G., \& Gremler, D. D. (2004). Electronic word-of-mouth via consumer-opinion platforms: what motivates consumers to articulate themselves on the internet?. Journal of interactive marketing, 18(1), 38-52. 
Hollebeek, L.D., Glynn, M.S. and Brodie, R.J. (2014), "Consumer brand engagement in social media: conceptualization, scale development and validation", Journal of Interactive Marketing, Vol. 28 No. 2, pp. 149-165.

Jiang, Z., Chan, J., Tan, B. C., \& Chua, W. S. (2010). Effects of interactivity on website involvement and purchase intention. Journal of the Association for Information Systems, 11(1), 34.

Kaplan, A. M., \& Haenlein, M. (2010). Users of the world, unite! The challenges and opportunities of Social Media. Business horizons, 53(1), 59-68.

Karaduman, I. (2013), "The effect of social media on personal branding efforts of top level executives", Procedia - Social and Behavioral Sciences, Vol. 99, November, pp. 465-473.

Katz, E., Blumler, J. G., \& Gurevitch, M. (1973). Uses and gratifications research. The public opinion quarterly, 37(4), 509-523.

Khang, H., Ki, E.-J., \& Ye, L. (2012). Social media research in advertising, communication, marketing, and public relations, 1997-2010. Journalism \& Mass Communication Quarterly, 89(2), 279-298.

Kotler, P., \& Armstrong, G. (1993). Princípios de Marketing (Prentice-Hall Ed.).

Kotler, P., \& Keller, K. L. (2006). Administração de marketing.

Kozinets, R. V. (2002). Can consumers escape the market? Emancipatory illuminations from burning man. Journal of Consumer research, 29(1), 20-38.

Krippendorff, K. (2013). Content analysis: An introduction to its methodology. Sage.

Kumar, V. (2015). Evolution of marketing as a discipline: What has happened and what to look out for. Journal of Marketing, 79(1), 1-9.

Labrecque, L. (2014), "Fostering consumer-brand relationships in social media environments: the role of parasocial interaction", Journal of Interactive Marketing, Vol. 28 No. 2, pp. 134-148.

Laroche, M., Habibi, M.R., Richard, M.O. and Sankaranarayanan, R. (2012), "The effects of social media based brand communities on brand community markers, value creation practices, brand trust and brand loyalty",Computers in Human Behavior, Vol.28 No.5, pp.1755-1767.

Lim, K. H., O'Connor, M. J., \& Remus, W. E. (2005). The impact of presentation media on decision making: does multimedia improve the effectiveness of feedback?. Information \& Management, 42(2), 305-316. 
Liu, J., Li, C., Ji, Y. G., North, M., \& Yang, F. (2017). Like it or not: The Fortune 500's Facebook strategies to generate users' electronic word-of-mouth. Computers in Human Behavior, 73, 605-613.

Liu, Y., \& Shrum, L. J. (2002). What is interactivity and is it always such a good thing? Implications of definition, person, and situation for the influence of interactivity on advertising effectiveness. Journal of advertising, 31(4), 53-64.

Luarn, P., Lin, Y.-F., \& Chiu, Y.-P. (2015). Influence of Facebook brand-page posts on online engagement. Online Information Review, 39(4), 505-519.

Luo, X. (2002). Uses and gratifications theory and e-consumer behaviors: a structural equation modeling study. Journal of Interactive Advertising, 2(2), 34-41.

Macias, W. (2003). A preliminary structural equation model of comprehension and persuasion of interactive advertising brand web sites. Journal of interactive advertising, 3(2), 36-48.

McMillan, S. J., \& Hwang, J. S. (2002). Measures of perceived interactivity: An exploration of the role of direction of communication, user control, and time in shaping perceptions of interactivity. Journal of advertising, 31(3), 29-42.

Kantar Millward Brown (2017). BrandZ Top 100 Global Brands. Retrived from http://www.millwardbrown.com/brandz/top-global-brands/2017

Mitic, M. and Kapoulas, A. (2012), "Understanding the role of social media in bank marketing", Marketing Intelligence and Planning, Vol. 30 No. 7, pp. 668-686.

Muniz, A. M., \& O'guinn, T. C. (2001). Brand community. Journal of consumer research, 27(4), 412-432.

Muntinga, D. G., Moorman, M., \& Smit, E. G. (2011). Introducing COBRAs: Exploring motivations for brand-related social media use. International Journal of advertising, 30(1), 13-46.

Murray, L., Durkin, M., Worthington, S. and Clark, V. (2014), "On the potential for Twitter to add value in retail bank relationships", Journal of Financial Services Marketing, Vol. 19 No. 4, pp. 277-290.

Nepomuceno, M.V., \& Porto, J. B.(2010). Human values and attitudes toward bank services in Brazil. International Journal of Bank Marketing, 28(3), 168-192.

Neumeier, M. (2009). Zag: A Estratégia no 1 das Marcas de Sucesso: Bookman Editora. 
Nisar, T. M., \& Whitehead, C. (2016). Brand interactions and social media: Enhancing user loyalty through social networking sites. Computers in Human Behavior, 62, 743-753.

Nisbett, R. E., \& Ross, L. (1980). Human inference strategies and shortcomings of social judgment. Englewood Cliffs, N.J.: Prentice-Hall

Nov, O. (2007). What motivates wikipedians?. Communications of the ACM, $50(11), 60-64$.

Park, N., Kee, K. F., \& Valenzuela, S. (2009). Being immersed in social networking environment: Facebook groups, uses and gratifications, and social outcomes. CyberPsychology \& Behavior, 12(6), 729-733.

Pereira, R. L. V. (2015, 31 de Agosto). Setor de serviços encolhe pela 1ạ vez desde 1990, estimam economistas. Folha de São Paulo. Disponível em

http://www1.folha.uol.com.br/mercado/2015/08/1675715-setor-de-servicosencolhe-pela-1-vez-desde-1990-estimam-economistas.shtml

PopulationPyramid. (2017). Population Pyramids of the World from 1950 to 2100. Retrived from https://www.populationpyramid.net/world/2017/

Porter, C. E. (2004). A typology of virtual communities: A multi-disciplinary foundation for future research. Journal of Computer-Mediated Communication, 10(1), 00-00.

Rafaeli, S. (1988). From new media to communication. Sage annual review of communication research: Advancing communication science, 16, 110134.

Ralphs, M. (2011). Built in or bolt on: Why social currency is essential to social media marketing. Journal of Direct, Data and Digital Marketing Practice, 12(3), 211-215.

Rokka, J., Karlsson, K. and Tienari, J. (2014), "Balancing acts: managing employees and reputation in social media", Journal of Marketing Management, Vol.30 Nos 7-8, pp.802-827.

Rosenthal, B., \& Brito, E. P. (2017). How virtual brand community traces may increase fan engagement in brand pages. Business Horizons, 60(3), 375-384.

Sabate, F., Berbegal-Mirabent, J., Cañabate, A., \& Lebherz, P. R. (2014).

Factors influencing popularity of branded content in Facebook fan pages. European Management Journal, 32(6), 1001-1011. 
Saxena, A., \& Khanna, U. (2013). Advertising on social network sites: A structural equation modelling approach. Vision: The Journal of Business Perspective, 17(1), 17-25.

Sayre, S. (1992). Content analysis as a tool for consumer research. Journal of Consumer Marketing, 9(1), 15-25.

Scarpi, D. (2010), "Does size matter? An examination of small and large webbased brand communities", Journal of Interactive Marketing, Vol. 24 No. 1, pp. 14-21.

Schau, H. J., Muñiz Jr, A. M., \& Arnould, E. J. (2009). How brand community practices create value. Journal of marketing, 73(5), 30-51.

Schumann, D. W., Artis, A., \& Rivera, R. (2001). The future of interactive advertising viewed through an IMC lens. Journal of Interactive Advertising, 1(2), 43-55.

Schramm, W., \& Roberts, D. F. (1971). The process and effects of mass communication.

Schweidel, D. A., \& Moe, W. W. (2014). Listening in on social media: a joint model of sentiment and venue format choice. Journal of Marketing Research, 51(4), 387-402.

Shannon, C. E. (1948). A mathematical theory of communication, Part I, Part II. Bell Syst. Tech. J., 27, 623-656.

Shi, S., Chen, Y., \& Chow, W. S. (2016). Key values driving continued interaction on brand pages in social media: An examination across genders. Computers in Human Behavior, 62, 578-589.

Sicilia, M., Ruiz, S., \& Munuera, J. L. (2005). Effects of interactivity in a web site: The moderating effect of need for cognition. Journal of advertising, 34(3), 31-44.

Smith, A., Fischer, E. and Yongjian, C. (2012), "How does brand-related usergenerated content differ across YouTube, Facebook, and Twitter?", Journal of Interactive Marketing, Vol. 26 No. 2, pp. 102-113.

Smith, C. P. Content analysis and narrative analysis in REIS, Harry T.; JUDD, Charles M. (Ed.).(2000). Handbook of research methods in social and personality psychology. Cambridge University Press, p. 313-335.

Smith, S. M., \& Shaffer, D. R. (2000). Vividness can undermine or enhance message processing: The moderating role of vividness congruency. Personality and Social Psychology Bulletin, 26(7), 769-779. 
Sorescu, A., Frambach, R.T., Singh, J., Rangaswamy, A. and Bridges, C. (2011), "Innovations in retail business models", Journal of Retailing, Vol. S87 No. 1, pp. S3-S16.

Statista. (2017). Number of monthly active Facebook users worldwide as of 1 st quarter 2017 (in millions). Disponível em http://www.statista.com/statistics/264810/number-of-monthly-activefacebook-users-worldwide/

Steuer, J. (1992). Defining virtual reality: Dimensions determining telepresence. Journal of communication, 42(4), 73-93.Stevenson, E. D. (2010). Advertising on Facebook isn't part of a social media strategy. New Media Age, 15-15.

Stevenson, E. (2010, October 28). Advertising on Facebook isn't part of a social media strategy. New Media Age, p.15

Stewart, D. W., \& Pavlou, P. A. (2002). From consumer response to active consumer: Measuring the effectiveness of interactive media. Journal of the Academy of Marketing Science, 30(4), 376-396.

Subramani, M. R., \& Rajagopalan, B. (2003). Knowledge-sharing and influence in online social networks via viral marketing. Communications of the ACM, 46(12), 300-307.

Sumares, G. (2016, Abril 27). Facebook tem mais de 100 milhões de usuários brasileiros. Disponível em https://olhardigital.com.br/noticia/facebooktem-mais-de-100-milhoes-de-usuarios-brasileiros/57706

Sundar, S. S., \& Kim, J. (2005). Interactivity and persuasion: Influencing attitudes with information and involvement. Journal of interactive advertising, 5(2), 5-18.

Swani, K., Milne, G. R., Brown, B. P., Assaf, A. G., \& Donthu, N. (2017). What messages to post? Evaluating the popularity of social media communications in business versus consumer markets. Industrial Marketing Management, 62, 77-87.

Tafesse, W. (2015). Content strategies and audience response on Facebook brand pages. Marketing Intelligence \& Planning, 33(6), 927-943.

Taylor, S. E., \& Thompson, S. C. (1982). Stalking the elusive" vividness" effect. Psychological review, 89(2), 155.

Tomasello, T. K., Lee, Y., \& Baer, A. P. (2009). 'New media'research publication trends and outlets in communication, 1990-2006. new media \& society. 
Trainor, K.J., Andzulis, J.M., Rapp, A. and Agnihotri, R. (2014), "Social media technology usage and consumer relationship performance: a capabilitiesbased examination of social CRM", Journal of Business Research, Vol. 67 No. 6, pp. 1201-1208.

Tsimonis, G., \& Dimitriadis, S. (2014). Brand strategies in social media. Marketing Intelligence \& Planning, 32(3), 328-344.

Van Der Heide, B., D'Angelo, J. D., \& Schumaker, E. M. (2012). The effects of verbal versus photographic self-presentation on impression formation in Facebook. Journal of Communication, 62(1), 98-116.

Waller, D. (2016, March 22). Build a brand via social media? You're having a laugh. The Times, p.47

Wang, H., \& Nadda, V. (2015). A Revisit of the Concept of Interactivity and its Dimensions. International Journal of Online Marketing (IJOM), 5(4), 84109.

Wang, S. S., Moon, S. I., Kwon, K. H., Evans, C. A., \& Stefanone, M. A. (2010). Face off: Implications of visual cues on initiating friendship on Facebook. Computers in Human Behavior, 26(2), 226-234.

Weinberg, B. D., de Ruyter, K., Dellarocas, C., Buck, M., \& Keeling, D. I. (2013). Destination social business: Exploring an organization's journey with social media, collaborative community and expressive individuality. Journal of interactive marketing, 27(4), 299-310.

Westbrook, R. A. (1987). Product/consumption-based affective responses and postpurchase processes. Journal of marketing research, 258-270.

Wu, G. (2005). The mediating role of perceived interactivity in the effect of actual interactivity on attitude toward the website. Journal of Interactive advertising, 5(2), 29-39.

Xu, H., Oh, L. B., \& Teo, H. H. (2009). Perceived effectiveness of text vs. multimedia location-based advertising messaging. International Journal of Mobile Communications, 7(2), 154-177.

Zarrella, D. (2009). The social media marketing book: " O'Reilly Media, Inc.". 